US Army Corps

of Engineers ${ }_{\circledast}$

Engineer Research and

Development Center

Installation Technology Transfer Program

Performance Testing of a Novel Dry-Fog Mold Remediation and Prevention Process

Shane D. Hirschi and Dale L. Herron

August 2018

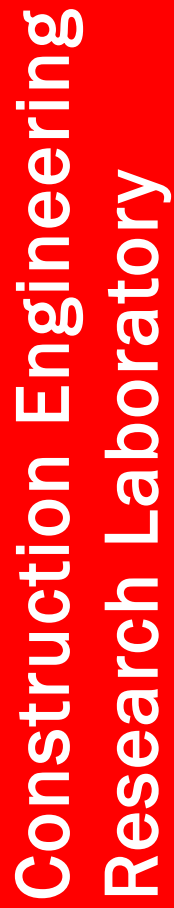

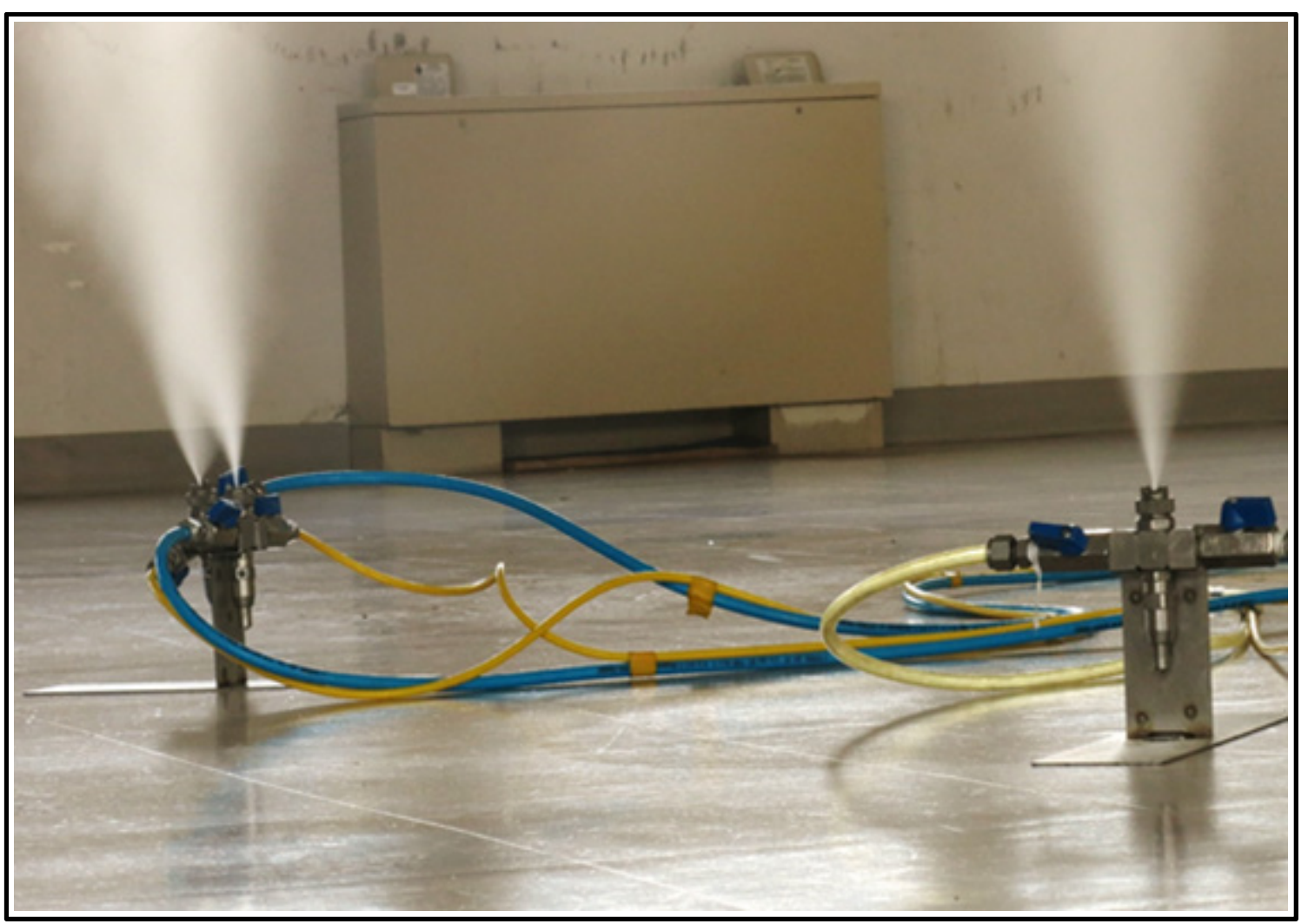


The U.S. Army Engineer Research and Development Center (ERDC) solves the nation's toughest engineering and environmental challenges. ERDC develops innovative solutions in civil and military engineering, geospatial sciences, water resources, and environmental sciences for the Army, the Department of Defense, civilian agencies, and our nation's public good. Find out more at www.erdc.usace.army.mil.

To search for other technical reports published by ERDC, visit the ERDC online library at http://acwc.sdp.sirsi.net/client/default. 


\title{
Performance Testing of a Novel Dry-Fog Mold Remediation and Prevention Process
}

\author{
Shane D. Hirschi and Dale L. Herron \\ U.S. Army Engineer Research and Development Center (ERDC) \\ Construction Engineering Research Laboratory (CERL) \\ 2902 Newmark Dr. \\ Champaign, IL 61824
}

Final Report

Approved for public release; distribution is unlimited.

Prepared for Assistant Chief of Staff for Installation Management, Washington, DC 20310-0600

Under ITTP, "Performance Testing of a Novel Dry-Fog Mold Remediation and Prevention Process" 


\section{Abstract}

Mold is an ongoing problem for Army installations and contingency basing locations. This work was undertaken to demonstrate the effectiveness of a two-step dry-fog mold remediation process technology to remove mold spores and provide long-term mold prevention in two buildings at Fort Campbell, KY. Treating each test building took 5 to 6 hours and included: mobilization, air and surface sampling before and after the application, and demobilization. This work concluded that the dry-fog technology provides rapid and quantifiable improvements to indoor air quality, and reduces exposure of personnel to harmful chemicals resulting from current mold remediation practices. Results indicated that the dry-fog technology could potentially support mold remediation needs resulting from indoor air quality maintenance and from natural hazards. Current rough estimates for application of the dry-fog technology are approximately $\$ 1.00 / \mathrm{sq} \mathrm{ft}$. Early project results were shared with Region IV of the Federal Emergency Management Agency (FEMA) and the Huntington District of the U.S. Army's Corps of Engineers.

DISCLAIMER: The contents of this report are not to be used for advertising, publication, or promotional purposes. Citation of trade names does not constitute an official endorsement or approval of the use of such commercial products. All product names and trademarks cited are the property of their respective owners. The findings of this report are not to be construed as an official Department of the Army position unless so designated by other authorized documents. 


\section{Contents}

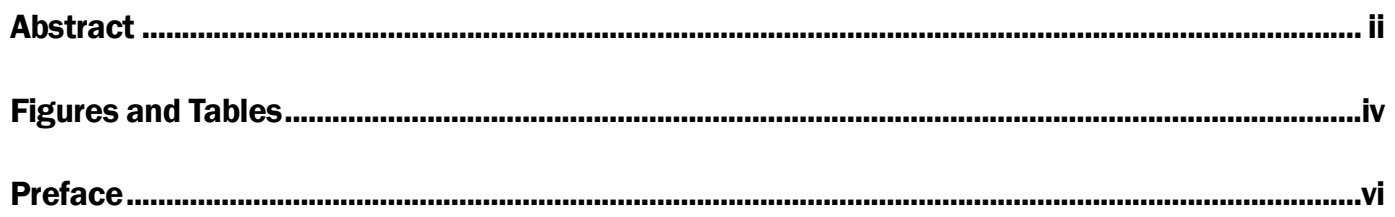

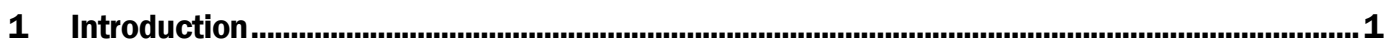

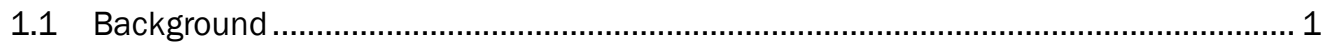

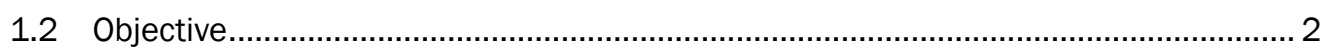

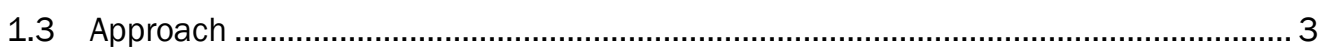

1.4 Mode of technology transfer ................................................................................. 4

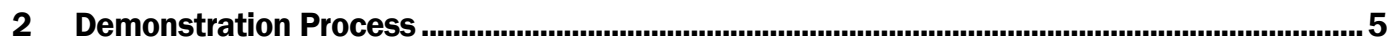

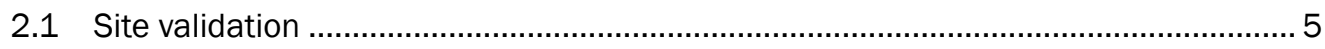

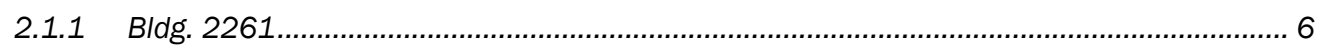

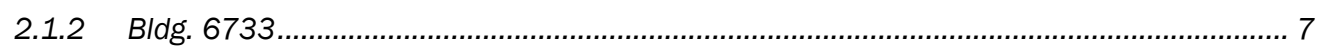

2.2 Baseline/background sampling and analysis ..................................................... 9

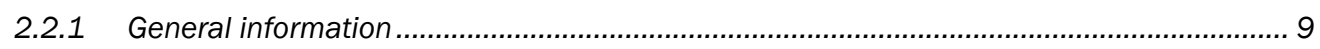

2.2.2 Background sampling for this demonstration project.................................................... 11

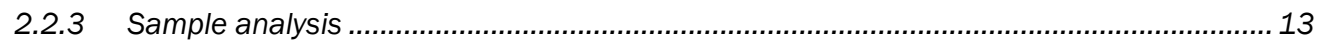

2.3 Two-step dry-fog application ..................................................................... 13

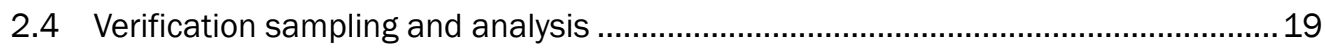

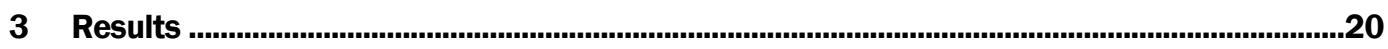

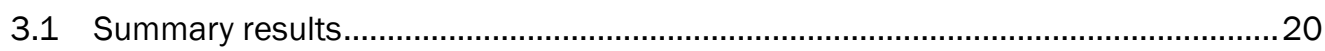

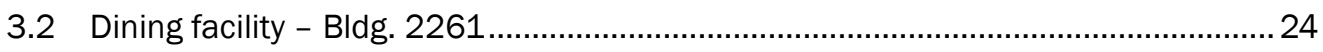

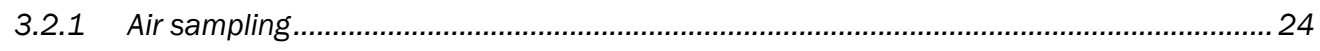

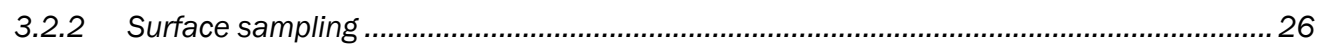

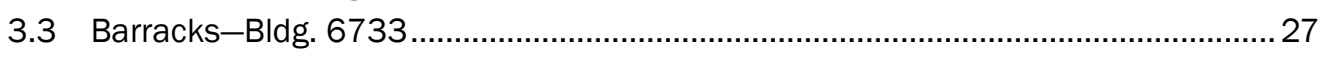

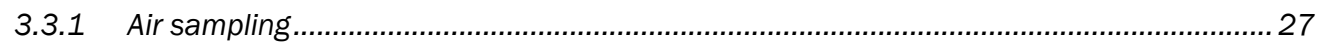

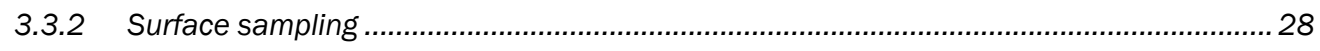

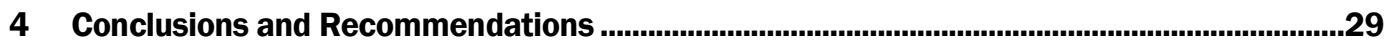

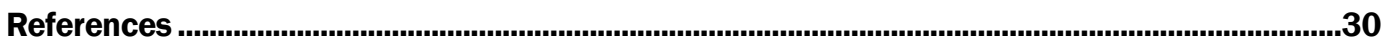

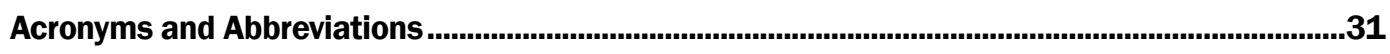

Appendix A: Material Safety Data Sheets for INSTAPure and EVERPure .....................................32

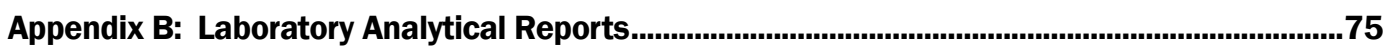

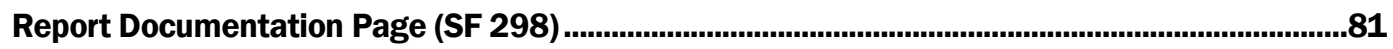




\section{Figures and Tables}

\section{Figures}

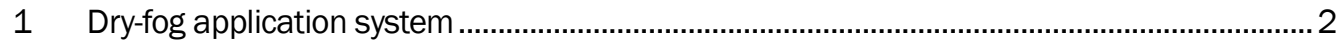

2 Fort Campbell cantonment area showing demonstration locations ...................................... 5

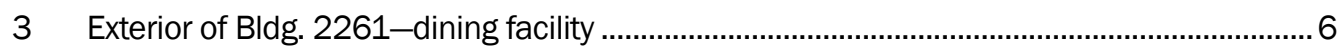

$4 \quad$ Kitchen area inside Bldg. 2261..................................................................................... 6

$5 \quad$ Dining area inside Bldg. 2261 …....................................................................................

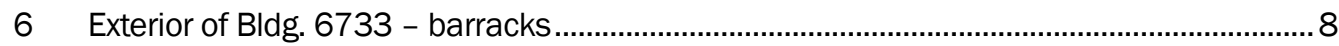

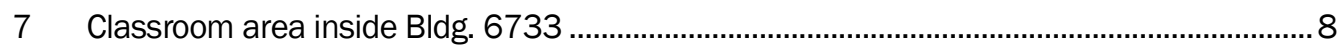

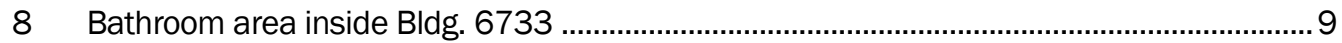

9 Sampling locations at Bldgs. 2261 and 6733 (not to scale) .............................................12

10 Air and surface sampling equipment.................................................................................12

11 Equipment to apply the dry-fog treatment ..............................................................................14

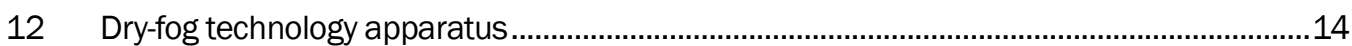

13 Dry-fog being applied via spray nozzle in Bldg. 2261 ……................................................16

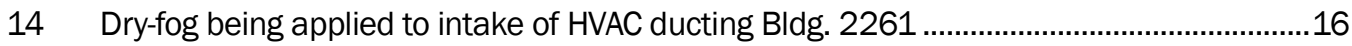

15 Dry-fog being applied via spray nozzles in Bldg. 6733......................................................16

16 Positive pressure at various points within Bldg. 2261 ...........................................................17

17 Dry-fog accumulation in kitchen area within Bldg. 2261....................................................17

18 Indicator strips signify treatment (i.e., white to black) ...................................................

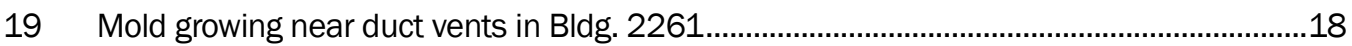

20 Air and surface sampling...................................................................................................19

21 Bldg. 2261 Stachybotrys/Chaetomium vs. Stachybotrys/Chaetomium

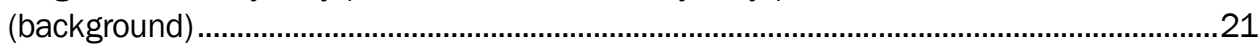

22 Bldg. 2261-Total Spores vs. Total Spores (background) …………………......................21

23 Bldg. 2261-Hyphal Fragments vs. Hyphal Fragments (background).................................22

24 Bldg. 6733-Stachybotrys/Chaetomium vs. Stachybotrys/Chaetocmium

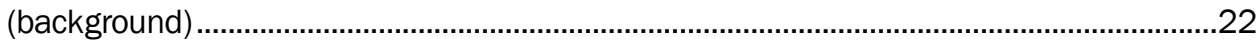

25 Bldg. 6733-Total Spores vs. Total Spores (background) ....................................................23

26 Bldg. 6733-Hyphal Fragments vs. Hyphal Fragments (background).................................23

27 Wall surface moisture content of 100\% near Sample Location \#4 ....................................25

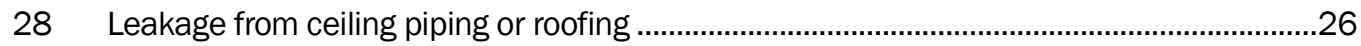

\section{Tables}

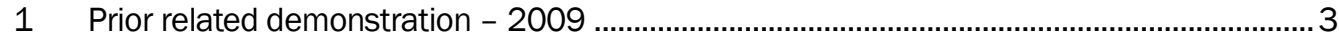

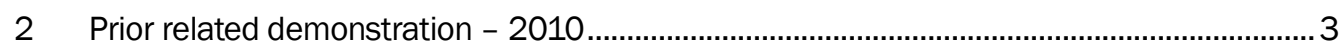

3 U.S. national outdoor average for April.................................................................................10

4 U.S. national outdoor average for July .................................................................................1 11 
$5 \quad$ U.S. national outdoor average for October ........................................................................11

6 Annual outdoor average for Illinois ...............................................................................11

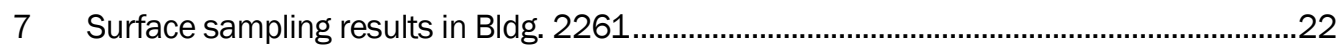

8 Surface sampling results in Bldg. 6733

9 Air sampling results (\#spores/m³) for Bldg. 2261 ...............................................................24

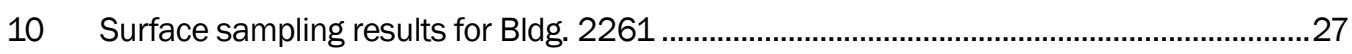

11 Air sampling results (\#spores/m³) for Bldg. 6733 .............................................................2

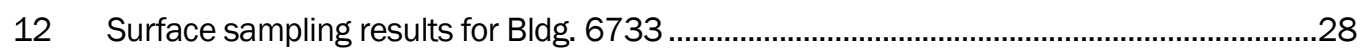




\section{Preface}

This study was conducted for the Assistant Chief of Staff for Installation Management (ACSIM) under the Installation Technology Transition Program (ITTP), project element "Performance Testing of a Novel Dry-Fog Mold Remediation and Prevention Process.” The technical monitor was Natalie Myers, CEERD-CNN.

The work was performed by the Energy Branch (CFE) of the Facilities Division (CF), U.S. Army Engineer Research and Development Center, Construction Engineering Research Laboratory (ERDC-CERL). Special thanks is owed to the personnel from Fort Campbell, $\mathrm{KY}$ for their collaboration, knowledge, experience, and field support. At the time of publication, Giselle Rodriguez was Chief, CEERD-CFE; Donald K. Hicks was Chief, CEERD-CF; and Kurt Kinnevan, CEERD-CZT was the Technical Director for Facilities. The Deputy Director of ERDC-CERL was Dr. Kirankumar V. Topudurti and the Director was Dr. Lance D. Hansen.

COL Ivan P. Beckman was Commander of ERDC, and Dr. David W. Pittman was the Director. 


\section{Introduction}

\subsection{Background}

Mold is a fungus that can grow on virtually any substance, provided moisture is present. Without treatment or preventive measures, mold can damage buildings and negatively affect the health of building occupants. Mold is typically removed and remediated when it becomes visually apparent (when it "looks bad"). Unfortunately, common mold removal practices address only the visual evidence of mold; they do not remove or remediate the mold spores.

In fact, air and surface sampling are required to test whether mold spores have been completely removed. However, since there are no indoor air quality regulations/limitations for mold spores, it is difficult to enforce and/or provide rationale to justify mold treatment based on indoor air quality. This question can only be verified and resolved through sample collection and analysis via an approved laboratory. Interpreting laboratory results for mold can be difficult for several reasons. First, there are no set maximum exposure limits (MELs) for airborne indoor mold concentrations. Setting limits is a difficult matter for many reasons. To begin with, there are limited data on the relationship between exposure and human response. Furthermore, an MEL would have to account for variation in sampling techniques; sensitivity to microbial exposures across the human population; and the vast number of varying types of mold and other biological pollutants within the indoor environment (NAVFAC 2011).

The current preferred process for mold eradication is to control and eliminate the source of moisture that precipitates mold growth (USAPHC 2002). However, in U.S. Department of Defense (DoD) installations, it can be difficult to implement this common solution. In most, if not all, realworld operational settings, occupants often adjust system specific heating, ventilation, and air-conditioning (HVAC) set points, and open or close such physical controls as windows, doors, etc. to enhance their comfort without regard for how those actions affect the building's propensity for mold growth. This, combined with outstanding maintenance needs on systems that control moisture in buildings, are reoccurring issues on military installations that promote mold growth. Consequently, mold continues to 
be an ongoing problem for Army installations and contingency basing locations (Vavrin and Stein 2015). The problem is further compounded by the fact that current mold remediation technologies are labor intensive, and that workers must wear various levels of personal protective equipment (PPE) during mold removal and prevention processes. These specific requirements are detailed in UFGS-02 8500.00 20, Mold Remediation (NAVFAC 2011).

In this work, Fort Campbell, KY, and the U.S. Army Engineer Research and Development Center (ERDC) partnered with the Army Office of the Assistant Chief of Staff for Installation Management's (OACSIM) Installation Technology Transfer Program (ITTP) to demonstrate the effectiveness of the two-step dry-fog mold remediation process technology developed by Pure Maintenance LLC, a commercial partner that owns the patented treatment technology. The dry-fog demonstration took place at two buildings at Fort Campbell, KY: a vacant dining facility, and a dormant barracks administration section that included classrooms, restrooms, and offices.

\subsection{Objective}

The objective of this ITTP demonstration was to conduct independent performance testing of the novel dry-fog mold remediation and prevention process to determine the effectiveness of the treatment process at eliminating mold and preventing regrowth at military installations and contingency basing locations. Specific technical objectives were to:

1. Demonstrate the dry-fog process via the $2^{\text {nd }}$ generation application system (Figure 1) in two buildings at Fort Campbell, KY.

2. Determine the efficacy and performance (via sampling and analysis) of the dry-fog process.

3. Verify initial remediation impact(s) and non-reoccurrence of mold/mildew over a test period of 6 months (via sampling and analysis).

Figure 1. Dry-fog application system.

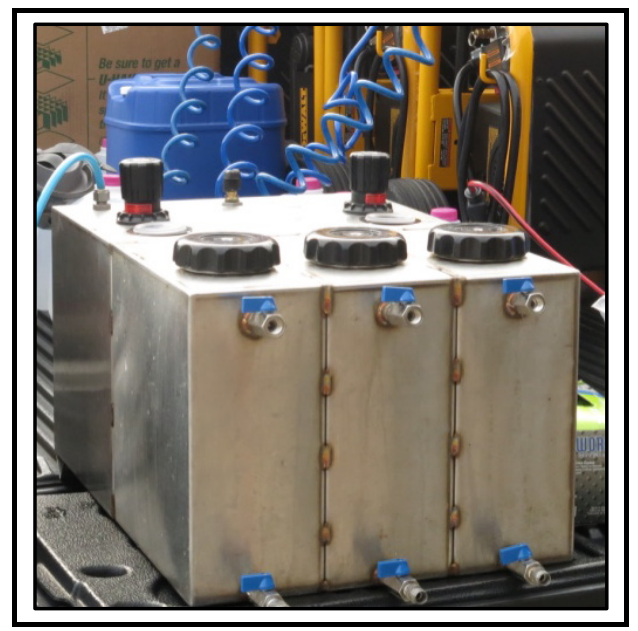




\subsection{Approach}

This project is related to two prior ITTP studies/demonstrations performed separately in Fiscal Year 2009 (FYo9) $^{*}$ and FY10 (Stephenson, Lattimore, and Torrey 2011). Both these projects were performed at Fort Polk, LA. The data in Tables 1 and 2, respectively, briefly summarize the FYo9 and FY10 studies/demonstrations.

Table 1. Prior related demonstration - 2009.

\begin{tabular}{|l|l|}
\hline Parameter & \multicolumn{1}{|c|}{ Data } \\
\hline $\begin{array}{l}\text { Year of } \\
\text { Study }\end{array}$ & 2009 \\
\hline Study & $\begin{array}{l}\text { Demonstration of Mold Assessment and Removal Technologies at Fort Polk, LA } \\
\text { (L.D. Stephenson et al. 2009) }\end{array}$ \\
\hline $\begin{array}{l}\text { Approach/ } \\
\text { Objective }\end{array}$ & Determine the mold burden, eradicate mold, and mitigate its recurrence \\
\hline Findings & $\begin{array}{l}\text { Dry ice was successfully tested on concrete and concrete block surfaces, along } \\
\text { with biocide protectants applied post-removal } \\
\text { Although dry ice was shown to be a successful multi-step mold removal process, } \\
\text { a simple mold removal and long-term prevention strategy is desired }\end{array}$ \\
\hline
\end{tabular}

Table 2. Prior related demonstration - 2010.

\begin{tabular}{|l|l|}
\hline Parameter & \multicolumn{1}{|c|}{ Data } \\
\hline $\begin{array}{l}\text { Year of } \\
\text { Study }\end{array}$ & 2010 \\
\hline Study & $\begin{array}{l}\text { Prevention of Toxic Molds in Army Facilities Using Surface-Applied Biocides (L.D. } \\
\text { Stephenson, J.L. Lattimore, and K.M. Torrey 2011) }\end{array}$ \\
\hline $\begin{array}{l}\text { Approach/ } \\
\text { Objective }\end{array}$ & $\begin{array}{l}\text { Evaluate the efficacy of a two-step mold removal process, which involves } \\
\text { application of biocidal “eradicants" to remove mold from a variety of surfaces, } \\
\text { followed by application of biocidal "protectants" to prevent recurrence of mold }\end{array}$ \\
\hline $\begin{array}{l}\text { Two best tests for quantifying potential for growth, existing mold, mold removal } \\
\text { and long-term efficacy of protectants are: (1) viable swab test and (2) viable } \\
\text { airborne spore count } \\
\text { Best performing eradicants were: Sporicidin } \\
\text { Shockwave (a phenolic-based product) and } \\
\text { Best performing antimicrobial protectants were Fosters 40-20 and Indoor Air } \\
\text { Quality (IAQ) } 6000 \\
\text { Full body coverage, rubber gloves, eye protection, and dust filter should be used } \\
\text { during application of both eradicants and protectants } \\
\text { American Society for Testing and Materials (ASTM) D5590 successfully predicted the } \\
\text { long-term efficacy of protectants to mitigate recurrence of mold growth at Fort Polk. } \\
\text { The 4-week accelerated test is suggested as a way to quantify relative efficacy } \\
\text { among newly emerging protectants and can be used for screening purposes }\end{array}$ \\
\hline
\end{tabular}

* L. D. Stephenson, J. L. Lattimore, Ashok Kumar, and Raymond E. Patenaude. 2009. Demonstration of Mold Assessment and Removal Technologies at Fort Polk, Louisiana. Draft Technical Report. Champaign, IL: Engineer Research and Development Center, Construction Engineering Research Laboratory (ERDC-CERL). 
This project involves a demonstration and evaluation of the short term and long-term effects of a dry-fog technology. To demonstrate/validate this technology, the researcher partners:

1. Identified two buildings suitable with existing mold problems at Fort Campbell that are suitable for use in the demonstration project.

2. Conducted pretreatment air and surface sampling in the demonstration buildings to determine existing mold levels.

3. Treated the designated areas within the buildings using the dry-fog process.

4. Sampled immediately after treatment to determine the initial effects of the treatment process.

5. Performed additional sampling after 1 month, 3 months, and 6 months following treatment to determine the long-term effects of the treatment.

6. Performed analyses to determine the efficacy of the dry-fog treatment technology.

\subsection{Mode of technology transfer}

The project team delivered the following technology transfer elements and activities during project execution:

- A Public Works Digest article (Hirschi and Herron 2017) was submitted for publishing.

- The Huntington, West Virginia District of the Corp of Engineers and Region IV of the Federal Emergency Management Agency (FEMA) were briefed on early project results via telecom.

- A U.S. Army Corps of Engineers (USACE) Engineering and Construction webinar was provided.

- A one-page project summary delivered to the OACSIM Program Management Office (PMO).

- A webinar with all 10 Regions and FEMA Headquarters is pending. 


\section{Demonstration Process}

This project team, made up of individuals from Fort Campbell, KY, the Engineer Research and Development Center, Construction Engineering Research Laboratory (ERDC-CERL), and Pure Maintenance LLC performed site validation, completed baseline/background sampling and analysis, executed the treatment process using the two-step dry-fog technology and performed verification sampling and analysis to demonstrate the two-step dry-fog technology.

\subsection{Site validation}

Before initiation of any onsite activities, the project team held a kick-off meeting via telecon to identify the potential facilities and associated infrastructure at Fort Campbell, KY. On 9 March 2017, a site visit was held to facilitate a walk-through of the two demonstration locations, Bldg. 2261 (Dining Facility) and Bldg. 6733 (Barracks). Figure 2 shows their locations within the cantonment area of Fort Campbell. Both of these buildings were vacant and determined to be good candidates for the demonstration.

Figure 2. Fort Campbell cantonment area showing demonstration locations.

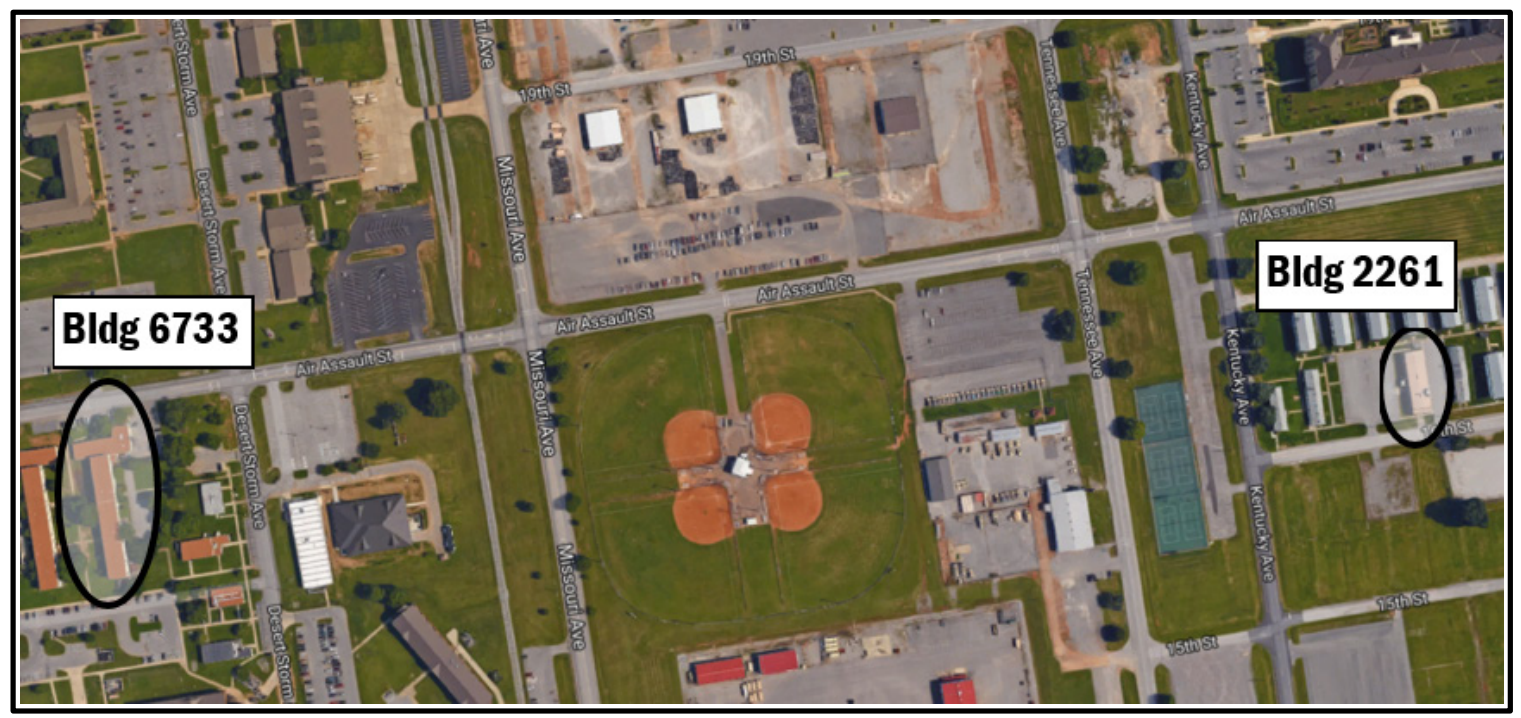

Source: Map Data $2017^{\odot}$ Google. 


\subsubsection{Bldg. 2261}

Bldg. 2261 (Figure 3) is a vacant dining facility with an interior area of $4000 \mathrm{sq} f \mathrm{ft}$, of which approximately $3700 \mathrm{sq} \mathrm{ft}$ were treated. Figures 4 and 5 show the existing conditions inside the facility. Mold was visible on most all surfaces to varying degrees.

Figure 3. Exterior of BIdg. 2261-dining facility.

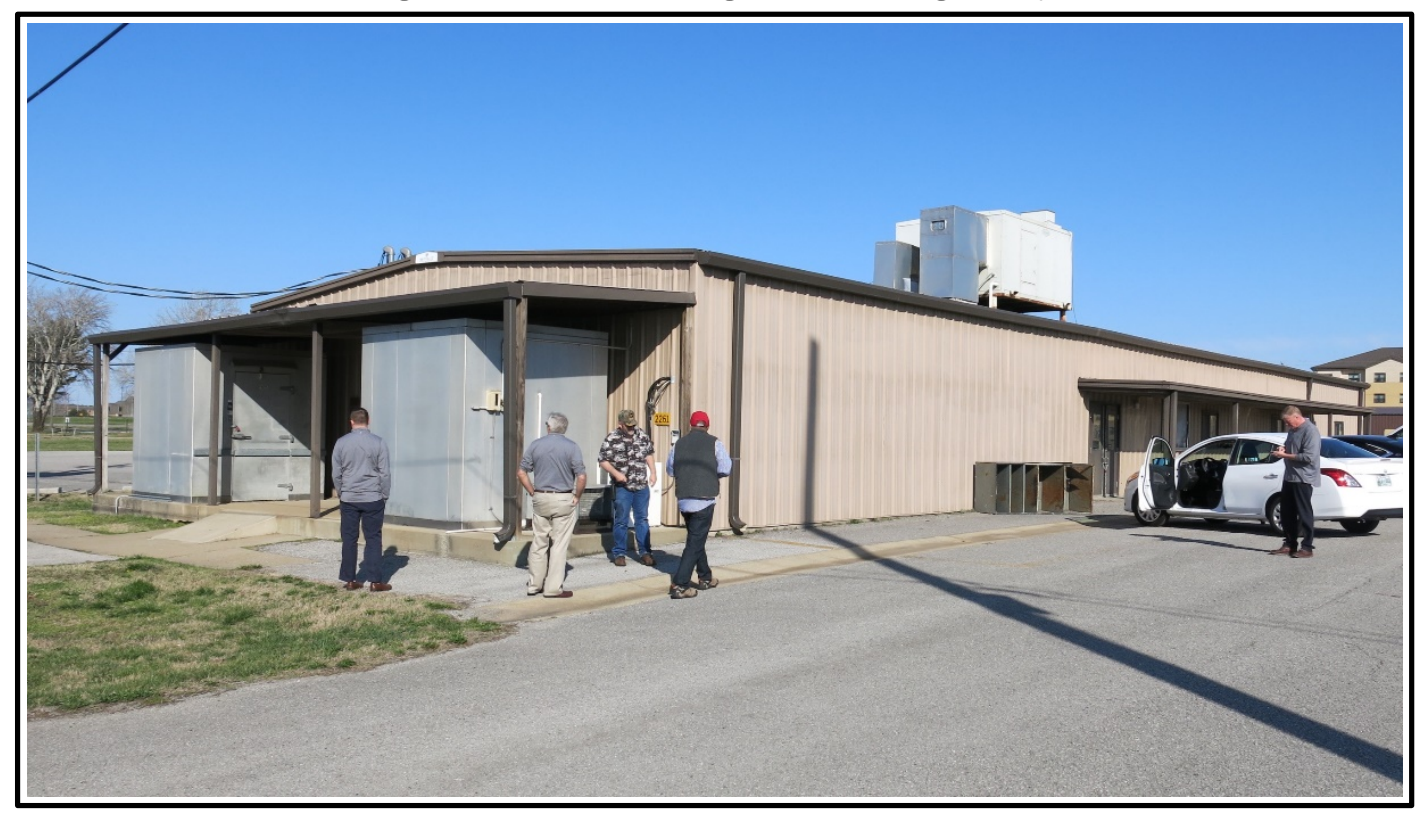

Figure 4. Kitchen area inside Bldg. 2261.

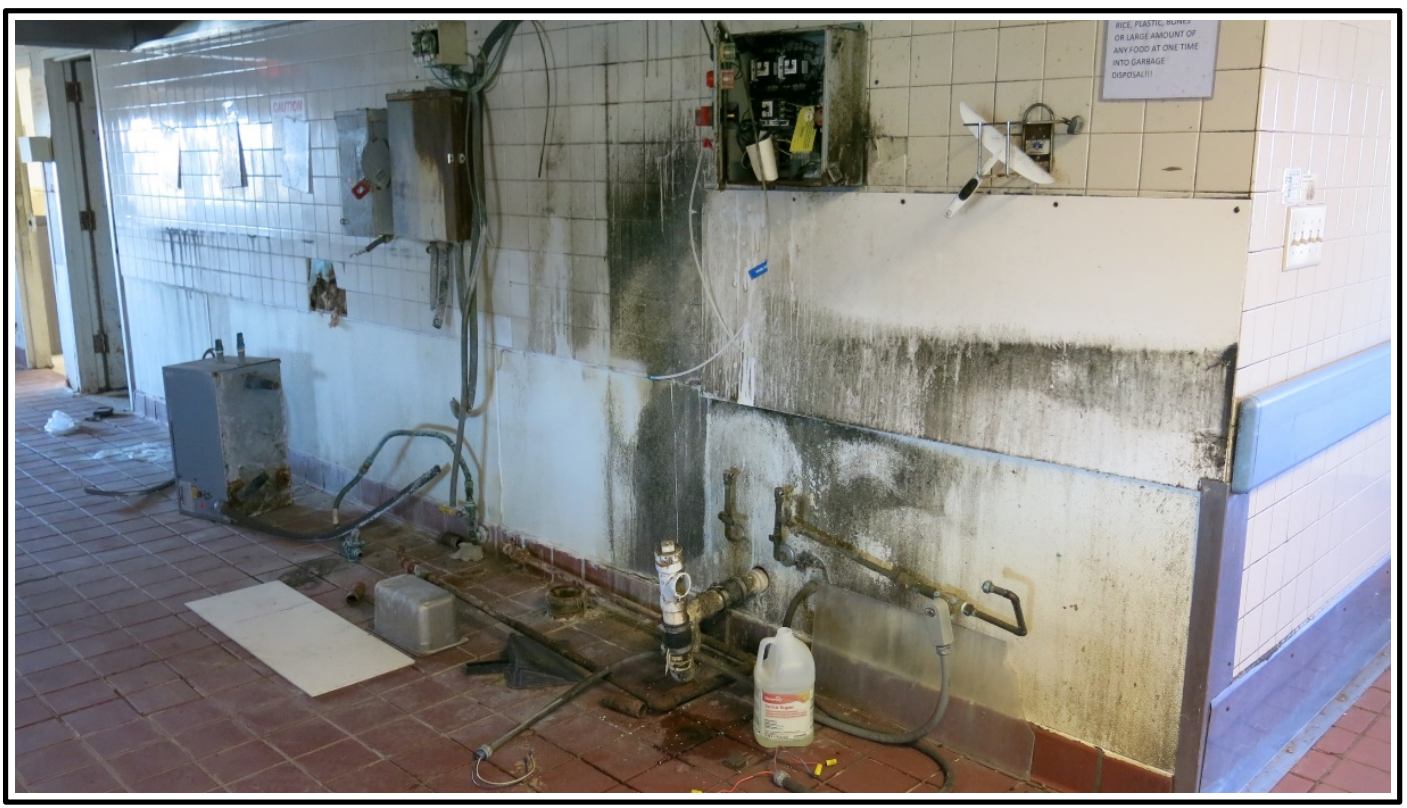


Figure 5. Dining area inside Bldg. 2261.

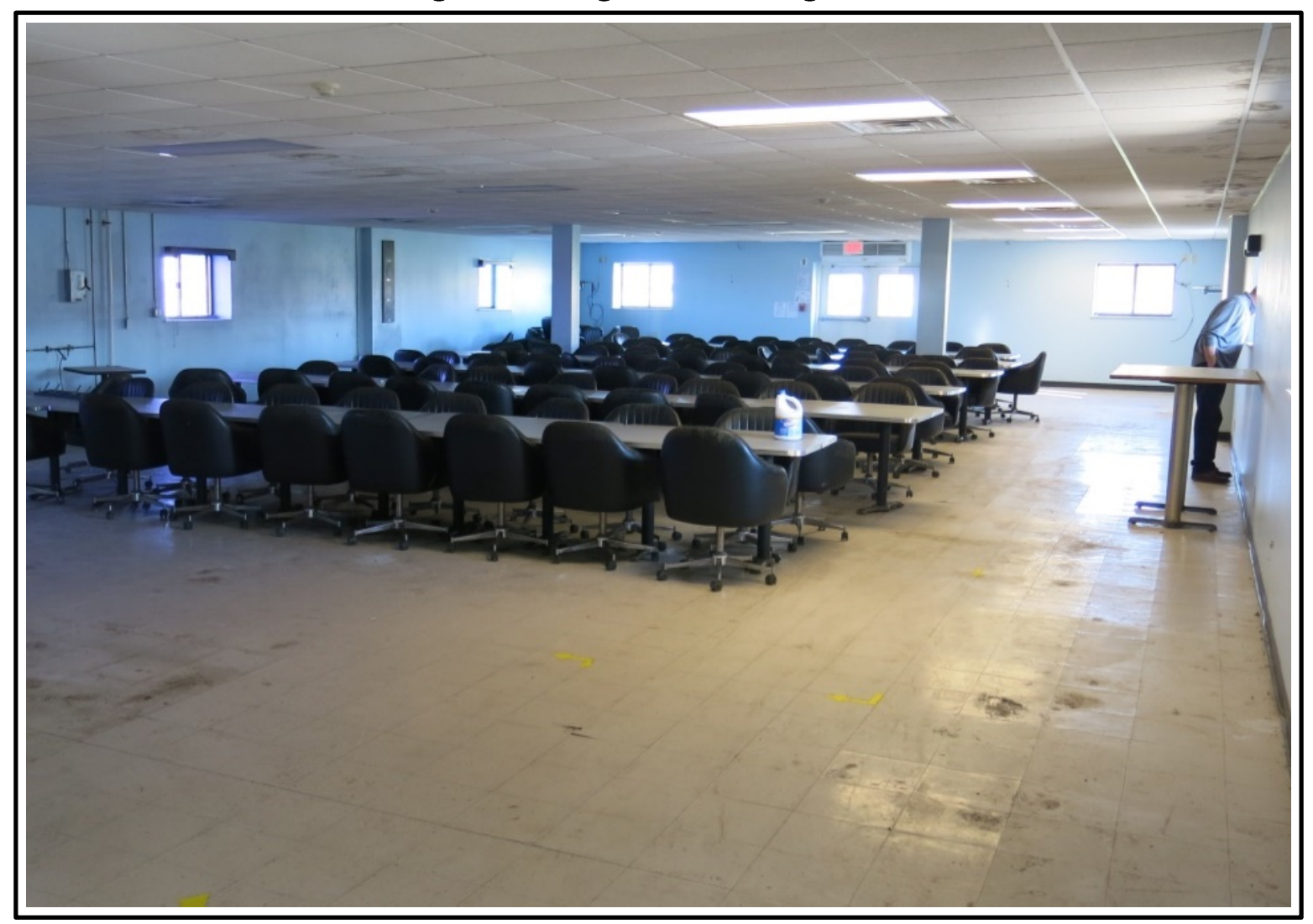

\subsubsection{Bldg. 6733}

Bldg. 6733 (Figure 6) is a vacant hammerhead style barracks facility with interior area of $38,000 \mathrm{sq} \mathrm{ft}$, of which approximately $2800 \mathrm{sq} \mathrm{ft}$ were treated. Only the administrative area of the first floor (i.e., classroom, offices, and restrooms) were included in this demonstration. Figures 7 and 8 show the amounts of mold visible on the wall surfaces.

These buildings were chosen because they were vacant, and because they were known to have high levels of mold. Given the short (8-month) demonstration period, vacant buildings were selected to make it easier to schedule treatments and to control building ingress and egress. However, the absence of personnel and functioning HVAC systems made it difficult to ensure constant environmental/occupational conditions. Outside temperatures had an additional impact on the variables of interest within the two buildings. 
Figure 6. Exterior of Bldg. 6733 - barracks.

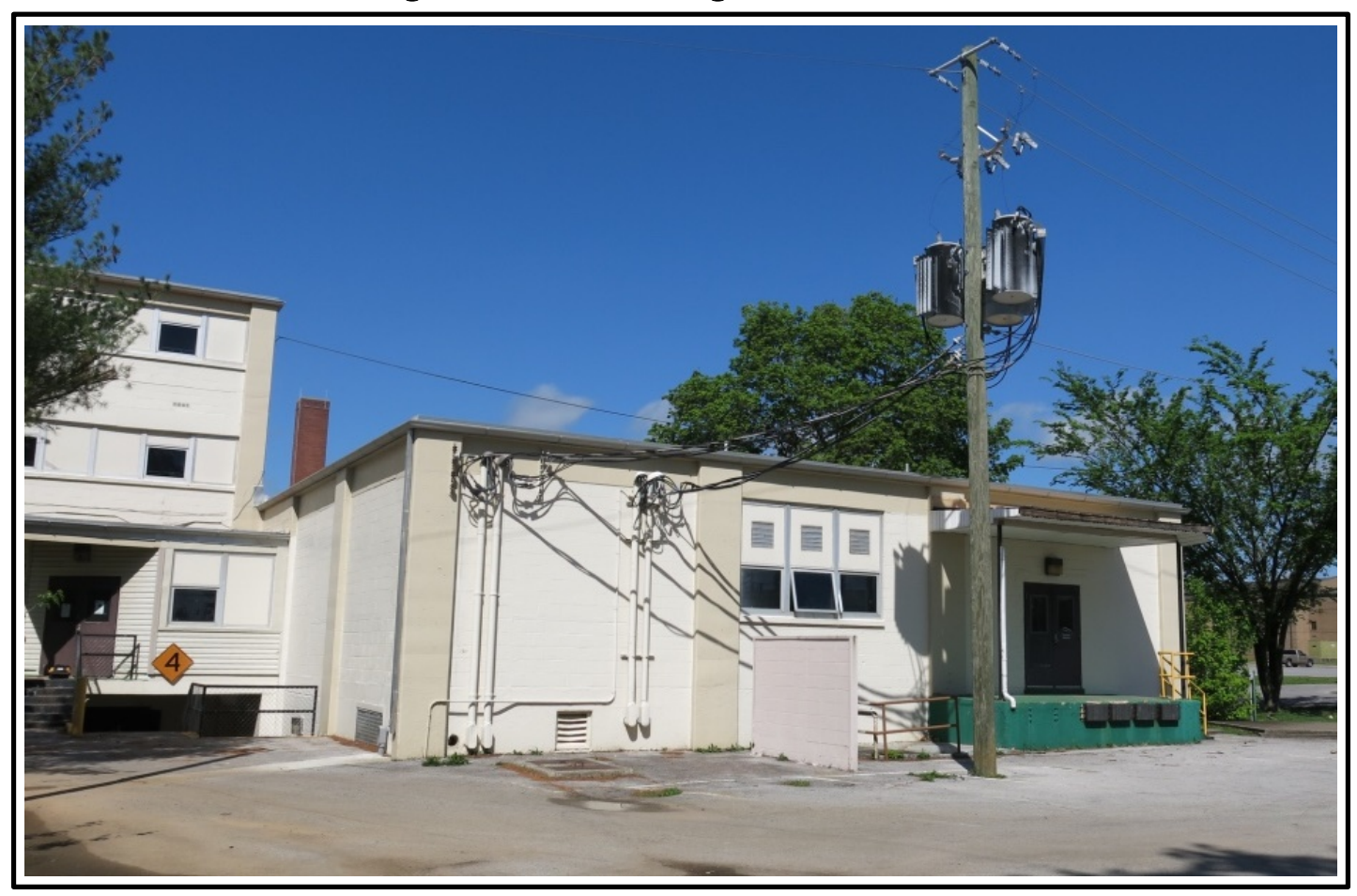

Figure 7. Classroom area inside Bldg. 6733.

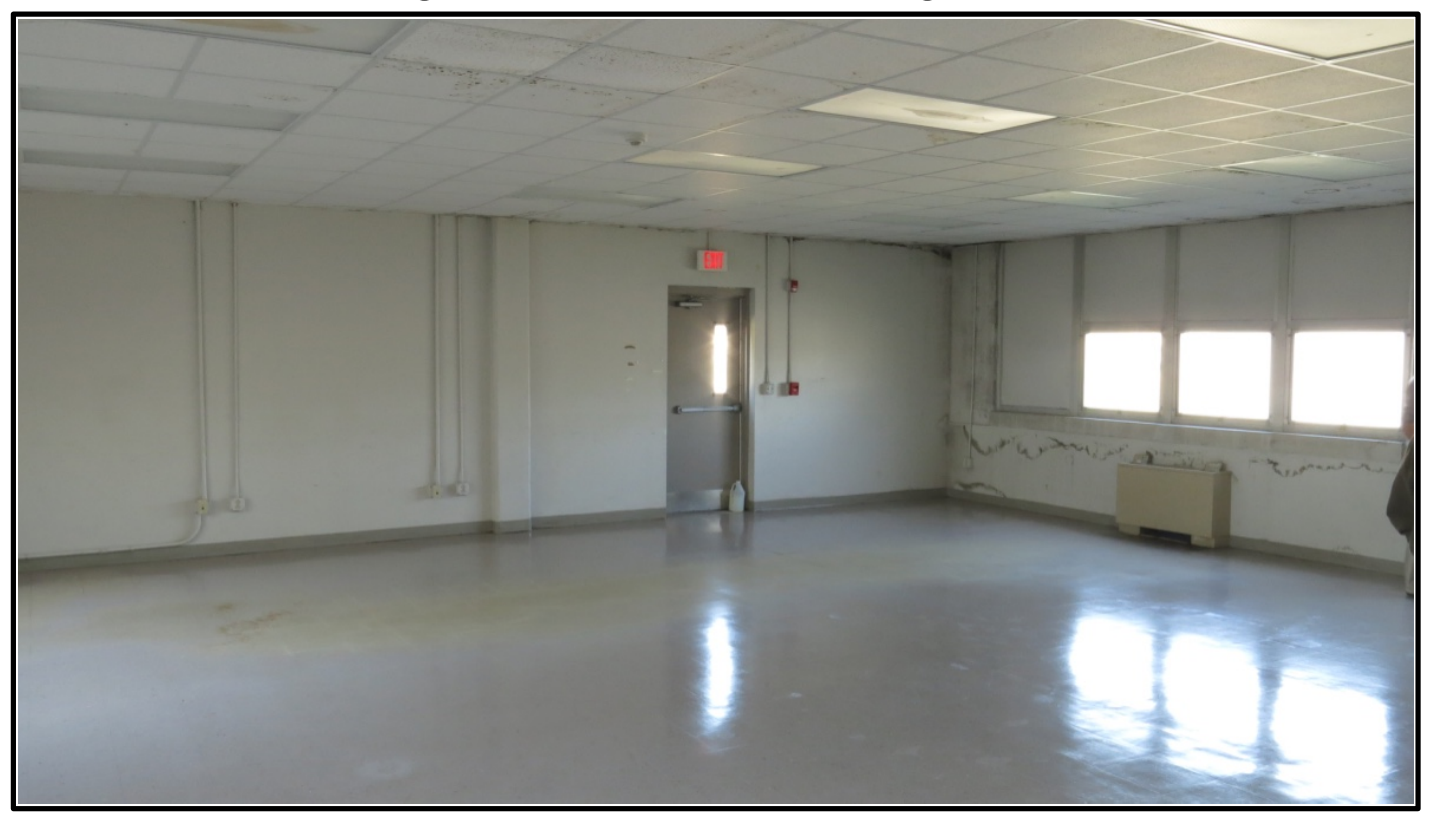


Figure 8. Bathroom area inside Bldg. 6733.

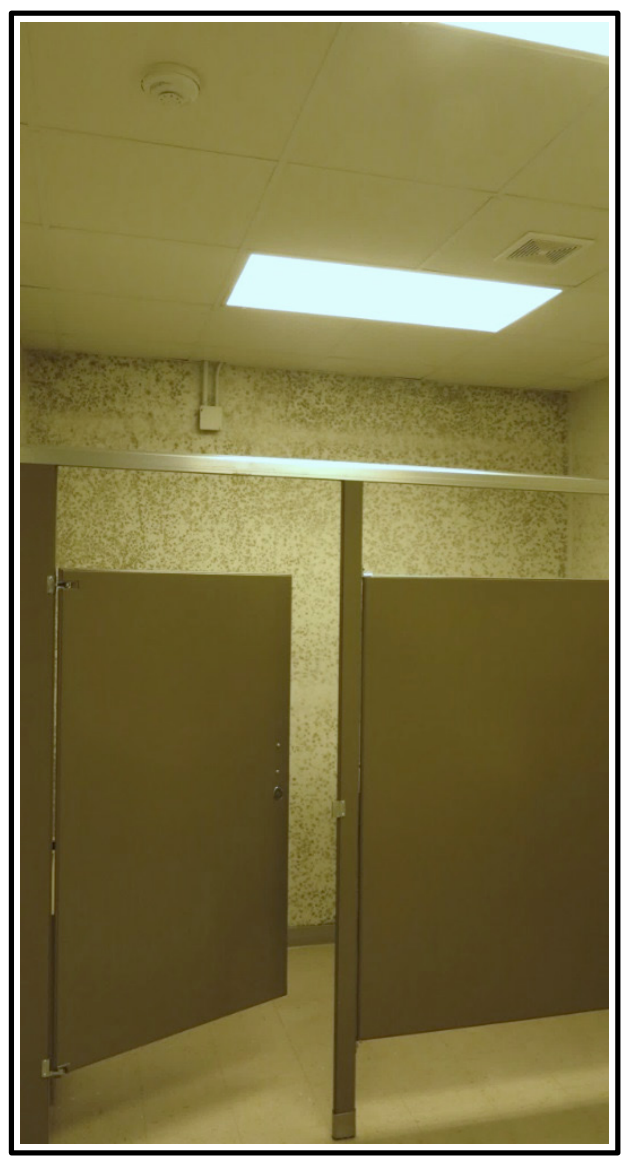

\subsection{Baseline/background sampling and analysis}

\subsubsection{General information}

Mold analyses are typically reported in terms of marker molds, outdoor molds, and hyphal fragments. This report focuses on marker molds, outdoor molds, and hyphal fragments described below (Kung'u 2016):

- Marker molds are uncommon mold types that are not typically found in significant numbers outside. These mold types, which are associated with more serious health problems, are often the best indicator of indoor mold issues. The following are typical marker molds:

○ Stachybotrys, known as "black mold," is considered the most dangerous mold type and is typically found in low numbers, if at all in outdoor samples. This mold has been linked with infant death.

- Chaetomium, a marker mold that is not commonly found at significant levels indoors and is associated with health problems including fibromyalgia, MS, Lyme disease, and others. 
- Common outdoor molds are typically molds that start growing outdoors, and that can still cause health issues when growing indoors. Health issues are usually related to cold, allergy, sinus, and respiratory problems. Typical outdoor molds are:

- Penicillium/Aspergillus, a genus that includes approximately 200 species and that is the most common fungal genus in the United States. Penicillium/Aspergillus is commonly found in house dust, water damaged wall paper and sheet rock, wallpaper glue, fabrics moist chipboards, in rotting food, in materials concealed behind.

- Cladosporium, a genus that includes approximately 28-40 species and that is one of the top three most common genuses in the United States found indoors on a variety of substrates.

- Basidiospores, which is an extremely common mold genus in outdoor samples that originate from fungus in gardens, forests, and woodlands. Basidiospores are often found in dirt of indoor potted plants or dust.

- Hyphal Fragments are produced during mold reproduction and are often an indicator of active growth. Hyphal fragments can be found in small amounts outdoors and indoors in healthy environments. Indoor levels under 200 are generally considered "normal."

Tables 3 to 6 list "typical" U.S. outdoor average mold levels for various parts of the United States (EMLab 2012, pp 22-23, 29) for the location and months closest to those applicable to this demonstration. Data were not available for Kentucky or Tennessee, and Illinois was determined the most representable data set based on the demonstration's geographic location and weather patterns.

Table 3. U.S. national outdoor average for April.

\begin{tabular}{|c|c|c|c|}
\hline Fungal Type & $\begin{array}{c}\text { Low } \\
\text { (Dry Climate) } \\
\text { (\#spores/m³) }\end{array}$ & $\begin{array}{c}\text { Medium } \\
\text { (\#spores/m³) }\end{array}$ & $\begin{array}{c}\text { High } \\
\text { (Humid Climate) } \\
\text { (\#spores } / \mathrm{m}^{3} \text { ) }\end{array}$ \\
\hline Alternaria & 13 & 27 & 53 \\
\hline Basidiospores & 67 & 240 & 960 \\
\hline Chaetomium & 13 & 13 & 27 \\
\hline Cladosporium & 107 & 320 & 1013 \\
\hline Penicillium/Aspergillus Types & 53 & 160 & 400 \\
\hline Stachybotrys & 13 & 13 & 40 \\
\hline
\end{tabular}


Table 4. U.S. national outdoor average for July.

\begin{tabular}{|c|c|c|c|}
\hline Fungal Type & $\begin{array}{c}\text { Low } \\
\text { (Dry Climate) } \\
\text { (\#spores/m³) }\end{array}$ & $\begin{array}{c}\text { Medium } \\
\left(\# \text { spores } / \mathrm{m}^{3} \text { ) }\right.\end{array}$ & $\begin{array}{c}\text { High } \\
\text { (Humid Climate) } \\
\text { (\#spores/m³) }\end{array}$ \\
\hline Alternaria & 13 & 40 & 107 \\
\hline Basidiospores & 107 & 427 & 3067 \\
\hline Chaetomium & 13 & 13 & 27 \\
\hline Cladosporium & 213 & 747 & 2120 \\
\hline Penicillium/Aspergillus Types & 80 & 213 & 613 \\
\hline Stachybotrys & 13 & 13 & 40 \\
\hline
\end{tabular}

Table 5. U.S. national outdoor average for October.

\begin{tabular}{|c|c|c|c|}
\hline Fungal Type & $\begin{array}{c}\text { Low } \\
\text { (Dry Climate) } \\
\text { (\#spores } / \mathrm{m}^{3} \text { ) }\end{array}$ & $\begin{array}{c}\text { Medium } \\
\left(\# \text { spores } / \mathrm{m}^{3}\right)\end{array}$ & $\begin{array}{c}\text { High } \\
\text { (Humid Climate) } \\
\left.\text { (\#spores/m } / \mathrm{m}^{3}\right)\end{array}$ \\
\hline Alternaria & 13 & 40 & 107 \\
\hline Basidiospores & 133 & 627 & 3625 \\
\hline Chaetomium & 13 & 13 & 27 \\
\hline Cladosporium & 213 & 800 & 2720 \\
\hline Penicillium/Aspergillus Types & 100 & 267 & 747 \\
\hline Stachybotrys & 13 & 13 & 40 \\
\hline
\end{tabular}

Table 6. Annual outdoor average for Illinois.

\begin{tabular}{|l|c|c|c|}
\hline Fungal Type & $\begin{array}{c}\text { Low } \\
\text { (Dry Climate) } \\
\left(\# s p o r e s / \mathbf{m}^{3}\right)\end{array}$ & $\begin{array}{c}\text { Medium } \\
\left.\text { (\#spores/m } \mathbf{m}^{3}\right)\end{array}$ & $\begin{array}{c}\text { High } \\
\text { (Humid Climate) } \\
\left(\# s p o r e s / \mathrm{m}^{3}\right)\end{array}$ \\
\hline Alternaria & 13 & 53 & 187 \\
\hline Basidiospores & 160 & 780 & 3220 \\
\hline Chaetomium & 7 & 13 & 27 \\
\hline Cladosporium & 120 & 693 & 2773 \\
\hline Penicillium/Aspergillus Types & 53 & 133 & 400 \\
\hline Stachybotrys & 13 & 13 & 53 \\
\hline
\end{tabular}

\subsubsection{Background sampling for this demonstration project}

Before application of the dry-fog technology in the demonstration buildings, background air samples and surface samples were taken inside and outside each building (Figure 9). Samples were taken at Bldg. 2261 on 20 March 2017 and at Bldg. 6733 on 21 March 2017. In Figure 9 below, the background/outdoor sample location at each building is shown as Locations \#5 and \#17, respectively.

Figure 10 shows the sample collection containers for both air and surface sampling. Air sampling was conducted using a Zefon International Mold 
Sampling Pump P/Z-Lite-IAQ (Figure 20). Sampling protocol for normal office space requires an air flow rate of 15 liters per minute (lpm) for a $5^{-}$ minute period (EMLab 2012, pp 22-23, 29). Zefon Air-O-Cell ${ }^{\mathrm{TM}}$ sample containers were used to capture the air samples. Surface samples were taken using the tape pull method (EMLab 2012, pp 37-38, 29).

Figure 9. Sampling locations at Bldgs. 2261 and 6733 (not to scale).

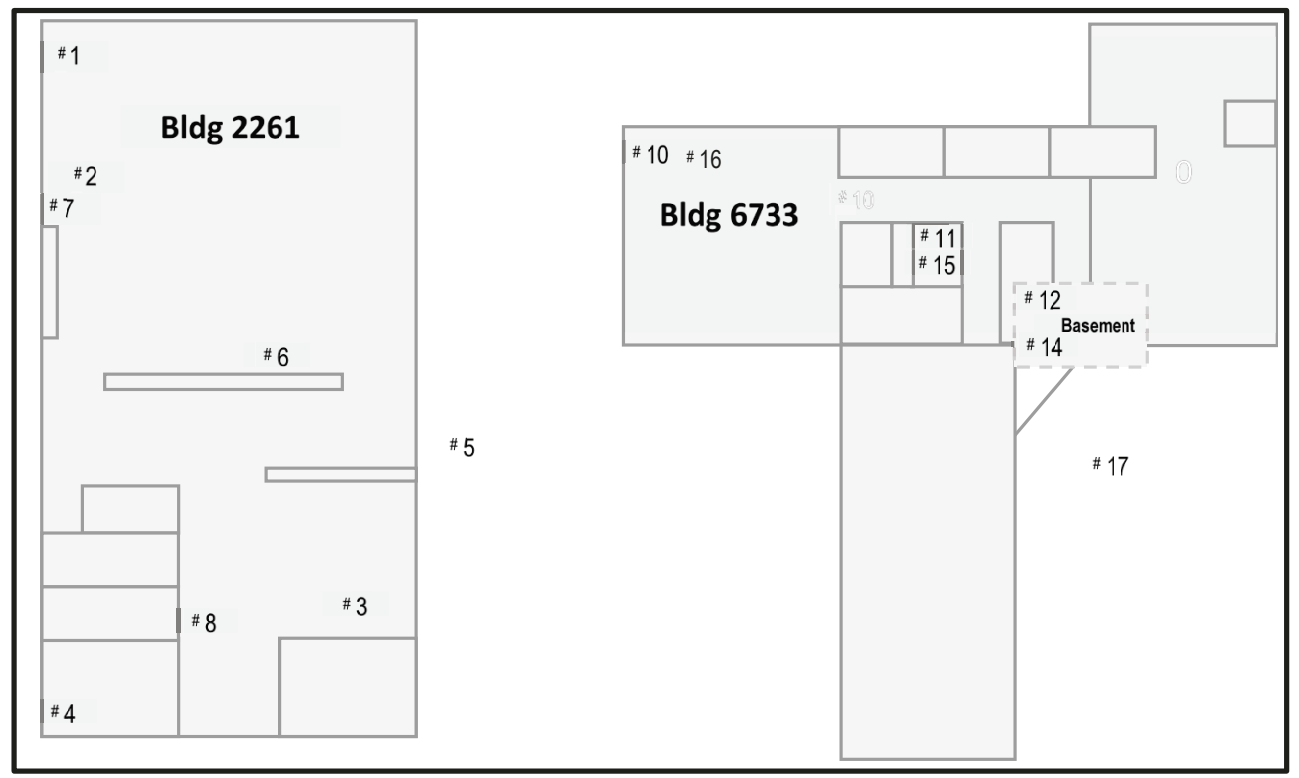

Figure 10. Air and surface sampling equipment.

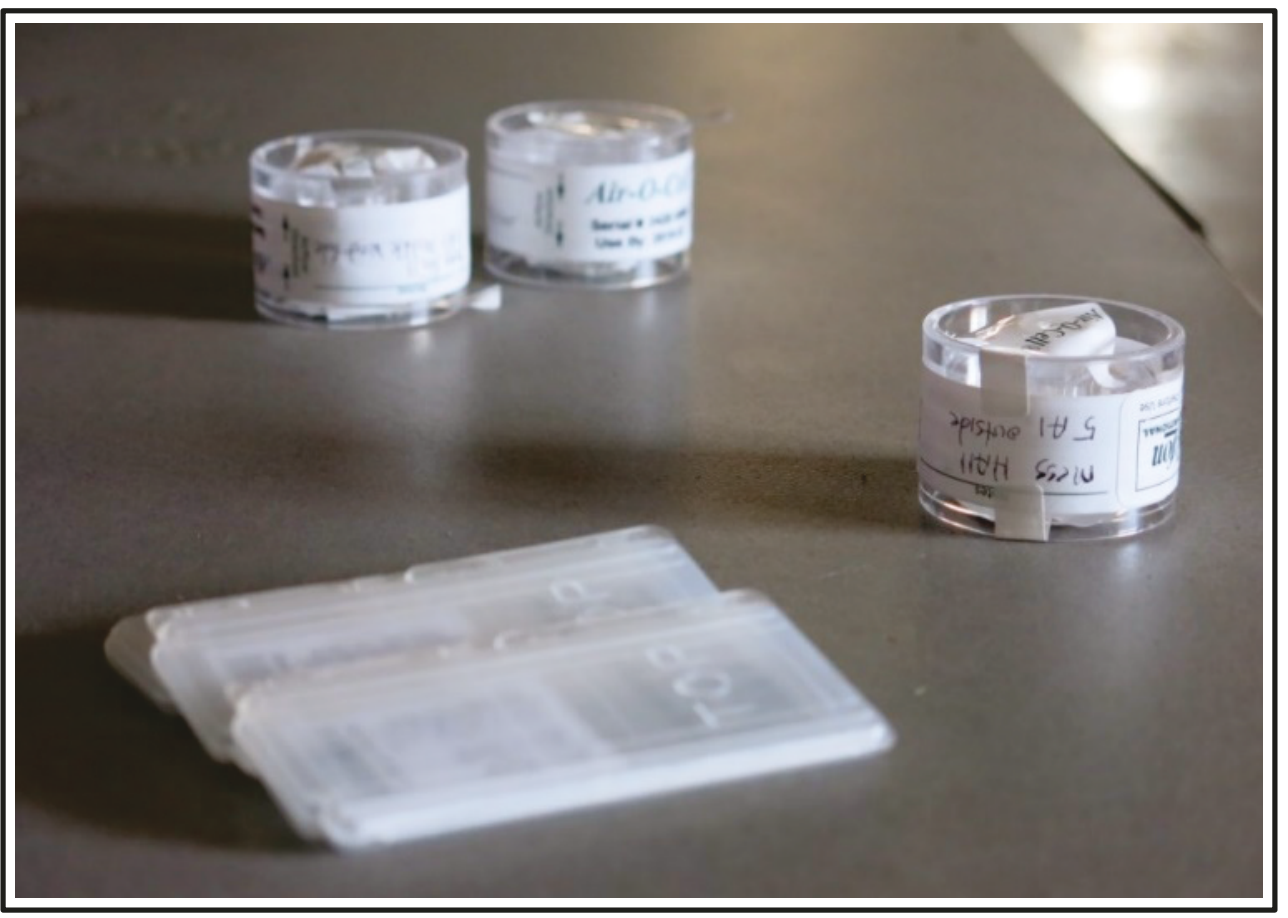




\subsubsection{Sample analysis}

Spore trap analysis and direct microscopic examination were performed for the samples collected at each location by EMLab P\&K (Lab Identification [ID] \#102297). Both of these methods are considered standard analyses when determining mold levels within the air and on surfaces of interest:

- Spore trap analysis is used to determine the number of a particular mold spore type within a known volume of air at a specific location. Results are reported in number of spores per cubic meter $\left(\# / \mathrm{m}^{3}\right)$. Positive results indicate airborne mold spores. Airborne mold spores contribute to an unhealthy environment and often lead to respiratory (and other) illnesses.

- Direct microscopic examination is used to determine specific types of mold spores present on the surface of any material at a particular location. Positive results indicate mold growth on the identified surface.

One of these two types of samples was performed on each sample collected during the demonstration. Chapter 3 of this report gives the results.

\subsection{Two-step dry-fog application}

The dry-fog is a gas/vapor with micron sized particles that can cover, penetrate, and envelope mold spores. The small size (6-8 microns) of the particles ${ }^{*}$ makes it possible to treat materials and spaces that current mold removal technologies cannot access. The first step of the two-step dry-fog process is the application of InstaPURE, which is a powerful disinfectant that destroys mold spores and disinfects any surface it touches. The second step of the two-step process is the application of EverPURE, which is an antimicrobial barrier that destroys bacteria or viruses that come in contact with surfaces treated with EverPURE. The U.S. Environmental Protection Agency (USEPA) has approved both InstaPURE and EverPURE for use in all 50 U.S. states.

The dry-fog treatment system is completely mobile. It includes compressed air, spray nozzles, and the dry-fog box (Figure 11). 
Figure 11. Equipment to apply the dry-fog treatment.

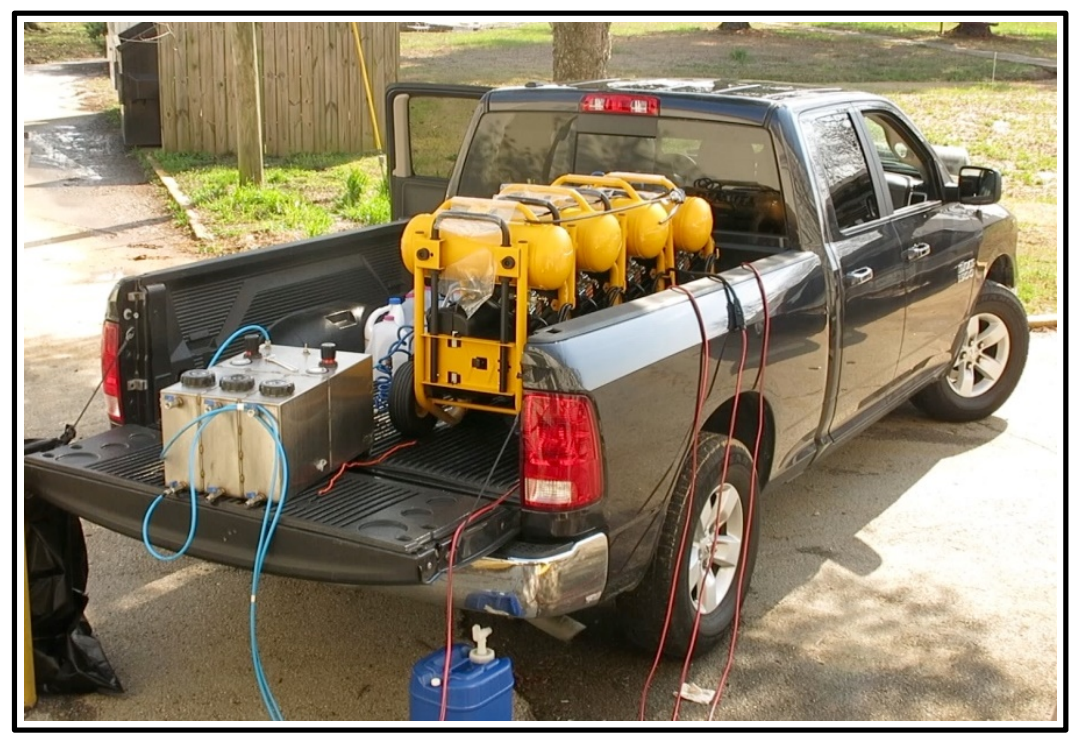

The dry-fog technology is housed inside the metal box (Figure 12). Independent control of the flow rates and pressures for the liquid and air provides the patented ability to generate the dry-fog. The dry fog is made up of particles ranging from 6-8 microns in diameter. Mold spores generally vary from 10-30 microns in diameter (Peacock Enterprises 2017). The dry fog's small particle size (much smaller than the mold spores) provides a mechanism to treat areas inaccessible to liquid treatments, and ensures that the fog can physically infiltrate all spaces and porous materials available to mold spores.

Figure 12. Dry-fog technology apparatus.

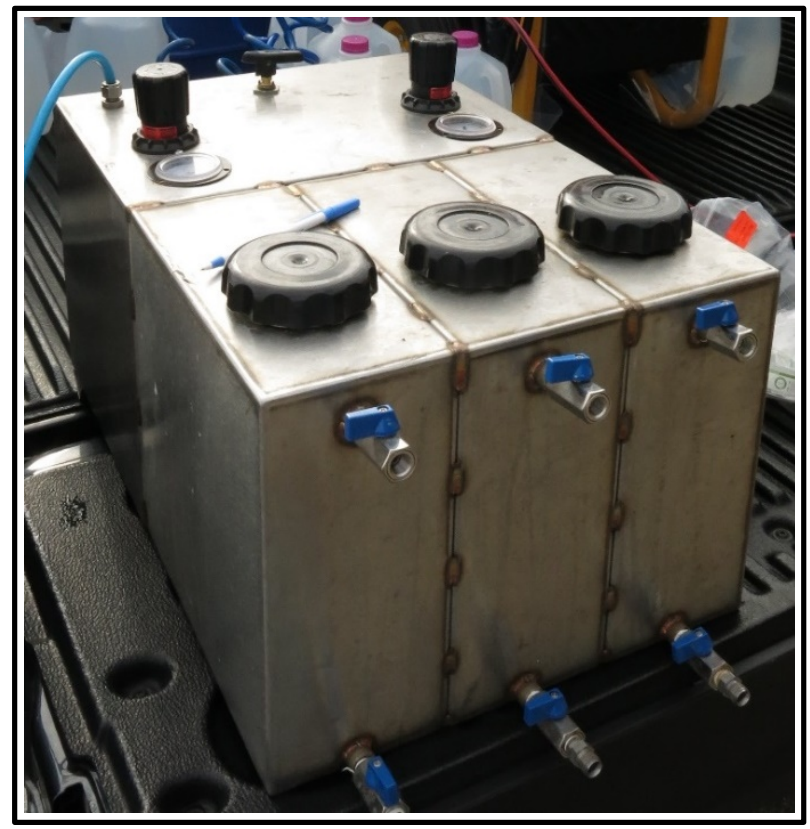


Air compressors provide pressure to quickly distribute the dry fog. The dry fog disseminates rather readily covering $1000 \mathrm{sq} f \mathrm{ft}$ having 8 - to $10-\mathrm{ft}$ ceiling heights in approximately 1 hour (i.e., 10,000 cu ft per hour [cu ft/hr]). This is accomplished with minimal manpower requirements. A single individual can completely treat, including mobilizing and demobilization, a $2000 \mathrm{sq} f \mathrm{ft}$ single-story facility/space in approximately 3 hours. Larger treatment volumes take correspondingly longer treatment times for a given number of air compressors and spray nozzles.

Bldg. 2261 took approximately 5 hours to treat. This included mobilization, surface and air sampling, and demobilization. Bldg. 6733 took a total of approximately 4 hours to treat and accomplish the same tasks.

The dry-fog technology is relatively inexpensive when compared to current mold removal procedures and their labor intensive requirements. Costs for the treatment of a one story building are estimated at approximately $\$ 0.90-\$ 1.20 / \mathrm{sq} \mathrm{ft}$. This estimate does not include travel costs by the vendor. Actual costs will be higher or lower depending on travel time, on multi- versus single-story buildings, and on special circumstances such as the geographical location, building use(s), and building layout.

Appendix A includes Material Specifications and Data Sheets (MSDSs) for InstaPURE and EverPURE. Given the chemical make-up of these liquids and the application process, i.e., the addition of deionized water and atmospheric air, there are no (and to date have not been) adverse effects to humans or the contents within the treated buildings. The vendor (and others) have treated thousands of residential, commercial, and industrial buildings with these products with no negative effects on inhabitants or materials within treated buildings.

The dry-fog technology is currently available via licensing from the vendor. The vendor provides startup equipment, training (in person and online), and access to chemicals, local/national marketing materials, and business development support.

The treatment is performed by introducing the dry-fog via spray nozzles (Figures 13-15). 
Figure 13. Dry-fog being applied via spray nozzle in Bldg. 2261.

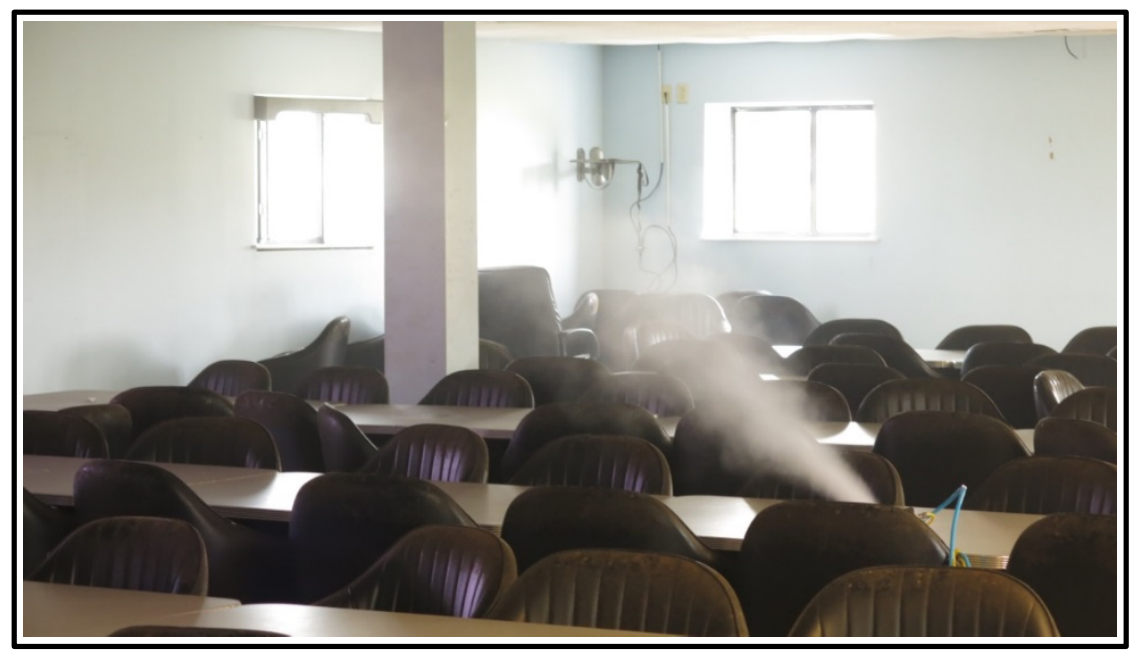

Figure 14. Dry-fog being applied to intake of HVAC ducting Bldg. 2261.

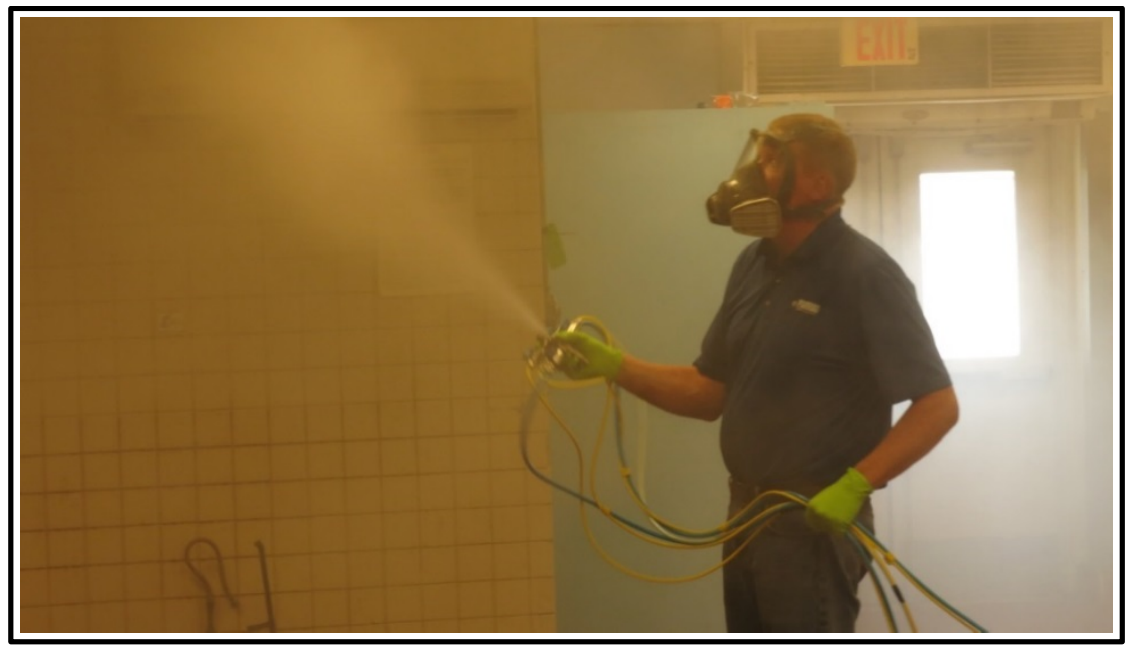

Figure 15. Dry-fog being applied via spray nozzles in Bldg. 6733.

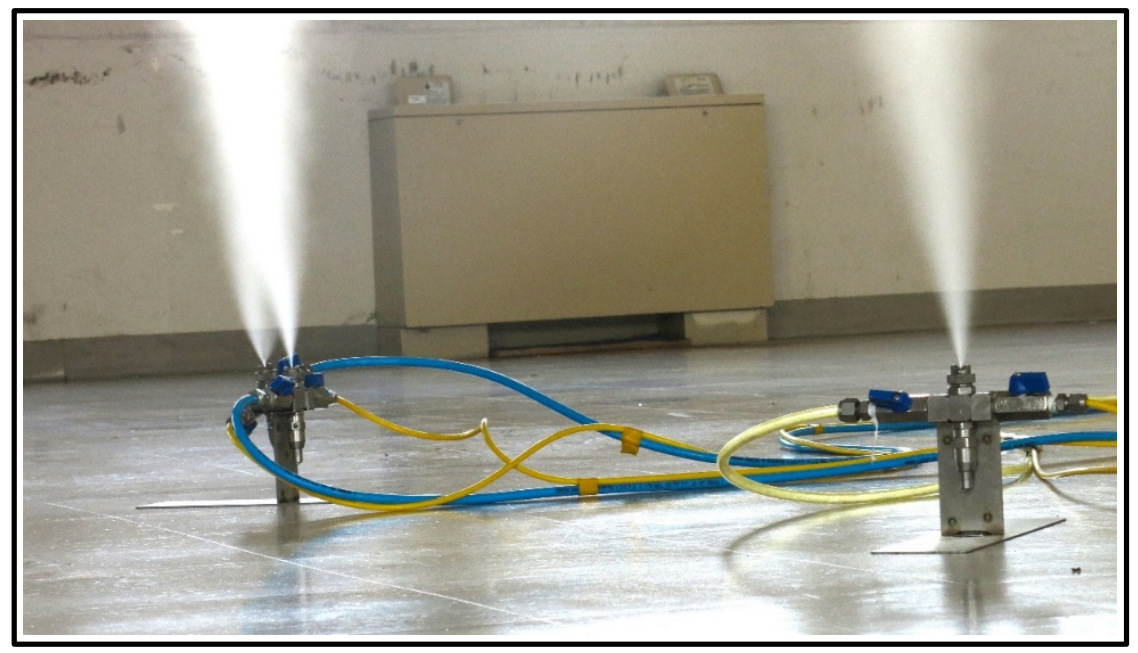


Figure 16 shows an example of minimalistic plastic barriers put in place to generate enough back pressure to provide positive pressure and to ensure coverage when doing smaller areas within larger, more spacious rooms. Although these barriers do not completely contain the dry-fog, they do allow the dry fog to accumulate sufficiently to provide treatment (Figure 17).

Figure 16. Positive pressure at various points within Bldg. 2261.

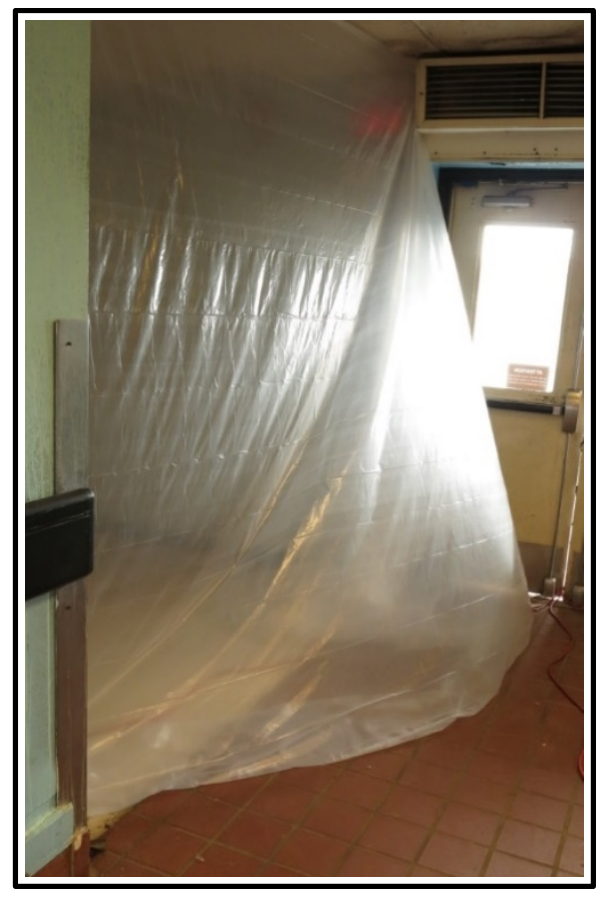

Figure 17. Dry-fog accumulation in kitchen area within Bldg. 2261.

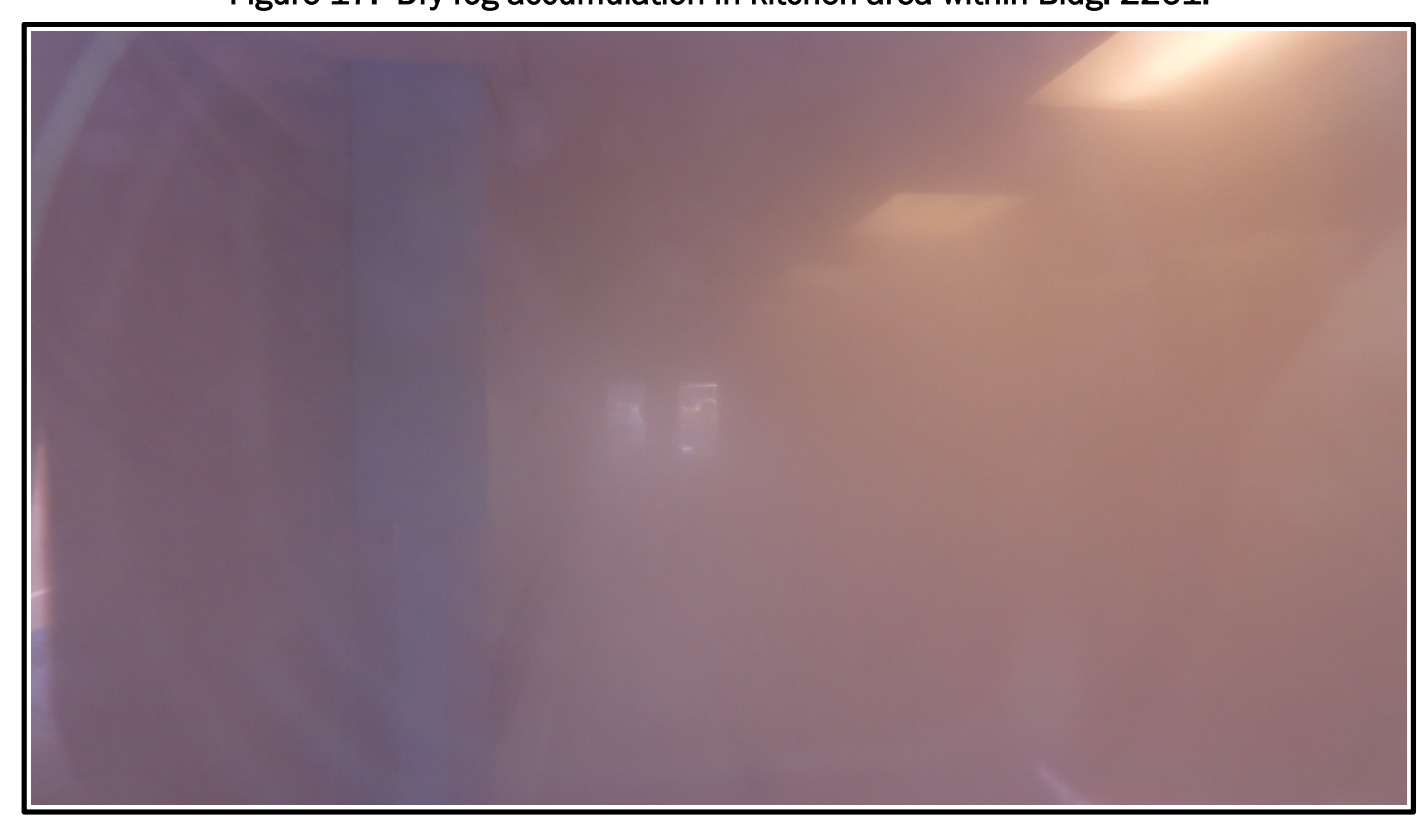


Indicator strips are placed at various locations within the treatment area to ensure coverage. The strips are initially white and turn black (Figure 18) as the dry-fog fills the air at a concentration sufficient to indicate full treatment. HVAC systems are operated long enough to ensure complete coverage (i.e., multiple duct system volumes) throughout the duct work and associated filters/vents.

Figure 18. Indicator strips signify treatment (i.e., white to black).

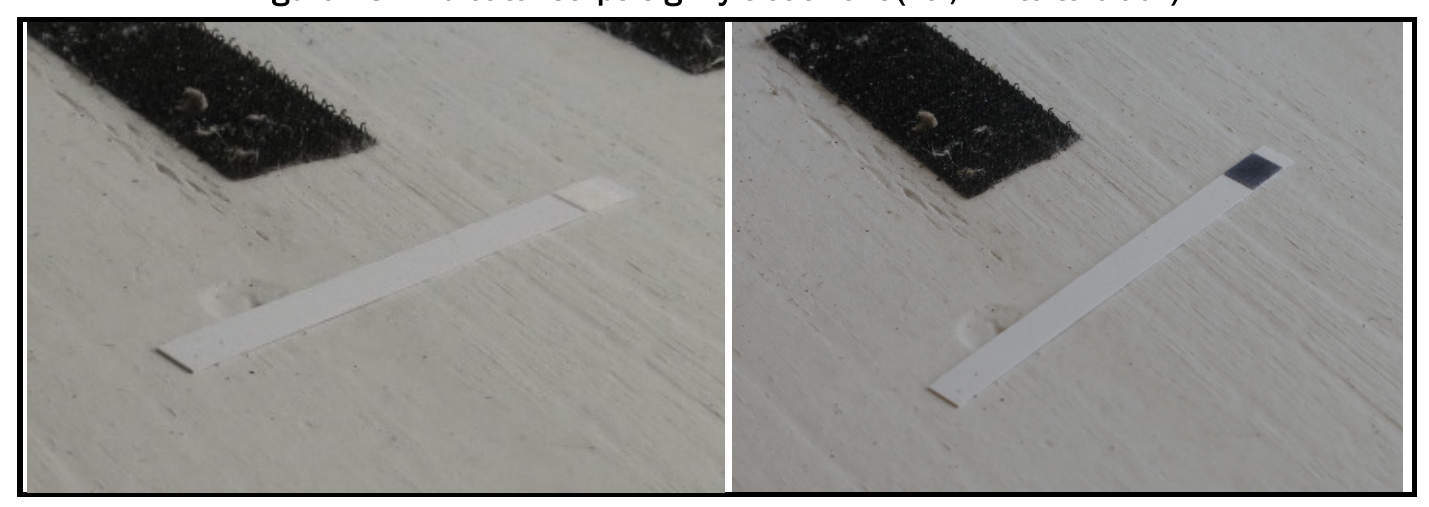

Note that the treatment does not remove the black appearance of mold (Figure 19). Even though the treatment has eliminated the mold spores, treated surfaces will still appear "moldy" so it is essential that air and surface sampling be performed (before and after treatment) to provide quantitative measurements of the treatment's removal effectiveness. An additional advantage of the dry-fog treatment is that surfaces can be cleaned with typical household cleaning products rather than with the more hazardous chemicals used for traditional mold treatment and cleaning.

Figure 19. Mold growing near duct vents in BIdg. 2261.

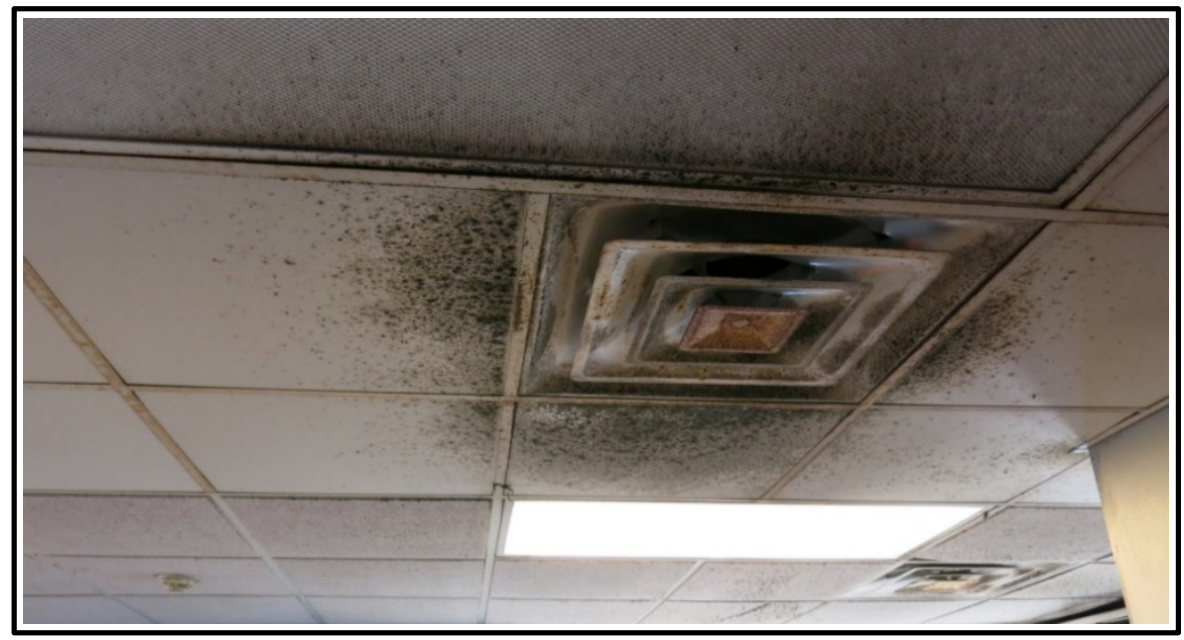




\subsection{Verification sampling and analysis}

After the dry-fogging application, Pure Maintenance, LLC (with members of the project team present) conducted air and surface sampling (Figure 20). Continued sampling occurred at 1 month (25 April 2017), 3 months (22 June 2017), and 6 months (12 September 2017) following treatment. Chapter 3 of this report includes results and analyses of these sampling events. Appendix B includes all raw laboratory analysis results.

Figure 20. Air and surface sampling.

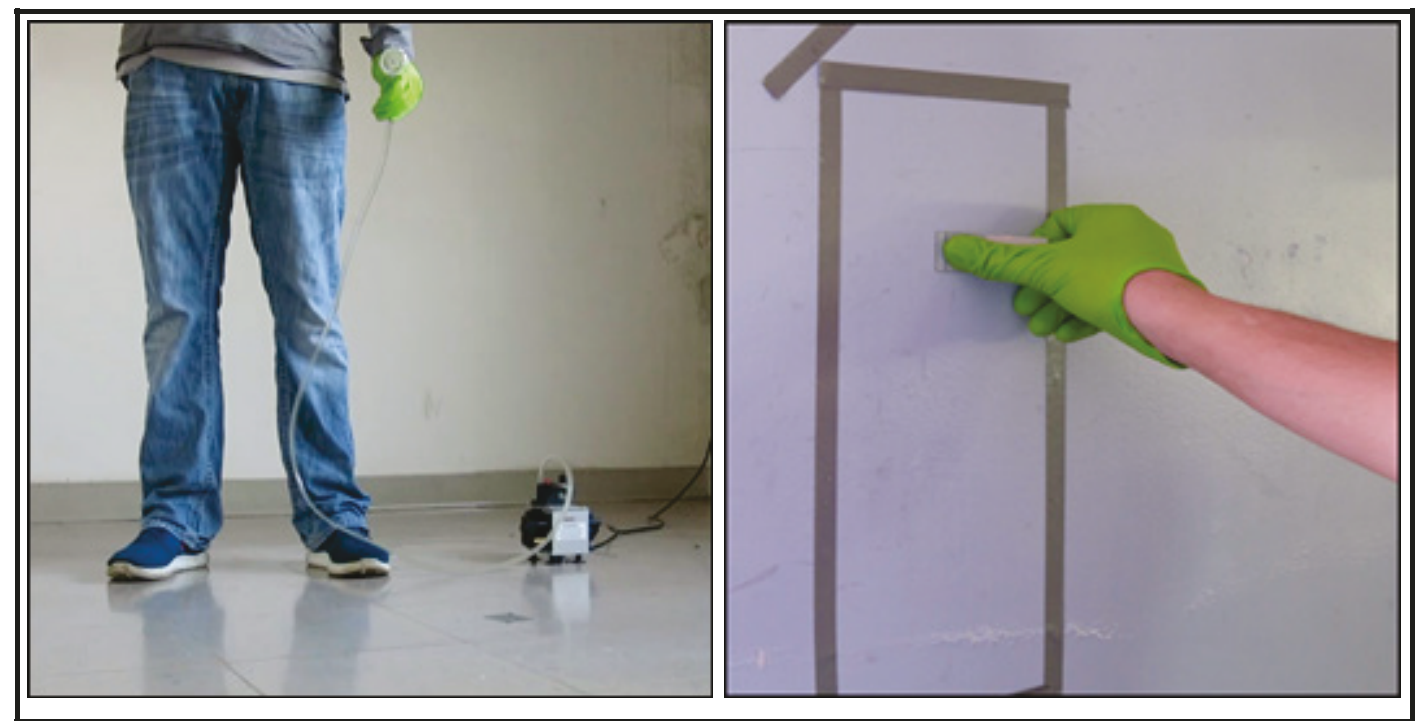




\section{Results}

\subsection{Summary results}

The dry-fog treatment was successful in reducing and maintaining mold at below background levels over the 6-month demonstration period. Figures 21 to 23 show and Table 7 lists the results of air sampling and surface sampling at Bldg. 2261. Figures 24 to 26 show and Table 8 lists the results of air sampling and surface sampling at Bldg. 6733. Sections 3.1 and 3.2 give detailed results specific to individual surface and air sampling locations within each building.

Figure 22 shows that the total spore count weighted across all air sampling locations associated with Bldg. 2261 decreased from 64,126 spores $/ \mathrm{m}^{3}$ before treatment, to 3,067 spores $/ \mathrm{m}^{3}$ at 6 months after treatment. Over this same time period, the outdoor/background total spore count increased from 590 spores $/ \mathrm{m}^{3}$ before treatment, up to 19,000 spores $/ \mathrm{m}^{3}$ at 6 months after treatment. Simply put, while the outdoor/background total spore count increased 3,120\%, the indoor (i.e., treated space) total spore count decreased $95.21 \%$.

Figure 25 shows that the total spore count weighted across all air sampling locations associate with Bldg. 6733 decreased from $556,057 \mathrm{spores} / \mathrm{m}^{3}$ before treatment, to 3,044 spores $/ \mathrm{m}^{3}$ at 6 months after treatment. Over this same time period, the outdoor/background total spore count increased from 3,100 spores $/ \mathrm{m}^{3}$ to 20,000 spores $/ \mathrm{m}^{3}$ at 6 months after treatment. As the outdoor total spore count increased $545.2 \%$, the indoor (i.e., treated space) total spore count decreased by $99.45 \%$ 
Figure 21. Bldg. 2261 Stachybotrys/Chaetomium vs. Stachybotrys/Chaetomium (background).

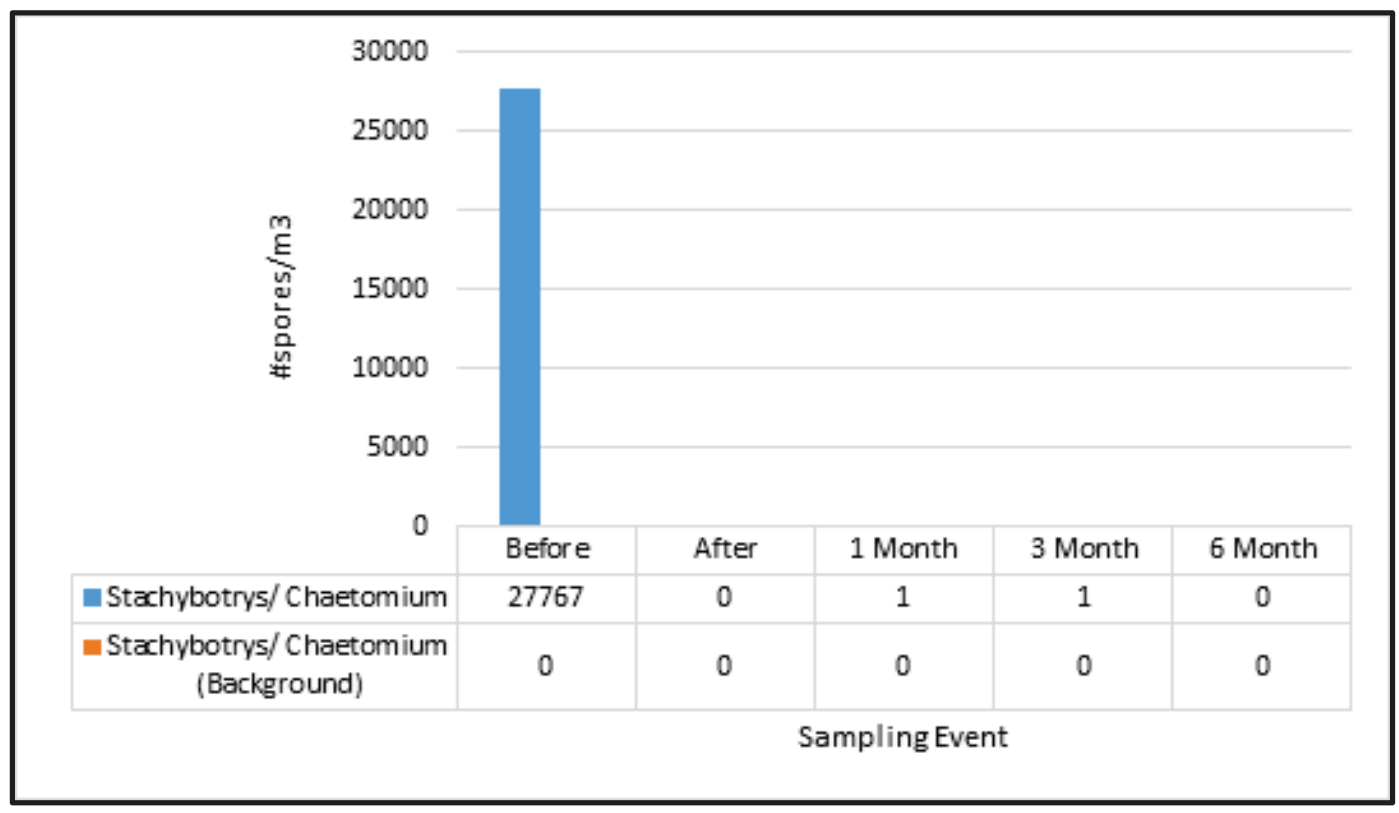

Figure 22. Bldg. 2261-Total Spores vs. Total Spores (background).

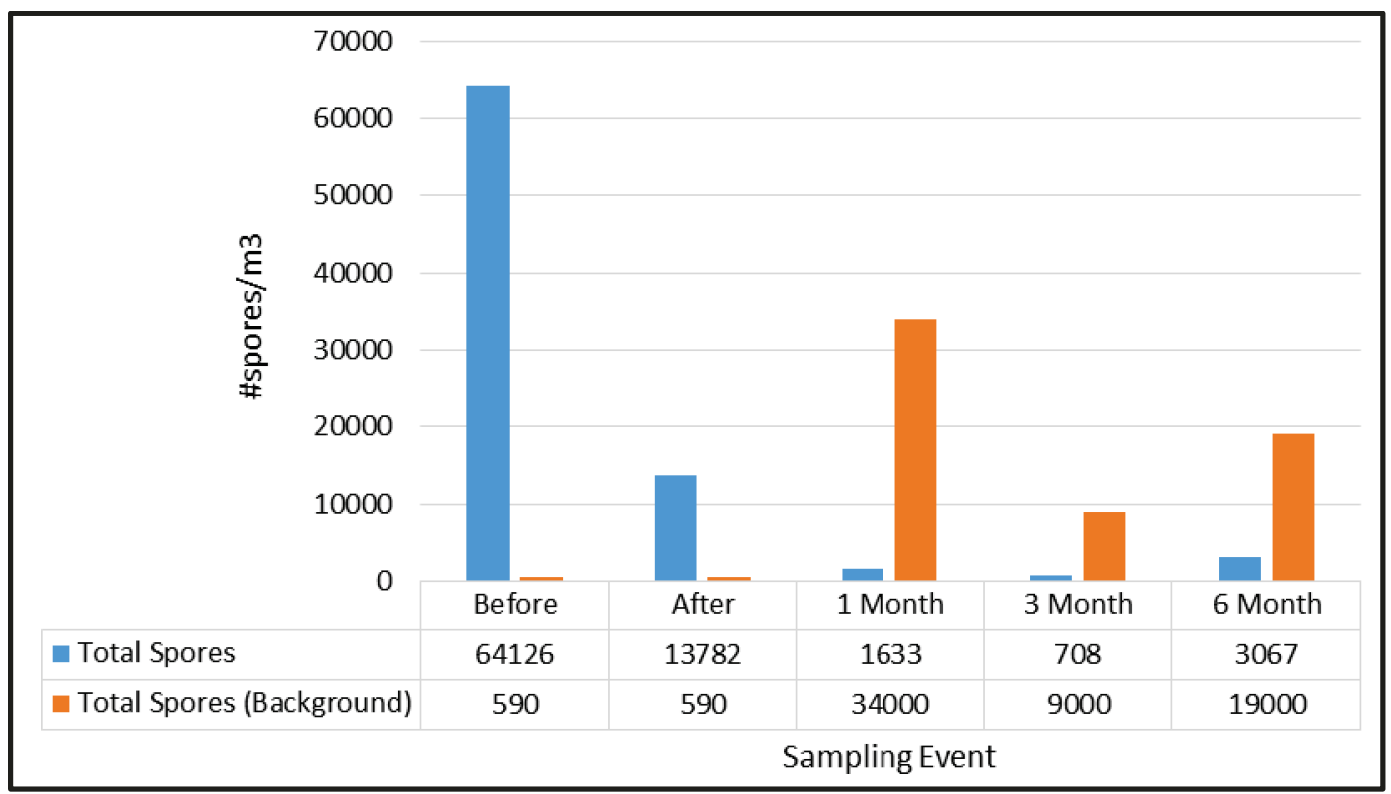


Figure 23. Bldg. 2261-Hyphal Fragments vs. Hyphal Fragments (background).

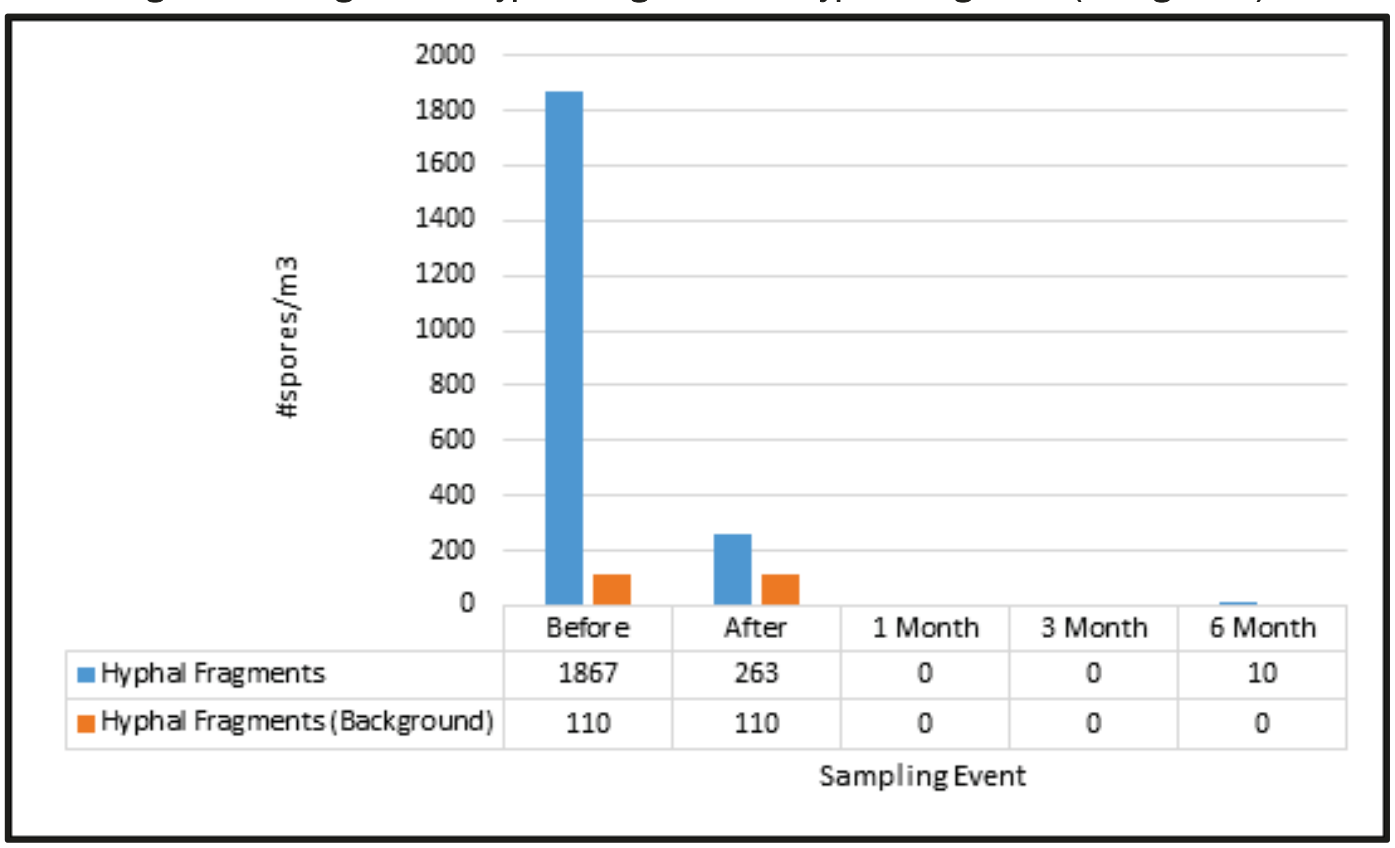

Table 7. Surface sampling results in Bldg. 2261.

\begin{tabular}{|l|c|c|c|c|c|}
\hline Fungal Type & Before & After & 1 Month & 3 Month & 6 Month \\
\hline Cladosporium & $6+$ & $<1$ & 0 & 0 & 0 \\
\hline Penicillium/Aspergillus & 0 & 0 & 0 & 0 & 0 \\
\hline Total & very few & very few & very few & 0 & 0 \\
\hline
\end{tabular}

Figure 24. Bldg. 6733-Stachybotrys/Chaetomium vs. Stachybotrys/Chaetocmium (background).

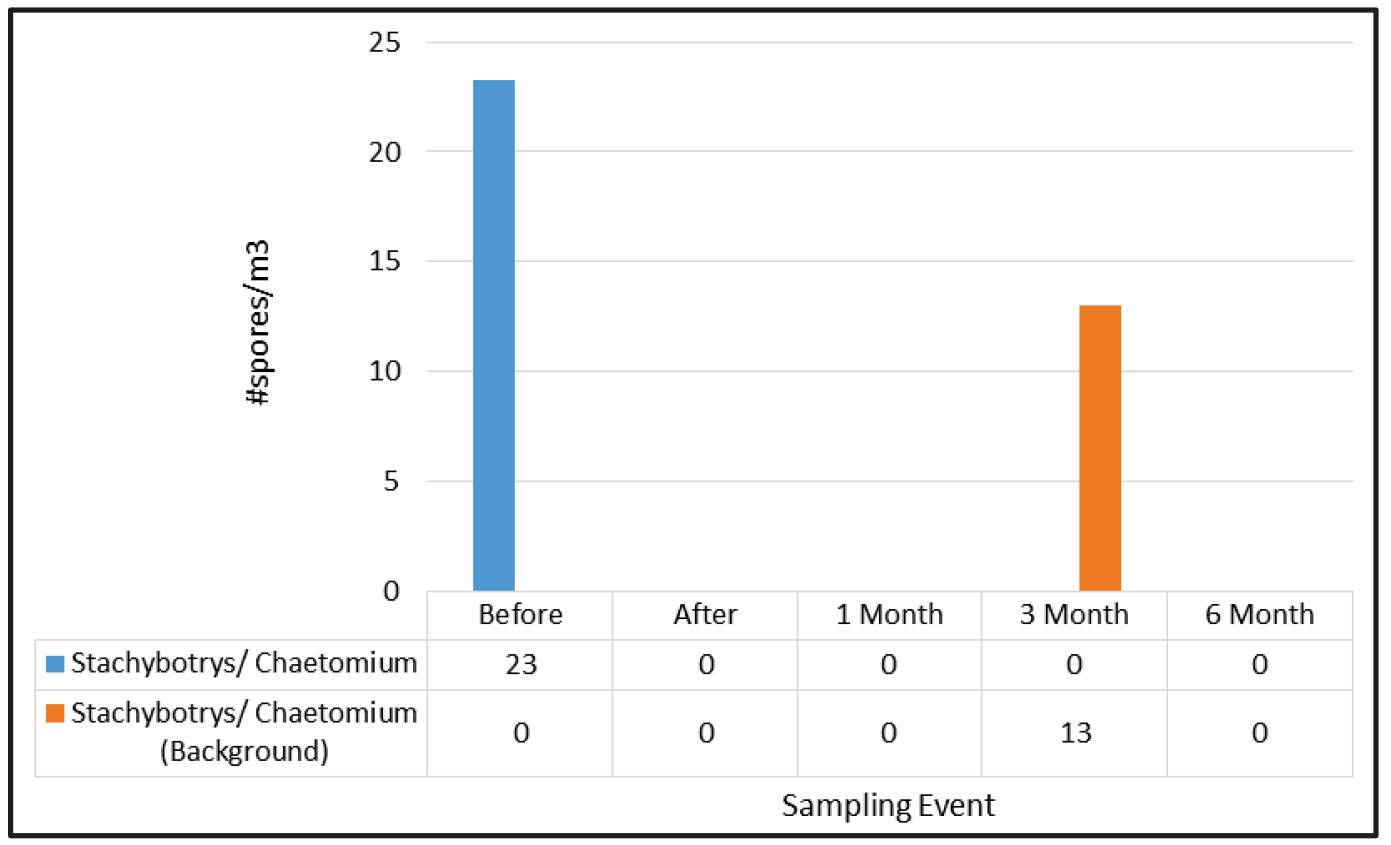


Figure 25. Bldg. 6733-Total Spores vs. Total Spores (background).

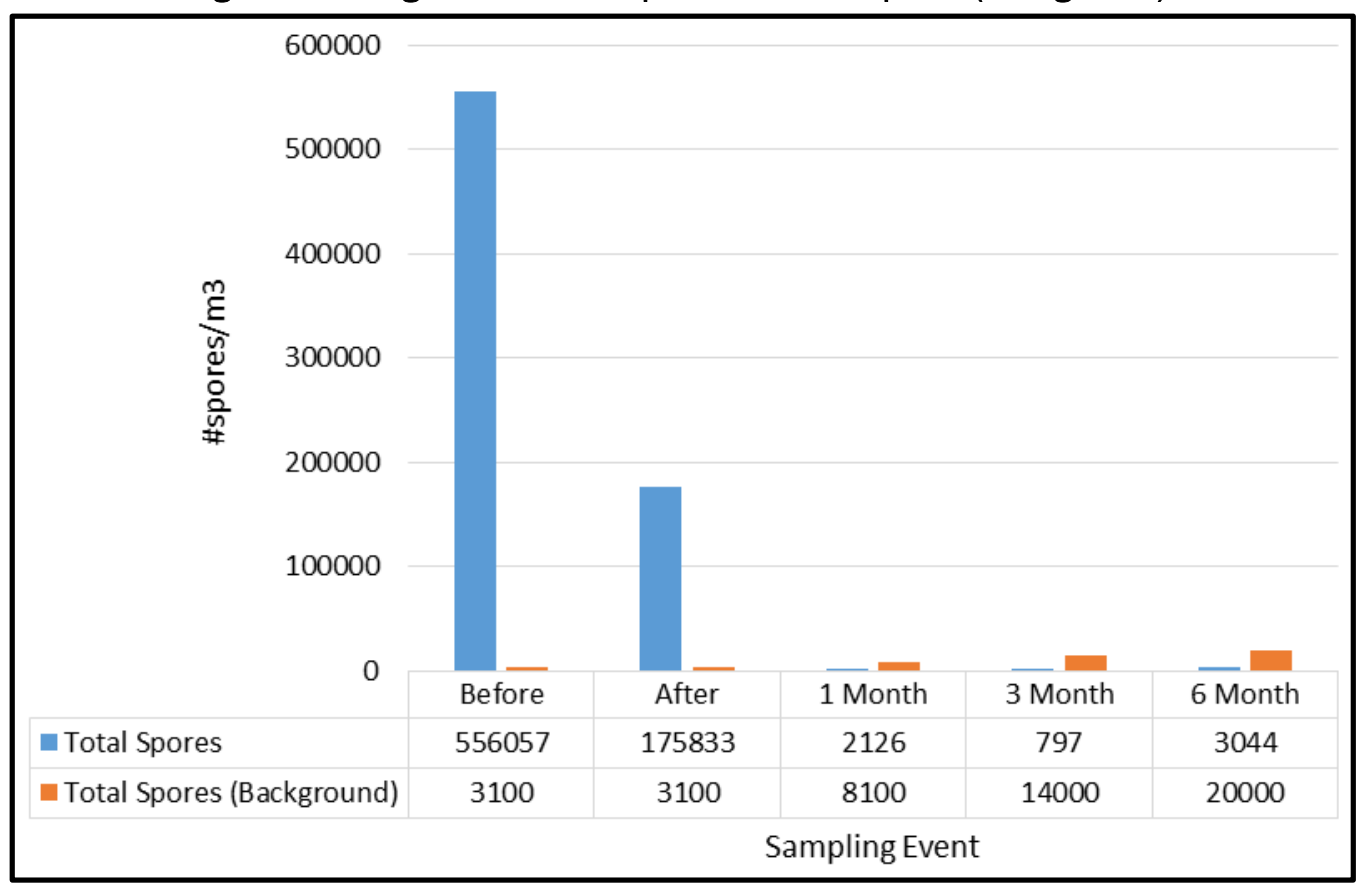

Figure 26. Bldg. 6733-Hyphal Fragments vs. Hyphal Fragments (background).

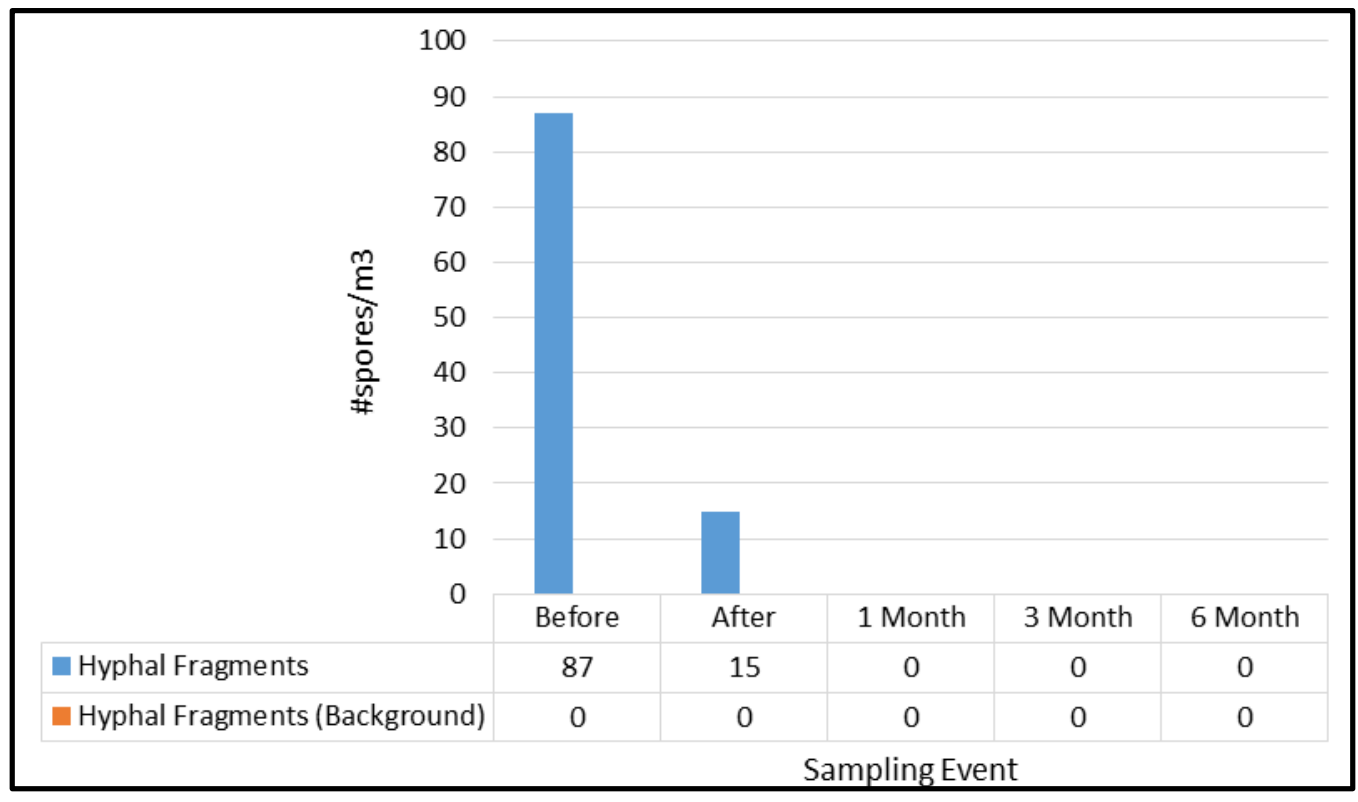

Table 8. Surface sampling results in Bldg. 6733.

\begin{tabular}{|l|c|c|c|c|c|}
\hline Fungal Type & Before & After & 1 Month & 3 Month & 6 Month \\
\hline Cladosporium & $10+$ & $<1+$ & 0 & 0 & 0 \\
\hline Penicillium/Aspergillus & 0 & $2+$ & 0 & 0 & 0 \\
\hline Total & very few & very few & very few & 0 & very few \\
\hline
\end{tabular}




\subsection{Dining facility - Bldg. 2261}

\subsubsection{Air sampling}

Table 9 lists the results of the air sampling at Bldg. 2261. Each sampling location was allocated a representative number of square feet within the total square footage treated. A summation of the \#spores $/ \mathrm{m}^{3}$ at each sampling location within the building, multiplied by the associated square feet for each sample, divided by the total number of square feet treated, provides a weighted average of the sampling results, which comprises a single value for each fungal type for each building. The efficacy of the treatment is determined by comparing these values to the background levels at the time of each sampling. Values at or below background levels indicate that the treatment and/or removal was (and continues to be) effective.

Table 9. Air sampling results (\#spores/m³) for Bldg. 2261.

\begin{tabular}{|c|c|c|c|c|c|c|c|}
\hline ID & $\begin{array}{l}\text { Associated } \\
\text { Area (sq ft) }\end{array}$ & Fungal Type & Before & After & 1 Month & 3 Month & 6 Month \\
\hline \multirow[t]{3}{*}{ \#1 } & \multirow[t]{3}{*}{2268} & $\begin{array}{l}\text { Stachybotrys/ } \\
\text { Chaetomium }\end{array}$ & 0 & 0 & 0 & 0 & 0 \\
\hline & & Total & 19000 & 15000 & 1500 & 170 & 2800 \\
\hline & & Hyphal Fragments & 1300 & 430 & 0 & 0 & 0 \\
\hline \multirow[t]{3}{*}{ \#2 } & \multirow[t]{3}{*}{756} & $\begin{array}{l}\text { Stachybotrys/ } \\
\text { Chaetomium }\end{array}$ & 0 & 0 & 0 & 0 & 0 \\
\hline & & Total & 48000 & 12000 & 1400 & 480 & 4300 \\
\hline & & Hyphal Fragments & 2000 & 0 & 0 & 0 & 0 \\
\hline \multirow[t]{3}{*}{ \#3 } & \multirow[t]{3}{*}{486} & $\begin{array}{l}\text { Stachybotrys/ } \\
\text { Chaetomium }\end{array}$ & 0 & 0 & 0 & 0 & 0 \\
\hline & & Total & 110000 & 12000 & 2000 & 2800 & 2500 \\
\hline & & Hyphal Fragments & 2700 & 0 & 0 & 0 & 53 \\
\hline \multirow[t]{3}{*}{$\# 4$} & \multirow[t]{3}{*}{198} & $\begin{array}{l}\text { Stachybotrys/ } \\
\text { Chaetomium }\end{array}$ & 520000 & 0 & 13 & 13 & 0 \\
\hline & & Total & 530000 & 11000 & 2000 & 2600 & 2800 \\
\hline & & Hyphal Fragments & 5800 & 0 & 0 & 0 & 53 \\
\hline \multirow[t]{3}{*}{ \#5 } & \multirow[t]{3}{*}{$\begin{array}{l}\text { Outdoor/ } \\
\text { Background }\end{array}$} & $\begin{array}{l}\text { Stachybotrys/ } \\
\text { Chaetomium }\end{array}$ & 0 & 0 & 0 & 0 & 0 \\
\hline & & Total & 590 & 590 & 3400 & 9000 & 19000 \\
\hline & & Hyphal Fragments & 110 & 110 & 0 & 0 & 0 \\
\hline
\end{tabular}


Samples \# 3 and \#4 show an increase in hyphal fragments at the 6-month sampling event (highlighted in yellow). Even though the levels increased (from zero for the previous sampling events), they are still well below the levels before treatment. However, levels are above the background level of zero. Ideally, a future sampling round could potentially determine if this is an increasing trend, or an increase due to activity within the room where Sample \# 4 was taken, and adjacent to the area represented by Sample \#3.

While performing the 3-month sampling event, team members encountered demolition activities in the room represented by Sample \#4. Figure 27 shows the debris and the meter reading showing $100 \%$ moisture content on the wall surface. The wall was damp to the touch and clearly saturated with water. The adjacent room, represented by Sample \#3, had recently began to leak from the ceiling (Figure 28). It is believed that these changes to the interior environmental/structural conditions played a role in the increased total spore count. However, it should be noted that the background total spore count continued to increase beginning with the 1month sampling event through the 6-month sampling event, where background was between four and seven times greater than the indoor sample results.

Figure 27. Wall surface moisture content of $100 \%$ near Sample Location \#4.

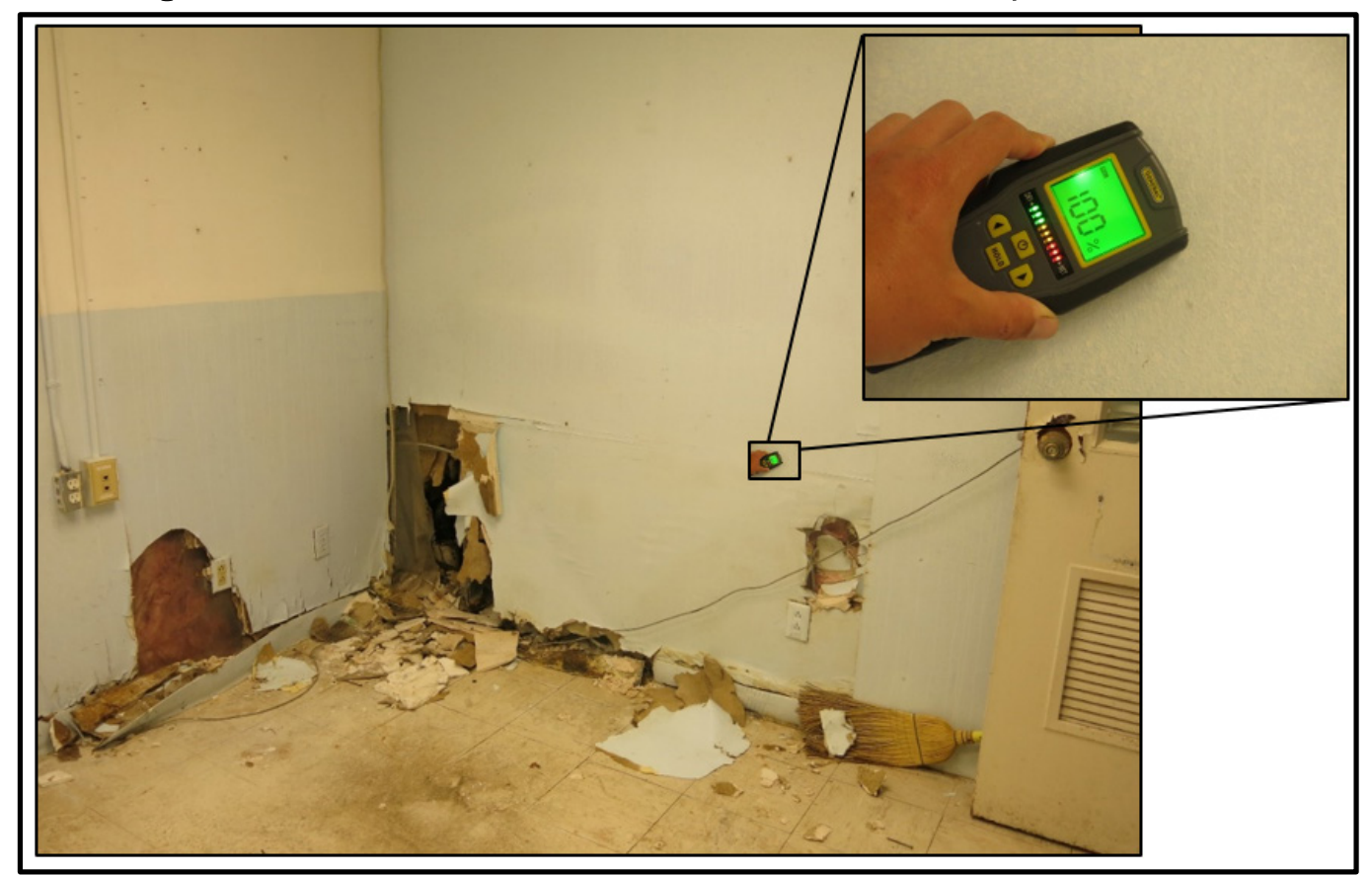


Figure 28. Leakage from ceiling piping or roofing.

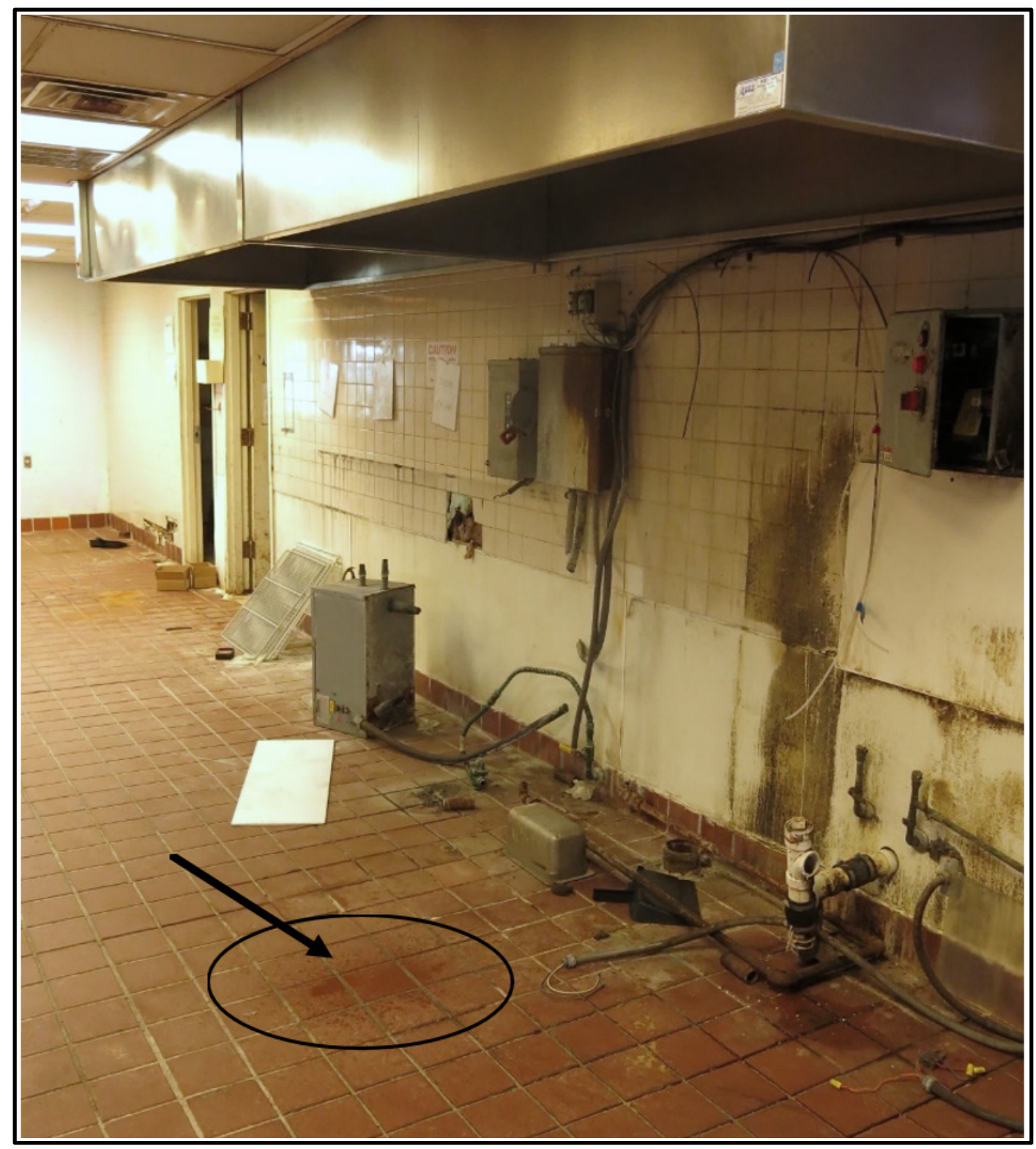

\subsubsection{Surface sampling}

Table 10 lists the results of the surface sampling at Bldg. 2261. Initially all surfaces indicated the presence of mold. Immediately after treatment, only a "very few" total spore count was present at Sample Locations \#6 and \#7. Sample Location \#8 showed $\leq 1+$. No surface mold was detected at any surface sample location for the 3-month sampling event. Mold levels at all sample locations remained zero thru the 6-month sampling event. 
Table 10. Surface sampling results for Bldg. 2261.

\begin{tabular}{|l|l|c|c|c|c|c|}
\hline ID & Fungal Type & Before & After & 1 Month & 3 Month & 6 Month \\
\hline$\# 6$ & Cladosporium & $2+$ & 0 & 0 & 0 & 0 \\
\cline { 2 - 7 } & Penicillium/ Aspergillus & 0 & 0 & 0 & 0 & 0 \\
\cline { 2 - 7 } & Total & very few & very few & 0 & 0 & 0 \\
\hline$\# 7$ & Cladosporium & $2+$ & 0 & 0 & 0 & 0 \\
\cline { 2 - 7 } & Penicillium/ Aspergillus & 0 & 0 & 0 & 0 & 0 \\
\cline { 2 - 7 } & Total & very few & very few & 0 & 0 & 0 \\
\hline \multirow{3}{*}{8} & Cladosporium & $2+$ & $<1+$ & 0 & 0 & 0 \\
\cline { 2 - 7 } & Penicillium/ Aspergillus & 0 & 0 & 0 & 0 & 0 \\
\cline { 2 - 7 } & Total & very few & very few & very few & 0 & 0 \\
\hline
\end{tabular}

\subsection{Barracks-Bldg. 6733}

\subsubsection{Air sampling}

Table 11 lists the results of the air sampling at Bldg. 6733. Each sampling location was allocated a representative number of square feet within the total square footage treated. A summation of the \#spores $/ \mathrm{m}^{3}$ at each sampling location within the building, multiplied by the associated square feet for each sample, divided by the total number of square feet treated provides a weighted average of the sampling results, which comprises a single value for each fungal type for each building. The efficacy of the treatment is determined by comparing these values to the background levels at the time of each sampling. Values at or below background levels indicate that the treatment and/or removal was (and continues to be) effective.

Table 11. Air sampling results (\#spores/m³) for Bldg. 6733.

\begin{tabular}{|c|c|c|c|c|c|c|c|}
\hline ID & $\begin{array}{l}\text { Associated } \\
\text { Area (sq ft) }\end{array}$ & Fungal Type & Before & After & 1 Month & 3 Month & 6 Month \\
\hline \multirow{3}{*}{$\# 10$} & \multirow{3}{*}{1458} & Stachybotrys/ Chaetomium & 0 & 0 & 0 & 0 & 0 \\
\hline & & Total & 110000 & 210000 & 1200 & 430 & 93 \\
\hline & & Hyphal Fragments & 0 & 0 & 0 & 0 & 0 \\
\hline \multirow{3}{*}{ \#11 } & \multirow{3}{*}{768} & Stachybotrys/ Chaetomium & 0 & 0 & 0 & 0 & 0 \\
\hline & & Total & 1400000 & 100000 & 1100 & 480 & 210 \\
\hline & & Hyphal Fragments & 150 & 0 & 0 & 0 & 0 \\
\hline \multirow{3}{*}{$\# 12$} & \multirow{3}{*}{648} & Stachybotrys/ Chaetomium & 80 & 0 & 0 & 0 & 0 \\
\hline & & Total & 3400 & 13000 & 3300 & 1200 & 10000 \\
\hline & & Hyphal Fragments & 110 & 53 & 0 & 0 & 0 \\
\hline \multirow{3}{*}{ \#17 } & \multirow{3}{*}{ Outdoor/ Background } & Stachybotrys/ Chaetomium & 0 & 0 & 0 & 0 & 0 \\
\hline & & Total & 3100 & 3100 & 8100 & 14000 & 20000 \\
\hline & & Hyphal Fragments & 0 & 0 & 0 & 0 & 0 \\
\hline
\end{tabular}


Note that between the 3-month and 6-month sampling events, the Fort Campbell personnel and/or contractor personnel began to renovate the building. It is very likely that ingress and egress of these personnel had some effect on the existing conditions. However, no monitoring or oversight was in place to account for these differing site conditions. This may explain the drastic increase of total spores for the 6-month sampling event (1200 spores $/ \mathrm{m}^{3}$ to 10,000 spores $/ \mathrm{m}^{3}$ ) at Location \#12 (basement of the administrative area) in Bldg. 6733, which represents a 733\% increase while the background spore count only increased by $42.9 \%$. Despite this drastic increase, indoor levels were only $50 \%$ of the background level suggesting continued treatment.

\subsubsection{Surface sampling}

Table 12 lists the results of the surface sampling at Bldg. 6733. Initially all surfaces indicated the presence of mold, specifically cladosporium. One month after treatment, only a "very few" total spore count was present at Sample Locations \#14 and \#16. Three months following treatment, "very few" were reported for Location \#14 and no mold spores were present at Locations \#15 and \#16. Levels appeared to be rising between the 3-month and 6-month sampling events. During this time, the building's interior changed from an uninhabited space to a space undergoing renovation. This change in environment, combined with added occupancy and ongoing renovation activities, created varying conditions that could have triggered an increased total spore count. Continued monitoring and sampling could have provided greater insight as to whether this trend would continue. Unfortunately, the scope of work did not include this continued work.

Table 12. Surface sampling results for Bldg. 6733.

\begin{tabular}{|c|l|c|c|c|c|c|}
\hline ID & \multicolumn{1}{|c|}{ Fungal Type } & Before & After & 1 Month & 3 Month & 6 Month \\
\hline$\# 14$ & Cladosporium & $2+$ & 0 & 0 & 0 & 0 \\
\cline { 2 - 7 } & Penicillium/ Aspergillus & 0 & 0 & 0 & 0 & 0 \\
\cline { 2 - 7 } & Total & very few & very few & very few & very few & very few \\
\hline \multirow{3}{*}{ 15 } & Cladosporium & $4+$ & 0 & 0 & 0 & 0 \\
\cline { 2 - 7 } & Penicillium/ Aspergillus & 0 & $2+$ & 0 & 0 & 0 \\
\cline { 2 - 7 } & Total & 0 & very few & 0 & 0 & very few \\
\hline \multirow{3}{*}{16} & Cladosporium & $4+$ & $<1+$ & 0 & 0 & 0 \\
\cline { 2 - 7 } & Penicillium/ Aspergillus & 0 & 0 & 0 & 0 & 0 \\
\cline { 2 - 7 } & Total & 0 & very few & very few & 0 & few \\
\hline
\end{tabular}




\section{Conclusions and Recommendations}

The sampling results of this demonstration indicate that the dry-fog technology was capable of rapidly eliminating mold spores. Results also showed that the second step of the dry-fog technology's (application of EVERpure) continued to reduce mold spore levels over time; with minor exceptions, while total spore counts outdoors increased throughout the demonstration, indoor levels continued to decrease. However, the increased values for hyphal fragments at Locations \#3 and \#4 in Bldg. 2261 during the 6-month sampling event did not conclusively confirm the technology's treatment effectiveness beyond 6 months.

This work concluded that the dry-fog technology provides rapid and quantifiable improvements to indoor air quality, and also that it drastically reduces exposure of Army building occupants and maintenance workers to harmful chemicals resulting from current mold remediation practices.

Current rough estimates for application of the dry-fog technology are approximately $\$ 1.00 / \mathrm{sq} \mathrm{ft}$. Actual costs would deviate from this estimate dependent on location and proximity to the vendor. It is likely that an installation could achieve additional cost savings by acquiring an in-house capability to apply the treatment. Implementing the dry-fog technology at Army installations would be relatively straightforward. The equipment could be purchased and the vendor engaged to train personnel in its use. Ongoing inhouse training could be planned to disseminate additional treatment systems across Army installations. Treatment systems could be purchased for use at each installation, or for use on a regional basis to share the technology across installations in neighboring geographic locations.

It is recommended that additional demonstration(s) be completed for longer periods (12 to 24 months). Ideally the demonstration(s) would be conducted in buildings where the indoor environment and building usage would remain constant throughout the demonstration period. It is also recommended that the dry-fog technology be demonstrated at new construction sites where it could potentially serve as a preventive measure. 


\section{References}

EMLab P\&K IAQ. 2012. Pocket Reference Guide. $7^{\text {th }}$ ed. Marlton, NJ: EMLab P\&K, pp. 22-23, 29, 37-38. https://www.emlab.com/s/services/pocketguide.html

Hirschi, S. D., and D. L. Herron. 2017. Lab looks at "dry-fog' technology for mold remediation, prevention. Public Works Digest, Vol. XXIX, No. 4, p. 30.

Kung'u, Jackson. 2016. How to Interpret Laboratory Results for Airborne Fungal (Mould) Samples. Mississauga, Ontario: Mold \& Bacteria Consulting Laboratories (MBL) Inc. http://pahi.org/sitebuildercontent/sitebuilderfiles/howtointerpretlaboratoryresultsforairbornefungalmoldsamples.pdf

Naval Facilities Engineering Command (NAVFAC). 2011. Mold Remediation. Unified Facilities Guide Specification (UFGS) 028500.00 20. Washington, DC: NAVFAC (Preparing Agency). https://www.wbdg.org/FFC/DOD/UFGS/UFGS\%2002\%2085\%2000.00\%2020.pdf

Peacock Enterprises. 2017. Common Particles and Their Sizes in Microns. http://airqualityindoors.com/particlesizes.htm

Stephenson, L. D., J. L. Lattimore, and K. M. Torrey. 2011. Prevention of Toxic Molds in Army Facilities Using Surface-Applied Biocides. ERDC/CERL TR-11-22. Champaign, IL: Engineer Research and Development Center, Construction Engineering Research Laboratory (ERDC-CERL).

U.S. Army Public Health Command (USAPHC). 2002. Army Facilities Management Information Document on Mold Remediation Issues. TG 277. https://usaphc.amedd.army.mil/PHC\%20Resource\%20Library/TG277.pdf

Vavrin, John L., and William J. Stein. 2015. Mold Remediation and Recommendations to Resolve Other Major Issues in Concrete B-Huts at Bagram Air Field, Afghanistan. ERDC/CERL TR-15-27. Champaign, IL: ERDC-CERL. 


\section{Acronyms and Abbreviations}

$\begin{array}{ll}\text { Term } & \text { Definition } \\ \text { ACSIM } & \text { Assistant Chief of Staff for Installation Management } \\ \text { ANSI } & \text { American National Standards Institute } \\ \text { ASTM } & \text { American Society for Testing and Materials } \\ \text { CEERD } & \text { US Army Corps of Engineers, Engineer Research and Development } \\ & \text { Center } \\ \text { CERL } & \text { Construction Engineering Research Laboratory } \\ \text { DoD } & \text { U.S. Department of Defense } \\ \text { ERDC } & \text { U.S. Army Engineer Research and Development Center } \\ \text { ERDC-CERL } & \text { Engineer Research and Development Center, Construction Engineering } \\ & \text { Research Laboratory } \\ \text { FEMA } & \text { Federal Emergency Management Agency } \\ \text { HVAC } & \text { Heating, Ventilating, and Air-Conditioning } \\ \text { IAQ } & \text { Indoor Air Quality } \\ \text { ID } & \text { Identification } \\ \text { ITTP } & \text { Installation Technology Transition Program } \\ \text { LLC } & \text { Limited Liability Company } \\ \text { MBL } & \text { Mold \& Bacteria Consulting Laboratories } \\ \text { MEL } & \text { Maximum Exposure Limit } \\ \text { MSDS } & \text { Material Safety Data Sheet (OSHA) } \\ \text { NAVFAC } & \text { Naval Facilities Engineering Command } \\ \text { NSN } & \text { National Supply Number } \\ \text { OACSIM } & \text { Office of the Assistant Chief of Staff for Installation Management } \\ \text { OMB } & \text { Office of Management and Budget } \\ \text { PMO } & \text { Program Management Office } \\ \text { PPE } & \text { Personal Protective Equipment } \\ \text { SAR } & \text { Same As Report } \\ \text { SF } & \text { Standard Form } \\ \text { TR } & \text { Technical Report } \\ \text { UFGS } & \text { Unified Facilities Guide Specification } \\ \text { USACE } & \text { U.S. Army Corps of Engineers } \\ \text { USEPA } & \text { U.S. Environmental Protection Agency } \\ \text { USAPHC } & \text { U.S. Army Public Health Command } \\ \end{array}$




\section{Appendix A: Material Safety Data Sheets for INSTAPure and EVERPure}

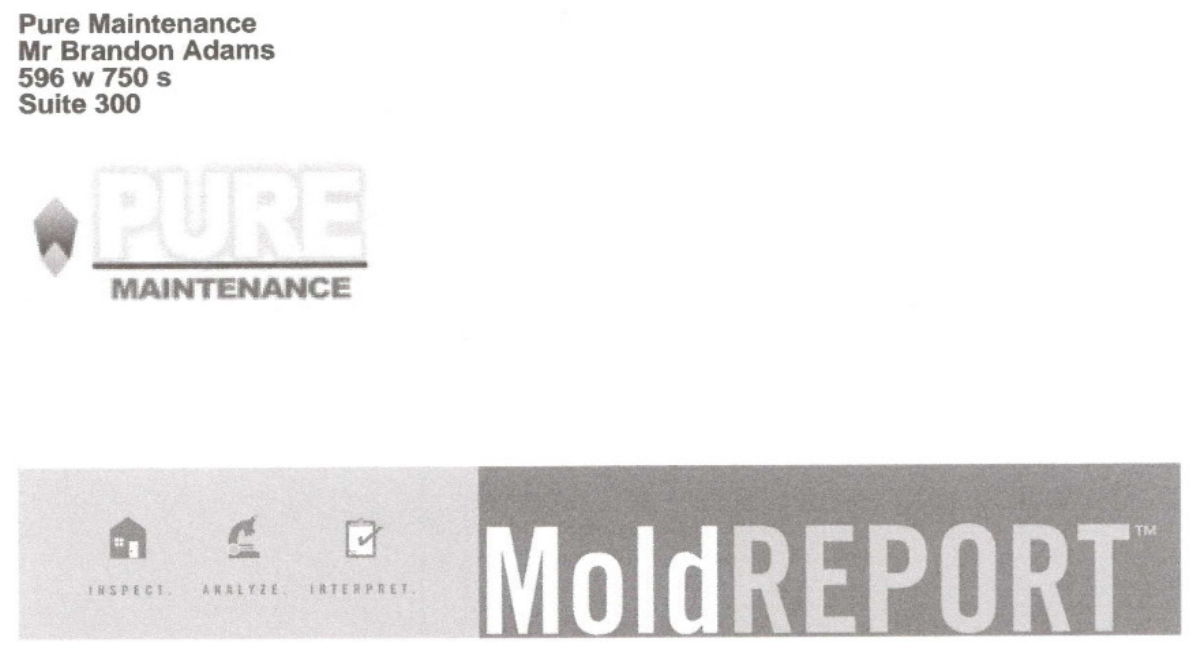

EMLab P \& $K$

Www.MoidREPORT.com

info@MoldREPORT.com

Approved by:

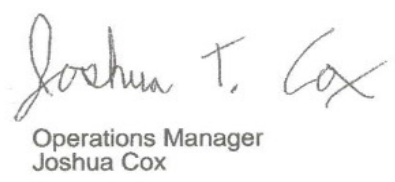

Dates of Analysis:

MoldReport Direct exam: 03-27-2017

Service SOPs: MoldReport Direct exam (EM-MY-S-1039)

AlHA-LAP, LLC accredited service, Lab ID \#102297

All samples were received in acceptable condition unless noted in the Report Comments portion in the body of the report. Due to
the nature of the analyses performed, field blank correction of results is not applied. The results relate only to the items tested.
EMLab P\&K ("the Company") shall have no liability to the client or the client's customer with respect to decisions or
recommendations made, actions taken or courses of conduct implemented by either the client or the client's customer as a result
of or based upon the Test Results. In no event shall the Company be liable to the client with respect to the Test Results except for
the Company's own willful misconduct or gross negligence nor shall the Company be liable for incidental or consequential
damages or lost profits or revenues to the fullest extent such liability may be disclaimed by law, even if the Company has been
advised of the possibility of such damages, lost profits or lost revenues. In no event shall the Company's liability with respect to
the Test Results exceed the amount paid to the Company by the client therefor.
Aerotech Laboratories, Inc
EMLab ID: 1699368, Page 1 of 2 
Client: Pure Maintenance

Contact: Mr Brandon Adams

Project: Mess Hall Fort Campbell Before Treatment

Date of Sampling: 03-20-2017

Date of Receipt: 03-24-2017

Date of Report: 03-27-2017

MoldREPORT

EMLab P \& K

1501 West Knudsen Drive, Phoenix, AZ 85027 (800) 651-4802 Fax (623) 780-7695

\section{Laboratory Results}

MoldREPORT: Spore Trap Analysis

\begin{tabular}{|c|c|c|c|c|c|c|}
\hline Location: & \multicolumn{2}{|c|}{$\begin{array}{c}1: \\
\# 1 \text { North West Corner BT }\end{array}$} & \multicolumn{2}{|c|}{$\begin{array}{c}2: \\
\text { \#2 Middle West Side BT }\end{array}$} & \multicolumn{2}{|c|}{$\begin{array}{c}\text { 3: } \\
\text { \#3 South East Kitchen BT }\end{array}$} \\
\hline Comments (see below) & \multicolumn{2}{|c|}{ None } & \multicolumn{2}{|c|}{ None } & \multicolumn{2}{|c|}{ None } \\
\hline Lab ID-Versiont: & \multicolumn{2}{|c|}{$7921457-1$} & \multicolumn{2}{|c|}{$7921458-1$} & \multicolumn{2}{|c|}{$7921459-1$} \\
\hline Analysis Date: & \multicolumn{2}{|c|}{$03 / 27 / 2017$} & \multicolumn{2}{|c|}{$03 / 27 / 2017$} & \multicolumn{2}{|c|}{$03 / 27 / 2017$} \\
\hline Spore types detected: & raw ct. & per $\mathrm{m} 3$ & raw ct. & per $\mathrm{m} 3$ & raw ct. & per $\mathrm{m} 3$ \\
\hline Aureobasidium & - & - & - & - & - & - \\
\hline Basidiospores & - & - & - & - & - & - \\
\hline Chaetomium & - & - & - & - & - & - \\
\hline Cladosporium & 345 & 18,000 & 175 & 47,000 & 203 & 110,000 \\
\hline Fusarium & - & - & - & - & - & - \\
\hline Penicillium/Aspergillus types & 1 & 53 & 18 & 960 & - & - \\
\hline Stachybotrys & - & - & - & - & - & - \\
\hline Trichoderma & - & - & - & - & - & - \\
\hline Ulocladium & - & - & - & - & - & - \\
\hline Others & 6 & 320 & 7 & 370 & 2 & 110 \\
\hline 8 Total: & & 19,000 & & 48,000 & & 110,000 \\
\hline \multicolumn{7}{|l|}{ Additional Information: } \\
\hline Hyphal fragments & \multicolumn{2}{|c|}{1,300} & \multicolumn{2}{|c|}{2,000} & \multicolumn{2}{|c|}{2,700} \\
\hline Skin cells & \multicolumn{2}{|c|}{$80-4,000$} & \multicolumn{2}{|c|}{$80-4,000$} & \multicolumn{2}{|c|}{$80-4,000$} \\
\hline Pollen & \multicolumn{2}{|c|}{53} & \multicolumn{2}{|c|}{$<13$} & \multicolumn{2}{|c|}{110} \\
\hline Background debris $(1-4) \dagger$ & \multicolumn{2}{|c|}{3} & \multicolumn{2}{|c|}{4} & \multicolumn{2}{|r|}{3} \\
\hline Limit of detection & \multicolumn{2}{|c|}{13} & \multicolumn{2}{|c|}{13} & \multicolumn{2}{|c|}{13} \\
\hline Sample volume (liters) & \multicolumn{2}{|c|}{75} & \multicolumn{2}{|c|}{75} & \multicolumn{2}{|c|}{75} \\
\hline
\end{tabular}

Comments:

Basidiospores (basidiomycetes): Basidiospores are extremely common outdoors and originate from fungi in gardens, forests, and woodlands. It is rare for the source of basidiospores to be indoors. However, basidiospores may be an indicator of wood decay.

Cladosporium: One of the most commonly found molds outdoors and frequently found growing indoors. Spores from Cladosporium are generally present in outdoor and indoor air, even in relatively clean, mold-growth-free, indoor environments. Levels vary based upon activity levels, weather conditions, dustiness, outside air exchange rates, and other factors.

Penicillium/Aspergillus types: Penicllium and Aspergillus are among the most common molds found growing both indoors and outdoors (even in relatively clean, mold-growth-free, indoor environments). Levels vary based upon activity levels, dustiness, weather conditions, outside air exchange rates, and other factors.

Stachybotrys and other marker types: Certain types of mold, such as Aureobasidium, Chaetomium, Fusarium, Trichoderma, and Ulocladium, are generally found in very low numbers outdoors. Consequently their presence indoors, even in relatively low numbers, is often an indication that these molds are originating from growth indoors. When present, these mold types are often the clearest indicator of a mold problem.

Others: Molds in the "Others" category are generally found outdoors in moderate numbers, and are therefore not considered markers of indoor growth.

\footnotetext{
¥ A "Version" indicated by -" $\mathrm{x}$ " after the Lab ID\# with a value greater than 1 indicates a sample with amended data. The revision number is reflected by the value of " $\mathrm{x}$ ". + Background debris is an indication of the amounts of non-biological particulate matter present on the slide (dust in the air) and is graded from 1 to 4 with 4
indicating the largest amounts.

The analytical sensitivity is the spores $/ \mathrm{m}^{\wedge} 3$ divided by the raw count, expressed in spores $/ \mathrm{m}^{\wedge} 3$. The limit of detection is the analytical sensitivity (in spores $/ \mathrm{m}^{\wedge} 3$ ) multiplied by the sample volume (in liters) divided by 1000 liters.
}

$\$$ Total has been rounded to two significant figures to reflect analytical precision.

Rev02 03/11

Aerotech Laboratories, Inc

EMLab ID: 1699377 , Page 2 of 3 
Client: Pure Maintenance

Contact: Mr Brandon Adams

Project: Mess Hall Fort Campbell Before Treatment

MoldREPORT

Date of Sampling: 03-20-2017

Date of Receipt: 03-24-2017

Date of Report: 03-27-2017

EMLab P \& K

1501 West Knudsen Drive, Phoenix, AZ 85027

(800) 651-4802 Fax (623) 780-7695

Laboratory Results

MoldREPORT: Spore Trap Analysis

\begin{tabular}{|c|c|c|c|c|}
\hline Location: & \multicolumn{2}{|c|}{$\begin{array}{c}4: \\
\text { \#4 South West Office BT }\end{array}$} & \multicolumn{2}{|c|}{$\begin{array}{c}\text { 9: } \\
\text { Outside \#5 Air Sample }\end{array}$} \\
\hline Comments (see below) & \multicolumn{2}{|c|}{ None } & \multicolumn{2}{|c|}{ None } \\
\hline Lab ID-Version $\ddagger$ : & \multicolumn{2}{|c|}{$7921460-1$} & \multicolumn{2}{|c|}{$7921461-1$} \\
\hline Analysis Date: & \multicolumn{2}{|c|}{$03 / 27 / 2017$} & \multicolumn{2}{|c|}{$03 / 27 / 2017$} \\
\hline Spore types detected: & raw ct. & per $\mathrm{m} 3$ & raw ct. & per $\mathrm{m} 3$ \\
\hline Aureobasidium & - & - & - & - \\
\hline Basidiospores & 10 & 530 & 2 & 110 \\
\hline Chaetomium & - & - & - & - \\
\hline Cladosporium & 33 & 1,800 & 9 & 480 \\
\hline Fusarium & - & - & - & - \\
\hline Penicillium/Aspergillus types & 69 & 3,700 & - & - \\
\hline Stachybotrys & 390 & 520,000 & - & - \\
\hline Trichoderma & - & - & - & - \\
\hline Ulocladium & - & - & - & - \\
\hline Others & 2 & 110 & - & - \\
\hline 8 Total: & & 530,000 & & 590 \\
\hline \multicolumn{5}{|l|}{ Additional Information: } \\
\hline Hyphal fragments & \multicolumn{2}{|c|}{5,800} & \multicolumn{2}{|c|}{110} \\
\hline Skin cells & \multicolumn{2}{|c|}{$80-4,000$} & \multicolumn{2}{|c|}{$13-67$} \\
\hline Pollen & \multicolumn{2}{|c|}{$<13$} & \multicolumn{2}{|c|}{370} \\
\hline Background debris $(1-4) \dagger$ & \multicolumn{2}{|c|}{2} & \multicolumn{2}{|c|}{1} \\
\hline Limit of detection & \multicolumn{2}{|c|}{13} & \multicolumn{2}{|c|}{13} \\
\hline Sample volume (liters) & \multicolumn{2}{|c|}{75} & \multicolumn{2}{|c|}{75} \\
\hline
\end{tabular}

Comments:

Basidiospores (basidiomycetes): Basidiospores are extremely common outdoors and originate from fungi in gardens, forests, and woodlands. It is rare for the source of basidiospores to be indoors. However, basidiospores may be an indicator of wood decay.

Cladosporium: One of the most commonly found molds outdoors and frequently found growing indoors. Spores from Cladosporium are generally present in outdoor and indoor air, even in relatively clean, mold-growth-free, indoor environments. Levels vary based upon activity

Penicillium/Aspergillus types: Penicllium and Aspergillus are among the most common molds found growing both indoors and outdoors (even in relatively clean, mold-growth-free, indoor environments). Levels vary based upon activity levels, dustiness, weather conditions, outside air exchange rates, and other factors.

Stachybotrys and other marker types: Certain types of mold, such as Aureobasidium, Chaetomium, Fusarium, Trichoderma, and Ulocladium, are generally found in very low numbers outdoors. Consequently their presence indoors, even in relatively low numbers, is often an indication that these molds are originating from growth indoors. When present, these mold types are often the clearest indicator of a mold problem.

Others: Molds in the "Others" category are generally found outdoors in moderate numbers, and are therefore not considered markers of indoor growth.

¥ A "Version" indicated by -" $\mathrm{x}$ " after the Lab ID\# with a value greater than 1 indicates a sample with amended data. The revision number is reflected by the value of " $\mathrm{x}$ "

Background debris is an indication of the amounts of non-biological particulate matter present on the slide (dust in the air) and is graded from 1 to 4 with 4 indicating the largest amounts.

The analytical sensitivity is the spores $/ \mathrm{m}^{\wedge} 3$ divided by the raw count, expressed in spores $/ \mathrm{m}^{\wedge} 3$. The limit of detection is the analytical sensitivity (in spores $/ \mathrm{m}^{\wedge} 3$ ) nultiplied by the sample volume (in liters) divided by 1000 liters.

\& Total has been rounded to two significant figures to reflect analytical precision.

Rev0203/11

Aerotech Laboratories, Inc

EMLab ID: 1699377, Page 3 of 3 
Client: Pure Maintenance

Contact: Mr Brandon Adams

Project: Mess Hall Fort Campbell Before Treatment

Date of Sampling: 03-20-2017

Date of Receipt: 03-24-2017

Date of Report: 03-27-2017
MoldREPORT EMLab P \& K

1501 West Knudsen Drive, Phoenix, AZ 85027 (800) 651-4802 Fax (623) 780-7695

\begin{tabular}{|c|c|c|c|}
\hline \multicolumn{4}{|c|}{$\begin{array}{l}\text { Laboratory Results } \\
\text { pic Examination }\end{array}$} \\
\hline Location: & $\begin{array}{l}\text { 5: \#6 Middle Divider } \\
\text { Wall }\end{array}$ & 6: \#7 West Wall & 7: \#8 Kitchen Wall \\
\hline Comments (see below): & None & None & None \\
\hline Lab ID-Version‡: & $7921454-1$ & $7921455-1$ & $7921456-1$ \\
\hline \multicolumn{4}{|c|}{$\begin{array}{l}\text { Spore types present (indicative } \\
\text { of mold growth)§: }\end{array}$} \\
\hline Aureobasidium & - & - & - \\
\hline Basidiospores & - & - & - \\
\hline Chaetomium & - & - & - \\
\hline Cladosporium & $2+$ & $2+$ & $2+$ \\
\hline Fusarium & - & - & - \\
\hline Lumber mold $\dagger$ & - & - & - \\
\hline Penicillium/Aspergillus types & - & - & - \\
\hline Stachybotrys & $=$ & - & - \\
\hline Trichoderma & - & - & - \\
\hline Ulocladium & - & - & - \\
\hline \multicolumn{4}{|l|}{$\begin{array}{l}\text { Spore types present (not } \\
\text { indicative of mold growth)§: }\end{array}$} \\
\hline All spore types & Very few & Very few & Very few \\
\hline \multicolumn{4}{|l|}{ Other particles detected§: } \\
\hline Skin cells & Very few & Very few & Very few \\
\hline Pollen & - & - & - \\
\hline $\begin{array}{l}\text { Background Debris and/or } \\
\text { Description }{ }^{* *} \text { : }\end{array}$ & Moderate & Moderate & Moderate \\
\hline
\end{tabular}

Comments: None

Basidiomycetes: Commonly found outdoors. Occasionally may grow indoors, mostly as agents of wood decay.

Cladosporium: One of the most commonly found molds outdoors and frequently found growing indoors.

Penicillium/Aspergillus types: Penicllium and Aspergillus are among the most common molds found growing both indoors and out.

Stachybotrys and other marker types: Certain types of mold, such as Aureobasidium, Chaetomium, Fusarium, Trichoderma, and Ulocladium, are generally found in very low numbers outdoors. Consequently their presence indoors, even in relatively low numbers, is often an indication that these molds are originating from growth indoors. When present, these mold types are often the clearest indicator of a mold problem.

tLumber mold: Fungi in the Ceratocystis/Ophiostoma group are commonly called "Lumber mold". Lumber mold is present on the wood framing of

most homes that are built with lumber. Their presence alone is not indicative of an indoor water problem. as Scant, Moderate, Heavy, or Very Heavy. Very heavy background debris may obscure visibility for the analyst. Some sample types are not

graded for background debris, in which case a brief description of the material is reported.. reflected by the value of " $x$ ".

The limit of detection is < 1+ when mold growth is detected. \$All readers are advised to refer to the document "Understa

Aerotech Laboratories, Inc 
Client: Pure Maintenance

Contact: Mr Brandon Adams

Date of Sampling: 03-21-2017

Date of Receipt: 03-24-2017

Date of Report: 03-27-2017

MoldREPORT

EMLab P \& K

1501 West Knudsen Drive, Phoenix, AZ 85027

(800) 651-4802 Fax (623) 780-7695

\section{Laboratory Results}

MoldREPORT: Spore Trap Analysis

\begin{tabular}{|c|c|c|c|c|}
\hline Location: & \multicolumn{2}{|c|}{$\begin{array}{c}1: \\
\text { \#10 North West Classroom BT }\end{array}$} & \multicolumn{2}{|c|}{$\begin{array}{c}2: \\
\text { \#11 Mens Bathroom BT }\end{array}$} \\
\hline Comments (see below) & \multicolumn{2}{|c|}{ None } & \multicolumn{2}{|c|}{ None } \\
\hline Lab ID-Version‡: & \multicolumn{2}{|c|}{$7921647-1$} & \multicolumn{2}{|c|}{$7921648-1$} \\
\hline Analysis Date: & \multicolumn{2}{|c|}{$03 / 27 / 2017$} & \multicolumn{2}{|c|}{$03 / 27 / 2017$} \\
\hline Spore types detected: & raw ct. & per $\mathrm{m} 3$ & raw ct. & per $\mathrm{m} 3$ \\
\hline Aureobasidium & - & - & - & - \\
\hline Basidiospores & - & - & 1 & 53 \\
\hline Chaetomium & - & - & - & - \\
\hline Cladosporium & 2,672 & $1,400,000$ & 1 & 53 \\
\hline Fusarium & - & - & - & - \\
\hline Penicillium/Aspergillus types & - & - & 197 & 110,000 \\
\hline Stachybotrys & - & - & - & - \\
\hline Trichoderma & - & - & - & - \\
\hline Ulocladium & 3 & 40 & - & - \\
\hline Others & 1 & 13 & 1 & 53 \\
\hline 8 Total: & & $1,400,000$ & & 110,000 \\
\hline \multicolumn{5}{|l|}{ Additional Information: } \\
\hline Hyphal fragments & \multicolumn{2}{|c|}{160} & \multicolumn{2}{|c|}{110} \\
\hline Skin cells & \multirow{2}{*}{\multicolumn{2}{|c|}{$13-67$}} & \multicolumn{2}{|c|}{$80-4,000$} \\
\hline Pollen & \multirow{2}{*}{\multicolumn{2}{|c|}{$\frac{<13}{1}$}} & \multicolumn{2}{|c|}{$<13$} \\
\hline Background debris (1-4) $\dagger$ & & & \multicolumn{2}{|c|}{2} \\
\hline Limit of detection & \multicolumn{2}{|c|}{13} & & \\
\hline Sample volume (liters) & \multicolumn{2}{|c|}{75} & \multicolumn{2}{|c|}{75} \\
\hline
\end{tabular}

lume (liters)

Comments:

Basidiospores (basidiomycetes): Basidiospores are extremely common outdoors and originate from fungi in gardens, forests, and woodlands. It is rare for the source of basidiospores to be indoors. However, basidiospores may be an indicator of wood decay.

Cladosporium: One of the most commonly found molds outdoors and frequently found growing indoors. Spores from Cladosporium are generally present in outdoor and indoor air, even in relatively clean, mold-growth-free, indoor environments. Levels vary based upon activity levels, weather conditions, dustiness, outside air exchange rates, and other factors.

Penicillium/Aspergillus types: Penicllium and Aspergillus are among the most common molds found growing both indoors and outdoors (even in relatively clean, mold-growth-free, indoor environments). Levels vary based upon activity levels, dustiness, weather conditions, outside air exchange rates, and other factors.

Stachybotrys and other marker types: Certain types of mold, such as Aureobasidium, Chaetomium, Fusarium, Trichoderma, and Ulocladium, are generally found in very low numbers outdoors. Consequently their presence indoors, even in relatively low numbers, is often an indication that these molds are originating from growth indoors. When present, these mold types are often the clearest indicator of a mold problem.

Others: Molds in the "Others" category are generally found outdoors in moderate numbers, and are therefore not considered markers of indoor growth.

\footnotetext{
¥ A "Version" indicated by -" $x$ " after the Lab ID\# with a value greater than 1 indicates a sample with amended data. The revision number is reflected by the value of " $\mathrm{x}$ ".

Background debris is an indication of the amounts of non-biological particulate matter present on the slide (dust in the air) and is graded from 1 to 4 with 4 indicating the largest amounts.

The analytical sensitivity is the spores $/ \mathrm{m}^{\wedge} 3$ divided by the raw count, expressed in spores $/ \mathrm{m}^{\wedge} 3$. The limit of detection is the analytical sensitivity (in spores $/ \mathrm{m}^{\wedge} 3$ ) multiplied by the sample volume (in liters) divided by 1000 liters.
}

\$ Total has been rounded to two significant figures to reflect analytical precision.

Rev0203/11

Aerotech Laboratories, Inc

EMLab ID: 1699368, Page 2 of 3 
Client: Pure Maintenance

Contact: Mr Brandon Adams

Project: Hammer Head Fort Campbell Before Treatment

Date of Sampling: 03-21-2017

Date of Receipt: 03-24-2017

Date of Report: 03-27-2017
MoldREPORT

EMLab P \& K

1501 West Knudsen Drive, Phoenix, AZ 85027
(800) 651-4802 Fax (623) 780-7695

\section{Laboratory Results}

MoldREPORT: Spore Trap Analysis

\begin{tabular}{|c|c|c|c|c|}
\hline Location: & \multicolumn{2}{|c|}{$\begin{array}{c}\text { 3: } \\
\text { \#12 Basement BT }\end{array}$} & \multicolumn{2}{|c|}{$\begin{array}{c}10: \\
\text { \#17 Outside Hammerhead }\end{array}$} \\
\hline Comments (see below) & \multicolumn{2}{|c|}{ None } & \multicolumn{2}{|c|}{ None } \\
\hline Lab ID-Versiont: & \multicolumn{2}{|c|}{$7921649-1$} & \multicolumn{2}{|c|}{$7921650-1$} \\
\hline Analysis Date: & \multicolumn{2}{|c|}{$03 / 27 / 2017$} & \multicolumn{2}{|c|}{$03 / 27 / 2017$} \\
\hline Spore types detected: & raw ct. & per $\mathrm{m} 3$ & raw ct. & per $\mathrm{m} 3$ \\
\hline Aureobasidium & - & - & - & - \\
\hline Basidiospores & 19 & 1,000 & 23 & 1,200 \\
\hline Chaetomium & 1 & 13 & - & - \\
\hline Cladosporium & 30 & 1,600 & 22 & 1,200 \\
\hline Fusarium & - & - & - & - \\
\hline Penicillium/Aspergillus types & 8 & 430 & 4 & 210 \\
\hline Stachybotrys & 5 & 67 & - & - \\
\hline Trichoderma & - & - & - & - \\
\hline Ulocladium & - & - & - & - \\
\hline Others & 6 & 320 & 10 & 530 \\
\hline 8 Total: & & 3,400 & & 3,100 \\
\hline \multicolumn{5}{|l|}{ Additional Information: } \\
\hline Hyphal fragments & \multicolumn{2}{|c|}{110} & \multicolumn{2}{|c|}{-} \\
\hline Skin cells & \multicolumn{2}{|c|}{$80-4,000$} & \multicolumn{2}{|c|}{$13-67$} \\
\hline Pollen & \multicolumn{2}{|c|}{$<13$} & \multicolumn{2}{|c|}{110} \\
\hline Background debris (1-4)† & \multicolumn{2}{|c|}{2} & \multicolumn{2}{|c|}{2} \\
\hline Limit of detection & \multirow{2}{*}{\multicolumn{2}{|c|}{13}} & \multicolumn{2}{|c|}{13} \\
\hline Sample volume (liters) & & & \multicolumn{2}{|c|}{75} \\
\hline
\end{tabular}

volume (liters)

(800) 651-4802 Fax (623) 780-769.

Comments:
Basidiospores (basidiomycetes): Basidiospores are extremely common outdoors and originate from fungi in gardens, forests, and woodlands. It is rare for the source of basidiospores to be indoors. However, basidiospores may be an indicator of wood decay.

Cladosporium: One of the most commonly found molds outdoors and frequently found growing indoors. Spores from Cladosporium are generally present in outdoor and indoor air, even in relatively clean, mold-growth-free, indoor environments. Levels vary based upon activity levels, weather conditions, dustiness, outside air exchange rates, and other factors.

Penicillium/Aspergillus types: Penicllium and Aspergillus are among the most common molds found growing both indoors and outdoors (even in relatively clean, mold-growth-free, indoor environments). Levels vary based upon activity levels, dustiness, weather conditions, outside air exchange rates, and other factors.

Stachybotrys and other marker types: Certain types of mold, such as Aureobasidium, Chaetomium, Fusarium, Trichoderma, and Ulocladium, are generally found in very low numbers outdoors. Consequently their presence indoors, even in relatively low numbers, is often an indication that these molds are originating from growth indoors. When present, these mold types are often the clearest indicator of a mold problem.

Others: Molds in the "Others" category are generally found outdoors in moderate numbers, and are therefore not considered markers of indoor growth.

\footnotetext{
† A "Version" indicated by -"x" after the Lab ID\# with a value greater than 1 indicates a sample with amended data. The revision number is reflected by the value of "x". Background debris is an indication of the amounts of non-biological particulate matter present on the slide (dust in the air) and is graded from 1 to 4 with 4 indicating the largest amounts.

The analytical sensitivity is the spores $/ \mathrm{m}^{\wedge} 3$ divided by the raw count, expressed in spores $/ \mathrm{m}^{\wedge} 3$. The limit of detection is the analytical sensitivity (in spores/ $\mathrm{m}^{\wedge} 3$ ) multiplied by the sample volume (in liters) divided by 1000 liters.
}

$\S$ Total has been rounded to two significant figures to reflect analytical precision.

Rev02 03/11

Aerotech Laboratories, Inc

EMLab ID: 1699368, Page 3 of 3 
Client: Pure Maintenance

Contact: Mr Brandon Adams

Project: Hammer Head Fort Campbell Before Treatment

Date of Sampling: 03-21-2017

Date of Receipt: 03-24-2017

Date of Report: 03-27-2017
MoldREPORT EMLab P \& K

1501 West Knudsen Drive, Phoenix, AZ 85027 (800) 651-4802 Fax (623) 780-7695

MoldREPORT: Direct Microscopic Examination

\begin{tabular}{|c|c|c|c|}
\hline Location: & $\begin{array}{l}\text { 5: \#14 Basement } \\
\text { South Wall BT }\end{array}$ & $\begin{array}{l}\text { 6: \#15 Mens Bathroom } \\
\text { South Wall BT }\end{array}$ & $\begin{array}{c}\text { 7: \#16 North Wall Of } \\
\text { North West Classroom } \\
\text { BT }\end{array}$ \\
\hline Comments (see below): & None & None & None \\
\hline Lab ID-Versionł: & $7921644-1$ & $7921645-1$ & $7921646-1$ \\
\hline \multicolumn{4}{|c|}{$\begin{array}{l}\text { Spore types present (indicative } \\
\text { of mold growth)§: }\end{array}$} \\
\hline Aureobasidium & - & - & - \\
\hline Basidiospores & - & - & - \\
\hline Chaetomium & - & - & - \\
\hline Cladosporium & $2+$ & - & $4+$ \\
\hline Fusarium & - & - & - \\
\hline Lumber mold $t$ & - & - & - \\
\hline Penicillium/Aspergillus types & - & $4+$ & - \\
\hline Stachybotrys & - & - & - \\
\hline Trichoderma & - & - & - \\
\hline Ulocladium & - & - & - \\
\hline \multicolumn{4}{|l|}{$\begin{array}{l}\text { Spore types present (not } \\
\text { indicative of mold growth)§: }\end{array}$} \\
\hline All spore types & Very few & - & - \\
\hline \multicolumn{4}{|l|}{ Other particles detected§: } \\
\hline Skin cells & Very few & - & - \\
\hline Pollen & - & - & - \\
\hline $\begin{array}{l}\text { Background Debris and/or } \\
\text { Description**: }\end{array}$ & Light & Scant & None \\
\hline
\end{tabular}

Basidiomycetes: Commonly found outdoors. Occasionally may grow indoors, mostly as agents of wood decay.

Cladosporium: One of the most commonly found molds outdoors and frequently found growing indoors.

Penicillium/Aspergillus types: Penicllium and Aspergillus are among the most common molds found growing both indoors and out.

Stachybotrys and other marker types: Certain types of mold, such as Aureobasidium, Chaetomium, Fusarium, Trichoderma, and Ulocladium, are generally found in very low numbers outdoors. Consequently their presence indoors, even in relatively low numbers, is often an indication that these molds are originating from growth indoors. When present, these mold types are often the clearest indicator of a mold problem.

†Lumber mold: Fungi in the Ceratocystis/Ophiostoma group are commonly called "Lumber mold". Lumber mold is present on the wood framing of most homes that are built with lumber. Their presence alone is not indicative of an indoor water problem.

*Background debris is an indication of the amounts of non-biological particulate matter present. This background material is graded and described as Scant, Moderate, Heavy, or Very Heavy. Very heavy background debris may obscure visibility for the analyst. Some sample types are not graded for background debris, in which case a brief description of the material is reported.

7 " "Version" indicated by - " $\mathrm{x"}$ after the Lab ID\# with a value greater than 1 indicates a sample with amended data. The revision number is reflected by the value of " $x$ " $x$ "

SAll readers are advised to refer to the document "Understanding Direct Microscopic Examination Results" which is available at our website,

Aerotech Laboratories, Inc

EMLab ID: 1699368, Page 2 of 2 
Client: Pure Maintenance

Contact: Mr Brandon Adams

Project: Mess Hall Fort Campbell After Treatment

Date of Sampling: 03-20-2017

Date of Receipt: 03-24-2017

Date of Report: 03-27-2017
MoldREPORT

EMLab P \& K

1501 West Knudsen Drive, Phoenix, AZ 85027 (800) 651-4802 Fax (623) 780-7695

\section{MoldREPORT: Spore Trap Analysis}

\begin{tabular}{|c|c|c|c|c|c|c|}
\hline Location: & \multicolumn{2}{|c|}{$\begin{array}{c}1: \\
\text { \#1A North West Corner } \\
\text { AT }\end{array}$} & \multicolumn{2}{|c|}{$\begin{array}{c}2: \\
\text { \#2A Middle West Side } \\
\text { AT }\end{array}$} & \multicolumn{2}{|c|}{$\begin{array}{c}\text { 3: } \\
\text { \#3A South East Kitchen } \\
\text { AT }\end{array}$} \\
\hline Comments (see below) & \multicolumn{2}{|c|}{ None } & \multicolumn{2}{|c|}{ None } & \multicolumn{2}{|c|}{ None } \\
\hline Lab ID-Version $\$:$ & \multicolumn{2}{|c|}{$7925892-1$} & \multicolumn{2}{|c|}{$7925893-1$} & \multicolumn{2}{|c|}{$7925894-1$} \\
\hline Analysis Date: & \multicolumn{2}{|c|}{$03 / 27 / 2017$} & \multicolumn{2}{|c|}{$03 / 27 / 2017$} & \multicolumn{2}{|c|}{$03 / 27 / 2017$} \\
\hline Spore types detected: & raw ct. & per $\mathrm{m} 3$ & raw ct. & per $\mathrm{m} 3$ & raw ct. & per $\mathrm{m} 3$ \\
\hline Aureobasidium & - & - & - & - & - & - \\
\hline Basidiospores & 2 & 110 & 2 & 110 & 2 & 110 \\
\hline Chaetomium & - & - & - & - & - & - \\
\hline Cladosporium & 92 & 4,900 & 42 & 2,200 & 25 & 1,300 \\
\hline Fusarium & - & - & - & - & - & - \\
\hline Penicillium/Aspergillus types & 185 & 9,900 & 187 & 10,000 & 198 & 11,000 \\
\hline Stachybotrys & - & - & - & - & - & - \\
\hline Trichoderma & - & - & - & - & - & - \\
\hline Ulocladium & - & - & - & - & - & - \\
\hline Others & - & - & 2 & 110 & - & - \\
\hline \& Total: & & 15,000 & & 12,000 & & 12,000 \\
\hline \multicolumn{7}{|l|}{ Additional Information: } \\
\hline Hyphal fragments & \multicolumn{2}{|c|}{430} & \multicolumn{2}{|c|}{-} & \multicolumn{2}{|c|}{-} \\
\hline Skin cells & \multirow{2}{*}{\multicolumn{2}{|c|}{$80-4,000$}} & \multicolumn{2}{|c|}{$13-67$} & \multicolumn{2}{|c|}{$80-4,000$} \\
\hline Pollen & \multirow{2}{*}{\multicolumn{2}{|c|}{$\frac{53}{2}$}} & \multicolumn{2}{|c|}{$<13$} & \multirow{2}{*}{\multicolumn{2}{|c|}{$\frac{<13}{2}$}} \\
\hline Background debris $(1-4) \dagger$ & \multirow{2}{*}{\multicolumn{2}{|c|}{$\frac{2}{13}$}} & \multicolumn{2}{|c|}{1} & \multirow{2}{*}{\multicolumn{2}{|c|}{$\frac{2}{13}$}} \\
\hline Limit of detection & & & \multirow{2}{*}{\multicolumn{2}{|c|}{$\begin{array}{l}13 \\
75 \\
\end{array}$}} & & \\
\hline Sample volume (liters) & \multicolumn{2}{|c|}{75} & & & \multicolumn{2}{|c|}{75} \\
\hline
\end{tabular}

Sample volume (liters)

Comments: $\quad$.

Basidiospores (basidiomycetes): Basidiospores are extremely common outdoors and originate from fungi in gardens
is rare for the source of basidiospores to be indoors. However, basidiospores may be an indicator of wood decay.

Cladosporium: One of the most commonly found molds outdoors and frequently found growing indoors. Spores from Cladosporium are generally present in outdoor and indoor air, even in relatively clean, mold-growth-free, indoor environments. Levels vary based upon activity levels, weather conditions, dustiness, outside air exchange rates, and other factors.

Penicillium/Aspergillus types: Penicllium and Aspergillus are among the most common molds found growing both indoors and outdoors (even in relatively clean, mold-growth-free, indoor environments). Levels vary based upon activity levels, dustiness, weather conditions, outside air exchange rates, and other factors.

Stachybotrys and other marker types: Certain types of mold, such as Aureobasidium, Chaetomium, Fusarium, Trichoderma, and Ulocladium, Stachyours outdoors. Consequently their presence indoors, even in relatively low numbers, is often an indicatio that these molds are originating from growth indoors. When present, these mold types are often the clearest indicator of a mold problem.

Others: Molds in the "Others" category are generally found outdoors in moderate numbers, and are therefore not considered markers of indoor growth.

¥ A "Version" indicated by -"x" after the Lab ID\# with a value greater than 1 indicates a sample with amended data. The revision number is reflected by the value of " $\mathrm{x}$ ". indicating the largest amounts.

The analytical sensitivity is the spores $/ \mathrm{m}^{\wedge} 3$ divided by the raw count, expressed in spores $/ \mathrm{m}^{\wedge} 3$. The limit of detection is the analytical sensitivity (in spores $/ \mathrm{m}^{\wedge} 3$ ) multiplied by the sample volume (in liters) divided by 1000 liters.

$\S$ Total has been rounded to two significant figures to reflect analytical precision.

Rev02 03/11

EMLab ID: 1699379, Page 2 of 3 
Client: Pure Maintenance

Contact: Mr Brandon Adams

Project: Mess Hall Fort Campbell After Treatment

MoldREPORT

Date of Sampling: 03-20-2017

Date of Receipt: 03-24-2017

Date of Report: 03-27-2017

\section{EMLab P \& K}

1501 West Knudsen Drive, Phoenix, AZ 85027 (800) $651-4802$ Fax (623) 780-7695

MoldREPORT: Spore Trap Analysis

\begin{tabular}{|c|c|c|c|c|}
\hline Location: & \multicolumn{2}{|c|}{$\begin{array}{c}\text { 4: } \\
\text { \#4A South West Office AT }\end{array}$} & \multicolumn{2}{|c|}{$\begin{array}{c}\text { 9: } \\
\text { Outside \#5 Air Sample }\end{array}$} \\
\hline Comments (see below) & \multicolumn{2}{|c|}{ None } & \multicolumn{2}{|c|}{ A } \\
\hline Lab ID-Versionț: & \multicolumn{2}{|c|}{$7925895-1$} & \multicolumn{2}{|c|}{$7921561-0$} \\
\hline Analysis Date: & \multicolumn{2}{|c|}{$03 / 27 / 2017$} & \multicolumn{2}{|c|}{$03 / 27 / 2017$} \\
\hline Spore types detected: & raw ct. & per $\mathrm{m} 3$ & raw ct. & per $\mathrm{m} 3$ \\
\hline Aureobasidium & - & - & - & - \\
\hline Basidiospores & - & - & 2 & 110 \\
\hline Chaetomium & - & - & - & - \\
\hline Cladosporium & 11 & 590 & 9 & 480 \\
\hline Fusarium & - & - & - & - \\
\hline Penicillium/Aspergillus types & 197 & 11,000 & - & - \\
\hline Stachybotrys & - & - & - & - \\
\hline Trichoderma & - & - & - & - \\
\hline Ulocladium & - & - & - & - \\
\hline Others & - & - & - & - \\
\hline 8 Total: & & 11,000 & & 590 \\
\hline \multicolumn{5}{|l|}{ Additional Information: } \\
\hline Hyphal fragments & \multicolumn{2}{|c|}{-} & \multicolumn{2}{|c|}{110} \\
\hline Skin cells & \multicolumn{2}{|c|}{$13-67$} & \multicolumn{2}{|c|}{$13-67$} \\
\hline Pollen & \multicolumn{2}{|c|}{$<13$} & \multicolumn{2}{|c|}{370} \\
\hline Background debris $(1-4) \dagger$ & \multicolumn{2}{|c|}{1} & \multicolumn{2}{|c|}{1} \\
\hline Limit of detection & \multirow{2}{*}{\multicolumn{2}{|c|}{$\frac{13}{75}$}} & \multicolumn{2}{|c|}{13} \\
\hline Sample volume (liters) & & 75 & \multicolumn{2}{|c|}{75} \\
\hline
\end{tabular}

Sample volume (liters)

Comments: A) Data transferred from EMLab ID: 1699377 at client's request.

Basidiospores (basidiomycetes): Basidiospores are extremely common outdoors and originate from fungi in gardens, forests, and woodlands. It is rare for the source of basidiospores to be indoors. However, basidiospores may be an indicator of wood decay.

Cladosporium: One of the most commonly found molds outdoors and frequently found growing indoors. Spores from Cladosporium are generally present in outdoor and indoor air, even in relatively clean, mold-growth-free, indoor environments. Levels vary based upon activity
levels, weather conditions, dustiness, outside air exchange rates, and other factors.

Penicillium/Aspergillus types: Penicllium and Aspergillus are among the most common molds found growing both indoors and outdoors (even in relatively clean, mold-growth-free, indoor environments). Levels vary based upon activity levels, dustiness, weather conditions, outside air exchange rates, and other factors.

Stachybotrys and other marker types: Certain types of mold, such as Aureobasidium, Chaetomium, Fusarium, Trichoderma, and Ulocladium, are generally found in very low numbers outdoors. Consequently their presence indoors, even in relatively low numbers, is often an indication that these molds are originating from growth indoors. When present, these mold types are often the clearest indicator of a mold problem.

Others: Molds in the "Others" category are generally found outdoors in moderate numbers, and are therefore not considered markers of indoor growth. $\ddagger$ A "Version" indicated by -"x" after the Lab ID\# with a value greater than 1 indicates a sample with amended data. The revision number is reflected by the
value of " $\mathrm{x}$ ".
† Background debris is an indication of the amounts of non-biological particulate matter present on the slide (dust in the air) and is graded from 1 to 4 with 4
indicating the largest amounts.
The analytical sensitivity is the spores $/ \mathrm{m}^{\wedge} 3$ divided by the raw count, expressed in spores $/ \mathrm{m}^{\wedge} 3$. The limit of detection is the analytical sensitivity (in spores $/ \mathrm{m}^{\wedge} 3$ )
multiplied by the sample volume (in liters) divided by 1000 liters.

$\S$ Total has been rounded to two significant figures to reflect analytical precision.

Rev02 03/11

Aerotech Laboratories, Inc 
Client: Pure Maintenance Contact: Mr Brandon Adams Project: Mess Hall Fort Campbell After Treatment

MoldREPORT EMLab P \& K Date of Sampling: 03-20-2017

Date of Receipt: 03-24-2017

Date of Report: 03-27-2017

1501 West Knudsen Drive, Phoenix, AZ 85027 (800) $651-4802$ Fax (623) 780-7695

\begin{tabular}{|c|c|c|c|}
\hline \multicolumn{4}{|c|}{$\begin{array}{l}\text { Laboratory Results } \\
\text { pic Examination }\end{array}$} \\
\hline Location: & $\begin{array}{l}\text { 5: \#6A Middle Divider } \\
\text { Wall AT }\end{array}$ & 6: \#7A West Wall AT & 7: \#8A Kitchen Wall AT \\
\hline Comments (see below): & None & None & A \\
\hline Lab ID-Versionł: & $7921486-1$ & $7921487-1$ & $7921488-1$ \\
\hline \multicolumn{4}{|c|}{$\begin{array}{l}\text { Spore types present (indicative } \\
\text { of mold growth)§: }\end{array}$} \\
\hline Aureobasidium & - & - & - \\
\hline Basidiospores & - & - & - \\
\hline Chaetomium & - & - & - \\
\hline Cladosporium & - & - & $<1+$ \\
\hline Fusarium & - & - & - \\
\hline Lumber mold $\dagger$ & - & - & - \\
\hline Penicillium/Aspergillus types & - & - & - \\
\hline Stachybotrys & - & - & - \\
\hline Trichoderma & - & - & - \\
\hline Ulocladium & - & - & - \\
\hline \multicolumn{4}{|l|}{$\begin{array}{l}\text { Spore types present (not } \\
\text { indicative of mold growth)§: }\end{array}$} \\
\hline All spore types & Very few & Very few & Very few \\
\hline \multicolumn{4}{|l|}{ Other particles detected§: } \\
\hline Skin cells & Very few & Very few & Very few \\
\hline Pollen & - & - & - \\
\hline $\begin{array}{l}\text { Background Debris and/or } \\
\text { Description }{ }^{* *} \text { : }\end{array}$ & Light & Light & Light \\
\hline
\end{tabular}

Comments: A) A few Penicillium/Aspergillus group spores detected.

Basidiomycetes: Commonly found outdoors. Occasionally may grow indoors, mostly as agents of wood decay.

Cladosporium: One of the most commonly found molds outdoors and frequently found growing indoors.

Penicillium/Aspergillus types: Penicllium and Aspergillus are among the most common molds found growing both indoors and out.

Stachybotrys and other marker types: Certain types of mold, such as Aureobasidium, Chaetomium, Fusarium, Trichoderma, and Ulocladium, are generally found in very low numbers outdoors. Consequently their presence indoors, even in relatively low numbers, is often an indication that these molds are originating from growth indoors. When present, these mold types are often the clearest indicator of a mold problem.

†Lumber mold: Fungi in the Ceratocystis/Ophiostoma group are commonly called "Lumber mold". Lumber mold is present on the wood framing of most homes that are built with lumber. Their presence alone is not indicative of an indoor water problem.

"Background debris is an indication of the amounts of non-biological particulate matter present. This background material is graded and described as Scant, Moderate, Heavy, or Very Heavy. Very heavy background debris may obscure visibility for the analyst. Some sample types are not

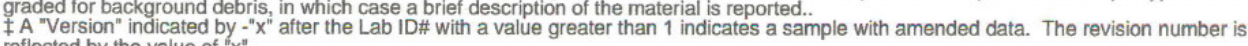
reflected by the value of " $x$ ".

§All readers are advised to refer to the document "Understanding Direct Microscopic Examination Results" which is available at our website, www.moldreport.com, or by request from the laboratory.

Aerotech Laboratories, Inc 
Client: Pure Maintenance

Contact: Mr Brandon Adams

Project: Hammer Head Fort Campbell After Treatment

Date of Sampling: 03-21-2017

Date of Receipt: 03-24-2017

Date of Report: 03-27-2017
MoldREPORT EMLab P \& K

1501 West Knudsen Drive, Phoenix, AZ 85027 (800) 651-4802 Fax (623) 780-7695

\section{Laboratory Results}

MoldREPORT: Spore Trap Analysis

\begin{tabular}{|c|c|c|c|c|}
\hline Location: & \multicolumn{2}{|c|}{$\begin{array}{c}1: \\
\text { \#10A North West Classroom AT }\end{array}$} & \multicolumn{2}{|c|}{$\begin{array}{c}\text { 2: } \\
\text { \#11A Mens Bathroom AT }\end{array}$} \\
\hline Comments (see below) & \multicolumn{2}{|c|}{ None } & \multicolumn{2}{|c|}{ None } \\
\hline Lab ID-Version $\$:$ & \multicolumn{2}{|c|}{$7921657-1$} & \multicolumn{2}{|c|}{$7921658-1$} \\
\hline Analysis Date: & \multicolumn{2}{|c|}{$03 / 27 / 2017$} & \multicolumn{2}{|c|}{$03 / 27 / 2017$} \\
\hline Spore types detected: & raw ct. & per $\mathrm{m} 3$ & raw ct. & per $\mathrm{m} 3$ \\
\hline Aureobasidium & - & - & - & - \\
\hline Basidiospores & - & - & - & - \\
\hline Chaetomium & - & - & - & - \\
\hline Cladosporium & - & - & - & - \\
\hline Fusarium & - & - & - & - \\
\hline Penicillium/Aspergillus types & 388 & 210,000 & 191 & 100,000 \\
\hline Stachybotrys & - & - & - & - \\
\hline Trichoderma & - & - & - & - \\
\hline Ulocladium & - & - & - & - \\
\hline Others & - & - & 1 & 53 \\
\hline 8 Total: & & 210,000 & & 100,000 \\
\hline \multicolumn{5}{|l|}{ Additional Information: } \\
\hline Hyphal fragments & \multicolumn{2}{|c|}{-} & \multicolumn{2}{|c|}{-} \\
\hline Skin cells & \multicolumn{2}{|c|}{$13-67$} & \multicolumn{2}{|c|}{$13-67$} \\
\hline Pollen & \multicolumn{2}{|c|}{$<13$} & \multicolumn{2}{|c|}{$<13$} \\
\hline Background debris $(1-4) \dagger$ & \multicolumn{2}{|c|}{1} & \multicolumn{2}{|c|}{2} \\
\hline Limit of detection & \multirow{2}{*}{\multicolumn{2}{|c|}{13}} & \multicolumn{2}{|c|}{13} \\
\hline Sample volume (liters) & & & & \\
\hline
\end{tabular}

Sample volume (liters)

Comments:
Basidiospores (basidiomycetes): Basidiospores are extremely common outdoors and originate from fungi in gardens, forests, and woodlands. It is rare for the source of basidiospores to be indoors. However, basidiospores may be an indicator of wood decay.

Cladosporium: One of the most commonly found molds outdoors and frequently found growing indoors. Spores from Cladosporium are generally present in outdoor and indoor air, even in relatively clean, mold-growth-free, indoor environments. Levels vary based upon activity levels, weather conditions, dustiness, outside air exchange rates, and other factors.

Penicillium/Aspergillus types: Penicllium and Aspergillus are among the most common molds found growing both indoors and outdoors (even in relatively clean, mold-growth-free, indoor environments). Levels vary based upon activity levels, dustiness, weather conditions, outside air exchange rates, and other factors.

Stachybotrys and other marker types: Certain types of mold, such as Aureobasidium, Chaetomium, Fusarium, Trichoderma, and Ulocladium, are generally found in very low numbers outdoors. Consequently their presence indoors, even in relatively low numbers, is often an indication that these molds are originating from growth indoors. When present, these mold types are often the clearest indicator of a mold problem.

Others: Molds in the "Others" category are generally found outdoors in moderate numbers, and are therefore not considered markers of indoor growth.

A "Version" indicated by -" $x$ " after the Lab ID\# with a value greater than 1 indicates a sample with amended data. The revision number is reflected by the value of " $\mathrm{x}$ ".

† Background debris is an indication of the amounts of non-biological particulate matter present on the slide (dust in the air) and is graded from 1 to 4 with 4 indicating the largest amounts.

The analytical sensitivity is the spores $/ \mathrm{m}^{\wedge} 3$ divided by the raw count, expressed in spores $/ \mathrm{m}^{\wedge} 3$. The limit of detection is the analytical sensitivity (in spores $/ \mathrm{m}^{\wedge} 3$ ) multiplied by the sample volume (in liters) divided by 1000 liters.

$\S$ Total has been rounded to two significant figures to reflect analytical precision.

Rev02 03/11

Aerotech Laboratories, Inc

EMLab ID: 1699373, Page 2 of 3 
Client: Pure Maintenance

Contact: Mr Brandon Adams

Project: Hammer Head Fort Campbell After Treatment

Date of Sampling: 03-21-2017

Date of Receipt: 03-24-2017

Date of Report: 03-27-2017

\section{Laboratory Results}

MoldREPORT: Spore Trap Analysis

\begin{tabular}{|c|c|c|c|c|}
\hline Location: & \multicolumn{2}{|c|}{$\begin{array}{c}3: \\
\text { \#12A Basement AT }\end{array}$} & \multicolumn{2}{|c|}{$\begin{array}{c}10: \\
\text { \#17 Outside Hammerhead }\end{array}$} \\
\hline Comments (see below) & \multicolumn{2}{|c|}{ None } & \multicolumn{2}{|c|}{ A } \\
\hline Lab ID-Version $\neq:$ & \multicolumn{2}{|c|}{$7921659-1$} & \multicolumn{2}{|c|}{$7921660-0$} \\
\hline Analysis Date: & \multicolumn{2}{|c|}{$03 / 27 / 2017$} & \multicolumn{2}{|c|}{$03 / 27 / 2017$} \\
\hline Spore types detected: & raw ct. & per $\mathrm{m} 3$ & raw ct. & per $\mathrm{m} 3$ \\
\hline Aureobasidium & - & - & - & - \\
\hline Basidiospores & - & - & 23 & 1,200 \\
\hline Chaetomium & - & - & - & - \\
\hline Cladosporium & 189 & 10,000 & 22 & 1,200 \\
\hline Fusarium & - & - & - & - \\
\hline Penicillium/Aspergillus types & 53 & 2,800 & 4 & 210 \\
\hline Stachybotrys & - & - & - & - \\
\hline Trichoderma & - & - & - & - \\
\hline Ulocladium & - & - & - & - \\
\hline Others & - & - & 10 & 530 \\
\hline \& Total: & & 13,000 & & 3,100 \\
\hline \multicolumn{5}{|l|}{ Additional Information: } \\
\hline Hyphal fragments & \multicolumn{2}{|c|}{53} & \multicolumn{2}{|c|}{-} \\
\hline Skin cells & \multicolumn{2}{|c|}{$13-67$} & \multicolumn{2}{|c|}{$13-67$} \\
\hline Pollen & \multicolumn{2}{|c|}{$<13$} & \multicolumn{2}{|c|}{110} \\
\hline Background debris $(1-4) \dagger$ & \multicolumn{2}{|c|}{2} & \multicolumn{2}{|c|}{2} \\
\hline Limit of detection & \multicolumn{2}{|c|}{13} & \multicolumn{2}{|c|}{13} \\
\hline Sample volume (liters) & \multicolumn{2}{|c|}{75} & \multicolumn{2}{|c|}{75} \\
\hline
\end{tabular}

Comments: A) Data transferred from EMLab ID: 1699368 at client's request.

Basidiospores (basidiomycetes): Basidiospores are extremely common outdoors and originate from fungi in gardens, forests, and woodlands. It is rare for the source of basidiospores to be indoors. However, basidiospores may be an indicator of wood decay.

Cladosporium: One of the most commonly found molds outdoors and frequently found growing indoors. Spores from Cladosporium are Cladosporium: One of the most commonly found inolelatively clean, mold-growth-free, indoor environments. Levels vary based upon activity levels, weather conditions, dustiness, outside air exchange rates, and other factors.

Penicillium/Aspergillus types: Penicllium and Aspergillus are among the most common molds found growing both indoors and outdoors (even in relatively clean, mold-growth-free, indoor environments). Levels vary based upon activity levels, dustiness, weather conditions, outside air exchange rates, and other factors.

Stachybotrys and other marker types: Certain types of mold, such as Aureobasidium, Chaetomium, Fusarium, Trichoderma, and Ulocladium, are generally found in very low numbers outdoors. Consequently their presence indoors, even in relatively low numbers, is often an indication that these molds are originating from growth indoors. When present, these mold types are often the clearest indicator of a mold problem.

Others: Molds in the "Others" category are generally found outdoors in moderate numbers, and are therefore not considered markers of indoor growth.

I A "Version" indicated by -" $\mathrm{x}$ " after the Lab ID\# with a value greater than 1 indicates a sample with amended data. The revision number is reflected by the value of " $\mathrm{x}$ ". indicating the largest amounts.

The analytical sensitivity is the spores $/ \mathrm{m}^{\wedge} 3$ divided by the raw count, expressed in spores $/ \mathrm{m}^{\wedge} 3$. The limit of detection is the analytical sensitivity (in spores $/ \mathrm{m}^{\wedge} 3$ ) multiplied by the sample volume (in liters) divided by 1000 liters.

$\S$ Total has been rounded to two significant figures to reflect analytical precision.

Rev02 03/11

Aerotech Laboratories, Inc

EMLab ID: 1699373, Page 3 of 3 
Client: Pure Maintenance

Contact: Mr Brandon Adams

Project: Hammer Head Fort Campbell After Treatment

Date of Sampling: 03-21-2017

Date of Receipt: 03-24-2017

Date of Report: 03-27-2017
MoldREPORT EMLab P \& K

1501 West Knudsen Drive, Phoenix, AZ 85027 (800) 651-4802 Fax (623) 780-7695

\begin{tabular}{|c|c|c|c|}
\hline \multicolumn{4}{|c|}{$\begin{array}{l}\text { Laboratory Results } \\
\text { MoldREPORT: Direct Microscopic Examination }\end{array}$} \\
\hline Location: & $\begin{array}{l}\text { 5: \#14A Basement } \\
\text { South Wall AT }\end{array}$ & $\begin{array}{c}\text { 6: \#15A Mens } \\
\text { Bathroom South Wall } \\
\text { AT }\end{array}$ & $\begin{array}{c}\text { 7: \#16A North Wall Of } \\
\text { North West Classroom } \\
\text { AT }\end{array}$ \\
\hline Comments (see below): & None & None & None \\
\hline Lab ID-Versionł: & $7921654-1$ & $7921655-1$ & $7921656-1$ \\
\hline \multicolumn{4}{|l|}{$\begin{array}{l}\text { Spore types present (indicative } \\
\text { of mold growth)§: }\end{array}$} \\
\hline Aureobasidium & - & - & - \\
\hline Basidiospores & - & - & - \\
\hline Chaetomium & - & - & - \\
\hline Cladosporium & - & - & $<1+$ \\
\hline Fusarium & - & - & - \\
\hline Lumber mold $t$ & - & - & - \\
\hline Penicillium/Aspergillus types & - & $2+$ & - \\
\hline Stachybotrys & - & - & - \\
\hline Trichoderma & - & - & - \\
\hline Ulocladium & - & - & - \\
\hline \multicolumn{4}{|l|}{$\begin{array}{l}\text { Spore types present (not } \\
\text { indicative of mold growth)§: }\end{array}$} \\
\hline All spore types & Very few & Very few & Very few \\
\hline \multicolumn{4}{|l|}{ Other particles detected§: } \\
\hline Skin cells & Very few & Very few & Few \\
\hline Pollen & - & - & - \\
\hline $\begin{array}{l}\text { Background Debris and/or } \\
\text { Description }{ }^{* *} \text { : }\end{array}$ & Scant & Light & Light \\
\hline
\end{tabular}

Description ${ }^{* *}$ :

Comments: None

Basidiomycetes: Commonly found outdoors. Occasionally may grow indoors, mostly as agents of wood decay.

Cladosporium: One of the most commonly found molds outdoors and frequently found growing indoors.

Penicillium/Aspergillus types: Penicllium and Aspergillus are among the most common molds found growing both indoors and out.

Stachybotrys and other marker types: Certain types of mold, such as Aureobasidium, Chaetomium, Fusarium, Trichoderma, and Ulocladium, are generally found in very low numbers outdoors. Consequently their presence indoors, even in relatively low numbers, is often an indication that these molds are originating from growth indoors. When present, these mold types are often the clearest indicator of a mold problem.

tLumber mold: Fungi in the Ceratocystis/Ophiostoma group are commonly called "Lumber mold". Lumber mold is present on the wood framing of

most homes that are built with lumber. Their presence alone is not indicative of an indoor water problem. as Scant, Moderate. Heavy, or Very Heavy. Very heavy background debris may obscure visibility for the analyst. Some sample types are not graded for background debris, in which case a brief description of the material is reported.

$¥$ A "Version" indicated by " " $\mathrm{x}$ " after the Lab ID\# with a value greater than 1 indicates a sample with amended data. The revision number is reflected by the value of " $x$ ". The limit of detection is < $1+$ when mold growth is detected.
§All readers are advised to refer to the document "Understanding Direct Microscopic Examination Results" which is available at our website,

www.moldreport.com, or by request from the laboratory.

Aerotech Laboratories, Inc 
Pure Maintenance

Mr Brandon Adams

596 w $750 \mathrm{~s}$

Suite 300

Bountiful, UT 84010 USA

(801) 529-2976
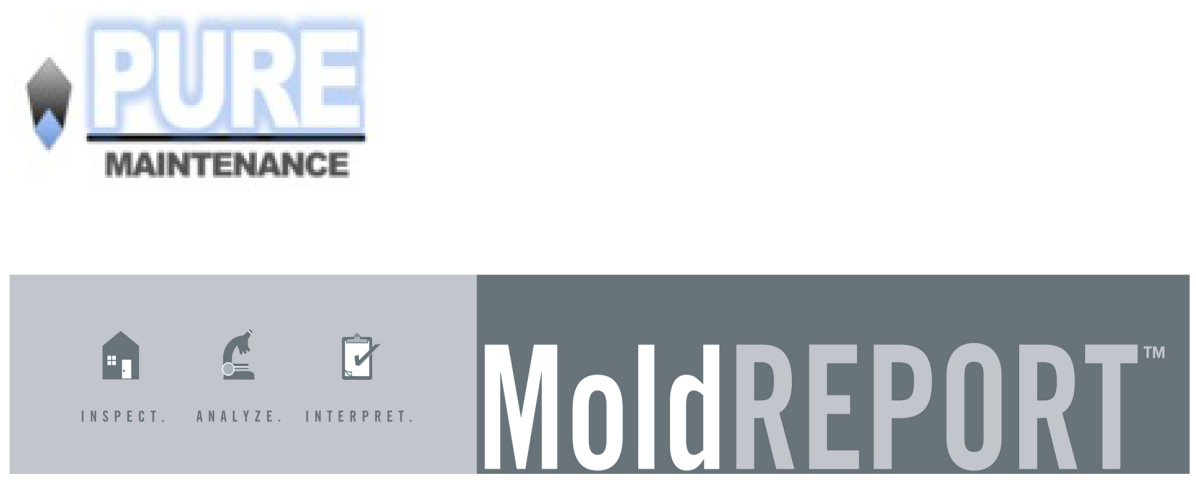

EMLab P \& K

WWW.MoldREPORT.com

info@MoldREPORT.com

Approved by:

Dates of Analysis:

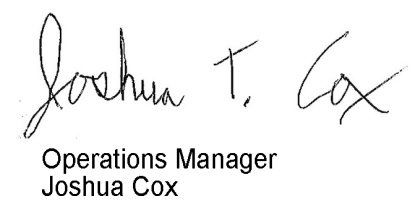

MoldReport Spore trap: 04-28-2017

Service SOPs: MoldReport Spore trap (EM-MY-S-1038)

AlHA-LAP, LLC accredited service, Lab ID \#102297

All samples were received in acceptable condition unless noted in the Report Comments portion in the body of the report. Due to the nature of the analyses performed, field blank correction of results is not applied. The results relate only to the items tested.

The analytical sensitivity is the spores $/ \mathrm{m}^{\wedge} 3$ divided by the raw count, expressed in spores $/ \mathrm{m}^{\wedge} 3$. The limit of detection is the analytical sensitivity (in spores $/ \mathrm{m}^{\wedge} 3$ ) multiplied by the sample volume (in liters) divided by 1000 liters.

EMLab P\&K ("the Company") shall have no liability to the client or the client's customer with respect to decisions or recommendations made, actions taken or courses of conduct implemented by either the client or the client's customer as a result of or based upon the Test Results. In no event shall the Company be liable to the client with respect to the Test Results except for the Company's own willful misconduct or gross negligence nor shall the Company be liable for incidental or consequential damages or lost profits or revenues to the fullest extent such liability may be disclaimed by law, even if the Company has been advised of the possibility of such damages, lost profits or lost revenues. In no event shall the Company's liability with respect to the Test Results exceed the amount paid to the Company by the client therefor. 
Client: Pure Maintenance

Contact: Mr Brandon Adams

MoldREPORT

Project: Mess Hall 1 Month Post Treatment

EMLab P \& K

Date of Sampling: 04-25-2017

Date of Receipt: 04-27-2017

Date of Report: 04-28-2017

1501 West Knudsen Drive, Phoenix AZ 85027

(800) $651-4802 \mathrm{Fax}(623) 780-7695$

MoldREPORT: Spore Trap Analysis

\begin{tabular}{|c|c|c|c|c|c|c|}
\hline Location: & \multicolumn{2}{|c|}{$\begin{array}{c}1: \\
\text { Northwest Corner A1 }\end{array}$} & \multicolumn{2}{|c|}{$\begin{array}{c}2: \\
\text { Middle West Side A1 }\end{array}$} & \multicolumn{2}{|c|}{$\begin{array}{c}3: \\
\text { South West Office Al }\end{array}$} \\
\hline Comments (see below) & \multicolumn{2}{|c|}{ None } & \multicolumn{2}{|c|}{ None } & \multicolumn{2}{|c|}{ None } \\
\hline Lab ID-Version:: & \multicolumn{2}{|c|}{$8012803-1$} & \multicolumn{2}{|c|}{$8012804-1$} & \multicolumn{2}{|c|}{$8012805-1$} \\
\hline Analysis Date: & \multicolumn{2}{|c|}{$04 / 28 / 2017$} & \multicolumn{2}{|c|}{$04 / 28 / 2017$} & \multicolumn{2}{|c|}{$04 / 28 / 2017$} \\
\hline Spore types detected: & raw ct. & per m3 & raw ct. & per m3 & raw ct. & per m3 \\
\hline Aureobasidium & - & - & - & - & - & - \\
\hline Basidiospores & 5 & 270 & 10 & 530 & 14 & 750 \\
\hline Chaetomium & - & - & - & - & 1 & 13 \\
\hline Cladosporium & 13 & 690 & 7 & 370 & - & - \\
\hline Fusarium & - & - & - & - & - & - \\
\hline Penicillium/Aspergillus types & 5 & 270 & 5 & 270 & 17 & 910 \\
\hline Stachybotrys & - & - & - & - & - & - \\
\hline Trichoderma & - & - & - & - & - & - \\
\hline Ulocladium & - & - & - & - & - & - \\
\hline Others & 7 & 370 & 4 & 210 & 6 & 320 \\
\hline § Total: & & 1.600 & & 1.400 & & 2,000 \\
\hline \multicolumn{7}{|l|}{ Additional Information: } \\
\hline Hyphal fragments & \multicolumn{2}{|c|}{ 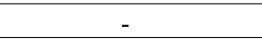 } & \multicolumn{2}{|c|}{ 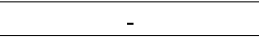 } & \multicolumn{2}{|c|}{-} \\
\hline Skin cells & \multicolumn{2}{|c|}{$80-4,000$} & \multicolumn{2}{|c|}{$80-4,000$} & \multicolumn{2}{|c|}{$80-4,000$} \\
\hline Pollen & \multicolumn{2}{|c|}{$<13$} & \multicolumn{2}{|c|}{$<13$} & \multicolumn{2}{|c|}{53} \\
\hline Background debris $(1-4) \dagger$ & \multicolumn{2}{|c|}{2} & \multicolumn{2}{|c|}{2} & \multicolumn{2}{|c|}{2} \\
\hline Limit of detection & \multicolumn{2}{|c|}{13} & \multirow{2}{*}{\multicolumn{2}{|c|}{$\frac{13}{75}$}} & \multicolumn{2}{|c|}{13} \\
\hline Sample volume (liters) & \multicolumn{2}{|c|}{75} & & & & \\
\hline
\end{tabular}

\section{Comments:}

Basidiospores (basidiomycetes): Basidiospores are extremely common outdoors and originate from fungi in gardens, forests, and woodlands. It is rare for the source of basidiospores to be indoors. However, basidiospores may be an indicator of wood decay.

Cladosporium: One of the most commonly found molds outdoors and frequently found growing indoors. Spores from Cladosporium are generally present in outdoor and indoor air, even in relatively clean, mold-growth-free, indoor environments. Levels vary based upon activity levels, weather conditions, dustiness, outside air exchange rates, and other factors.

Penicillium/Aspergillus types: Penicllium and Aspergillus are among the most common molds found growing both indoors and outdoors (even in relatively clean, mold-growth-free, indoor environments). Levels vary based upon activity levels, dustiness, weather conditions, outside air exchange rates, and other factors.

Stachybotrys and other marker types: Certain types of mold, such as Aureobasidium, Chaetomium, Fusarium, Trichoderma, and Ulocladium, are generally found in very low numbers outdoors. Consequently their presence indoors, even in relatively low numbers, is often an indication that these molds are originating from growth indoors. When present, these mold types are often the clearest indicator of a mold problem.

Others: Molds in the "Others" category are generally found outdoors in moderate numbers, and are therefore not considered markers of indoor growth.

A "Version" indicated by -"x" after the Lab ID\# with a value greater than 1 indicates a sample with amended data. The revision number is reflected by the value of "x".

† Backoround debris is an indication of the amounts of non-biological particulate matter present on the slide (dust in the air) and is graded from 1 to 4 with 4 indicating the largest amounts.

The analytical sensitivity is the spores $/ \mathrm{m}^{\wedge} 3$ divided by the raw count, expressed in spores $/ \mathrm{m}^{\wedge} 3$. The limit of detection is the analytical sensitivity (in spores $/ \mathrm{m}^{\wedge} 3$ ) multiplied by the sample volume (in liters) divided by 1000 liters.

$\S$ Total has been rounded to two significant figures to reflect analytical precision

Rer 02 03/11

Aerotech Laboratories, Inc

EMLab ID: 1717739 , Page 2 of 3 
Client: Pure Maintenance

MoldREPORT

Contact: Mr Brandon Adams

EMLab P \& K

Project: Mess Hall 1 Month Post Treatment

nix, AZ 85027

Date of Sampling: 04-25-2017

Date of Receipt: 04-27-2017

Date of Report: 04-28-2017

\section{Laboratory Results}

MoldREPORT: Spore Trap Analysis

\begin{tabular}{|c|c|c|c|c|}
\hline Location: & \multicolumn{2}{|c|}{$\begin{array}{c}4: \\
\text { South East Kitchen A1 }\end{array}$} & \multicolumn{2}{|c|}{$\begin{array}{c}6: \\
\text { Outside } 5 \mathrm{~A} 1\end{array}$} \\
\hline Comments (see below) & \multicolumn{2}{|c|}{ None } & \multicolumn{2}{|c|}{ None } \\
\hline Lab ID-Version: & \multicolumn{2}{|c|}{ 8012806-1 } & \multicolumn{2}{|c|}{$8012807-1$} \\
\hline Analysis Date: & \multicolumn{2}{|c|}{$04 / 28 / 2017$} & \multicolumn{2}{|c|}{$04 / 28 / 2017$} \\
\hline Spore types detected: & raw ct. & per m3 & raw ct. & per $m 3$ \\
\hline Aureobasidium & - & - & - & - \\
\hline Basidiospores & 14 & 750 & 99 & 26,000 \\
\hline Chaetomium & - & - & - & - \\
\hline Cladosporium & - & - & 17 & 910 \\
\hline Fusarium & - & - & - & - \\
\hline Penicillium/Aspergillus types & 10 & 530 & 3 & 160 \\
\hline Stachybotrys & - & - & - & - \\
\hline Trichoderma & - & - & - & - \\
\hline Ulocladium & 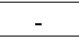 & - & - & - \\
\hline Others & 13 & 690 & 122 & 6,500 \\
\hline § Total: & & 2,000 & & 34.000 \\
\hline \multicolumn{5}{|l|}{ Additional Information: } \\
\hline Hyphal fragments & \multicolumn{2}{|c|}{-} & \multicolumn{2}{|c|}{ - } \\
\hline Skin cells & \multicolumn{2}{|c|}{$80-4,000$} & \multicolumn{2}{|c|}{$13-67$} \\
\hline Pollen & \multicolumn{2}{|c|}{$<13$} & \multicolumn{2}{|c|}{750} \\
\hline Background debris $(1-4) \dagger$ & \multicolumn{2}{|c|}{2} & \multicolumn{2}{|c|}{2} \\
\hline Limit of detection & \multicolumn{2}{|c|}{13} & \multicolumn{2}{|c|}{13} \\
\hline Sample volume (liters) & \multicolumn{2}{|c|}{75} & \multicolumn{2}{|c|}{75} \\
\hline
\end{tabular}

\section{Comments:}

Basidiospores (basidiomycetes): Basidiospores are extremely common outdoors and originate from fungi in gardens, forests, and woodlands. It is rare for the source of basidiospores to be indoors. However, basidiospores may be an indicator of wood decay.

Cladosporium: One of the most commonly found molds outdoors and frequently found growing indoors. Spores from Cladosporium are generally present in outdoor and indoor air, even in relatively clean, mold-growth-free, indoor environments. Levels vary based upon activity levels, weather conditions, dustiness, outside air exchange rates, and other factors.

Penicillium/Aspergillus types: Penicllium and Aspergillus are among the most common molds found growing both indoors and outdoors (even in relatively clean, mold-growth-free, indoor environments). Levels vary based upon activity levels, dustiness, weather conditions, outside air exchange rates, and other factors.

Stachybotrys and other marker types: Certain types of mold, such as Aureobasidium, Chaetomium, Fusarium, Trichoderma, and Ulocladium, are generally found in very low numbers outdoors. Consequently their presence indoors, even in relatively low numbers, is often an indication that these molds are originating from growth indoors. When present, these mold types are often the clearest indicator of a mold problem.

Others: Molds in the "Others" category are generally found outdoors in moderate numbers, and are therefore not considered markers of indoor growth.

$\mp$ A "Version" indicated by -"x" after the Lab ID\# with a value greater than 1 indicates a sample with amended data. The revision number is reflected by the value of " $\mathrm{x}$ ".

† Background debris is an indication of the amounts of non-biological particulate matter present on the slide (dust in the air) and is graded from 1 to 4 with 4 indicating the largest amounts.

The analytical sensitivity is the spores $/ \mathrm{m}^{\wedge} 3$ divided by the raw count, expressed in spores $/ \mathrm{m}^{\wedge} 3$. The limit of detection is the analytical sensitivity (in spores $/ \mathrm{m}^{\wedge} 3$ ) multiplied by the sample volume (in liters) divided by 1000 liters.

$\S$ Total has been rounded to two significant figures to reflect analytical precision.

Rer 02 03/1 
Pure Maintenance

Mr Brandon Adams

596 w $750 \mathrm{~s}$

Suite 300
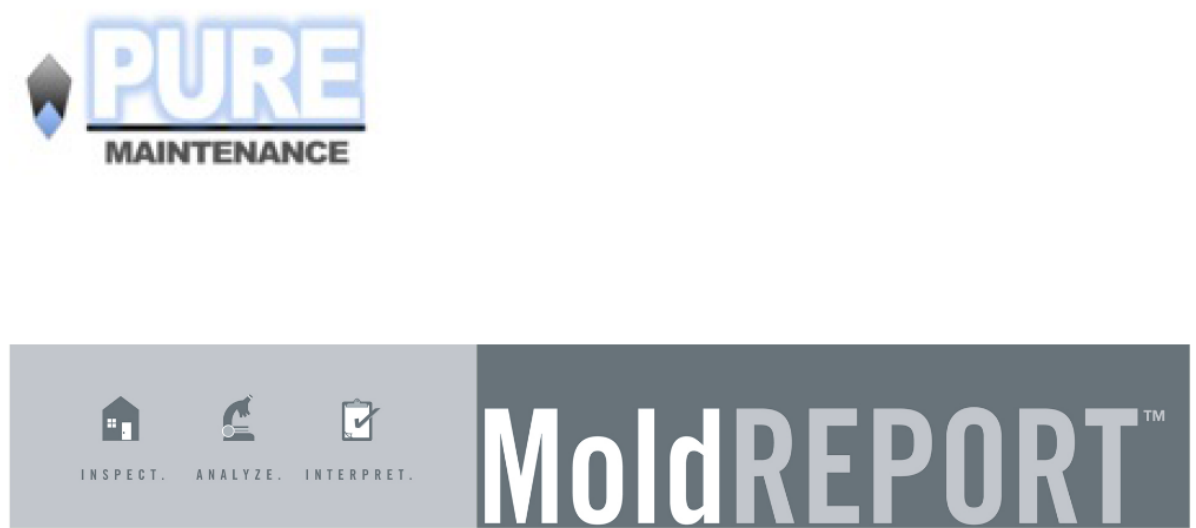

EMLab P \& K

WWW.MoldREPORT.com

info@MoldREPORT.com

Approved by:

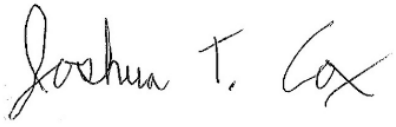

Operations Manager

Joshua Cox
Dates of Analysis:

MoldReport Direct exam: 04-28-2017

Service SOPs: MoldReport Direct exam (EM-MY-S-1039)

AlHA-LAP, LLC accredited service, Lab ID \#102297

All samples were received in acceptable condition unless noted in the Report Comments portion in the body of the report. Due to the nature of the analyses performed, field blank correction of results is not applied. The results relate only to the items tested.

EMLab P\&K ("the Company") shall have no liability to the client or the client's customer with respect to decisions or

recommendations made, actions taken or courses of conduct implemented by either the client or the client's customer as a result of or based upon the Test Results. In no event shall the Company be liable to the client with respect to the Test Results except for the Compary's own willful misconduct or gross negligence nor shall the Company be liable for incidental or consequential damages or lost profits or revenues to the fullest extent such liability may be disclaimed by law, even if the Company has been advised of the possibility of such damages, lost profits or lost revenues. In no event shall the Company's liability with respect to the Test Results exceed the amount paid to the Company by the client therefor. 
Client: Pure Maintenance Contact: Mr Brandon Adams Project: Mess Hall 1 Month Post Treatment Date of Sampling: 04-25-2017 Date of Receipt: 04-27-2017

Date of Report: 04-28-2017
MoldREPORT

EMLab P \& K

1501 West Knudsen Drive, Phoenix, AZ 85027 (800) 651-4802 Fax (623) 780-7695

MoldREPORT: Direct Microscopic Examination

\begin{tabular}{|c|c|c|c|}
\hline Location: & 7: Middle Divider Wall & 8: Kitchen Wall & 9: West Wal \\
\hline Comments (see below): & None & A & None \\
\hline Lab ID-Version $\ddagger$ : & $8012800-1$ & $8012801-1$ & $8012802-1$ \\
\hline \multicolumn{4}{|c|}{$\begin{array}{l}\text { Spore types present (indicative } \\
\text { of mold growth) } \S \text { : }\end{array}$} \\
\hline Aureobasidium & - & - & - \\
\hline Basidiospores & - & - & - \\
\hline Chaetomium & - & - & - \\
\hline Cladosporium & - & - & - \\
\hline Fusarium & - & - & - \\
\hline Lumber mold $\dagger$ & - & - & - \\
\hline Penicillium/Aspergillus types & - & - & - \\
\hline Stachybotrys & - & - & - \\
\hline Trichoderma & - & - & - \\
\hline Ulocladium & - & - & - \\
\hline \multicolumn{4}{|l|}{$\begin{array}{l}\text { Spore types present (not } \\
\text { indicative of mold growth)§: }\end{array}$} \\
\hline All spore types & - & Very few & - \\
\hline \multicolumn{4}{|l|}{ Other particles detected§: } \\
\hline Skin cells & Very few & Very few & Very few \\
\hline Pollen & - & - & - \\
\hline $\begin{array}{l}\text { Background Debris and/or } \\
\text { Description }{ }^{\star *} \text { : }\end{array}$ & Light & Scant & Light \\
\hline
\end{tabular}

Comments: A) A few Penicillium/Aspergillus group spores detected.

Basidiomycetes: Commonly found outdoors. Occasionally may grow indoors, mostly as agents of wood decay.

Cladosporium: One of the most commonly found molds outdoors and frequently found growing indoors.

Penicillium/Aspergillus types: Penicllium and Aspergillus are among the most common molds found growing both indoors and out.

Stachybotrys and other marker types: Certain types of mold, such as Aureobasidium, Chaetomium, Fusarium, Trichoderma, and Ulocladium, are generally found in very low numbers outdoors. Consequently their presence indoors, even in relatively low numbers, is often an indication that these molds are originating from growth indoors. When present, these mold types are often the clearest indicator of a mold problem.

†Lumber mold: Fungi in the Ceratocystis/Ophiostoma group are commonly called "Lumber mold". Lumber mold is present on the wood framing of most homes that are built with lumber. Their presence alone is not in dicative of an indoor water problem.

作 as Scant, Moderate, Heavy, or Very Heavy. Very heavy background debris may obscure visibility for the analyst. Some sample types are not graded for background debris, in which case a brief description of the material is reported.

gra "Version" indicated by -"x" after the Lab ID\# with a value greater than 1 indicates a sample with amended data. The revision number is reflected by the value of "x"

The limit of detection is $<1+$ when mold growth is detected.

§All readers are advised to refer to the document "Understanding Direct Microscopic Examination Results" which is available at our website

WWw.moldreport.com, or by request from the laboratory.

Aerotech Laboratories, Inc 
Pure Maintenance

Mr Brandon Adams

596 w $750 \mathrm{~s}$

Suite 300

Bountiful, UT 84010 USA

(801) 529-2976
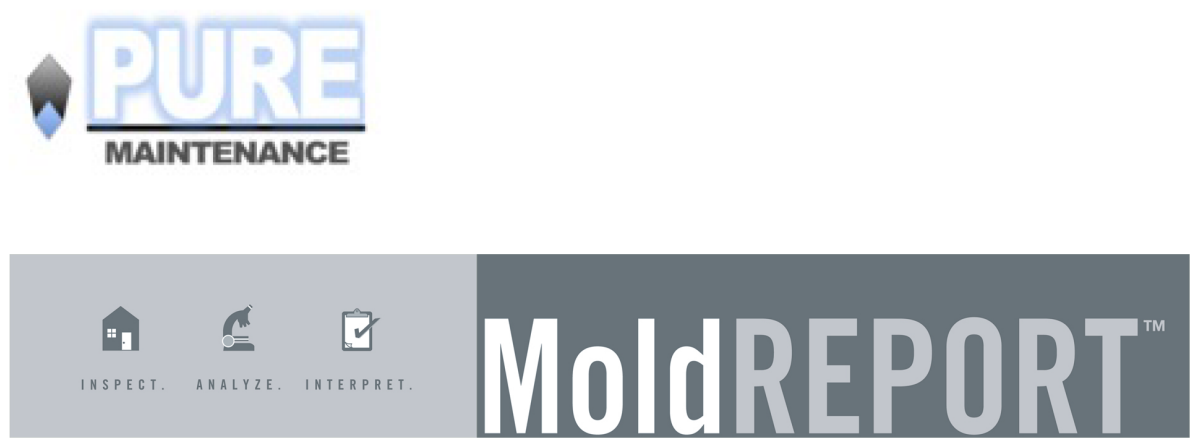

EMLab P \& K

Www.MoldREPORT.com

$$
\text { info@MoldREPORT.com }
$$

Approved by:

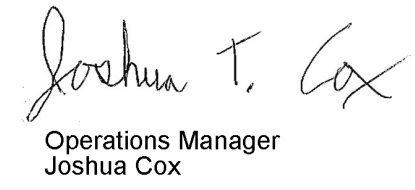

Dates of Analysis:

MoldReport Spore trap: 04-28-2017 and 04-28-2017

Service SOPs: MoldReport Spore trap (EM-MY-S-1038)

AlHA-LAP, LLC accredited service, Lab ID \#102297

All samples were received in acceptable condition unless noted in the Report Comments portion in the body of the report. Due to the nature of the analyses performed, field blank correction of results is not applied. The results relate only to the items tested.

The analytical sensitivity is the spores $/ \mathrm{m}^{\wedge} 3$ divided by the raw count, expressed in spores $/ \mathrm{m}^{\wedge} 3$. The limit of detection is the analytical sensitivity (in spores $/ \mathrm{m}^{\wedge} 3$ ) multiplied by the sample volume (in liters) divided by 1000 liters.

EMLab P\&K ("the Company") shall have no liability to the client or the client's customer with respect to decisions or

recommendations made, actions taken or courses of conduct implemented by either the client or the client's customer as a result of or based upon the Test Results. In no event shall the Company be liable to the client with respect to the Test Results except for the Company's own willful misconduct or gross negligence nor shall the Company be liable for incidental or consequential damages or lost profits or revenues to the fullest extent such liability may be disclaimed by law, even if the Company has been advised of the possibility of such damages, lost profits or lost revenues. In no event shall the Company's liability with respect to the Test Results exceed the amount paid to the Company by the client therefor 
Client: Pure Maintenance

Contact: Mr Brandon Adams

Project: Hammerhead 1 Month Post Treatment

Date of Sampling: 04-25-2017

Date of Receipt: 04-27-2017

Date of Report: 04-28-2017
Mold REPORT

EMLab P \& K

1501 West Knudsen Drive, Phoenix, AZ 85027 (800) 651-4802 Fax (623) 780-7695

MoldREPORT: Spore Trap Analysis

\begin{tabular}{|c|c|c|c|c|}
\hline Location: & \multicolumn{2}{|c|}{$\begin{array}{c}1: \\
\text { Mens Bathroom 11Al }\end{array}$} & \multicolumn{2}{|c|}{$\begin{array}{c}2: \\
\text { Northwest Classroom 10Al }\end{array}$} \\
\hline Comments (see below) & \multicolumn{2}{|c|}{ None } & \multicolumn{2}{|c|}{ None } \\
\hline Lab ID-Versiont: & \multicolumn{2}{|c|}{$8013119-1$} & \multicolumn{2}{|c|}{$8013120-1$} \\
\hline Analysis Date: & \multicolumn{2}{|c|}{$04 / 28 / 2017$} & \multicolumn{2}{|c|}{$04 / 28 / 2017$} \\
\hline Spore types detected: & raw ct. & per $\mathrm{m} 3$ & raw ct. & per $\mathrm{m} 3$ \\
\hline Aureobasidium & - & - & - & - \\
\hline Basidiospores & 2 & 110 & 9 & 480 \\
\hline Chaetomium & - & - & - & - \\
\hline Cladosporium & 1 & 53 & 1 & 53 \\
\hline Fusarium & - & - & - & - \\
\hline Penicillium/Aspergillus types & 16 & 850 & 3 & 160 \\
\hline Stachybotrys & - & - & - & - \\
\hline Trichoderma & - & - & - & - \\
\hline Ulocladium & - & - & - & - \\
\hline Others & 2 & 110 & 9 & 480 \\
\hline$\S$ Total: & & 1,100 & & 1,200 \\
\hline \multicolumn{5}{|l|}{ Additional Information: } \\
\hline Hyphal fragments & \multicolumn{2}{|c|}{-} & \multicolumn{2}{|c|}{ - } \\
\hline Skin cells & \multicolumn{2}{|c|}{$4,000-8,000$} & \multicolumn{2}{|c|}{$13-67$} \\
\hline Pollen & \multicolumn{2}{|c|}{$<13$} & \multicolumn{2}{|c|}{110} \\
\hline Background debris $(1-4) \dagger$ & \multicolumn{2}{|c|}{3} & \multicolumn{2}{|c|}{1} \\
\hline Limit of detection & \multicolumn{2}{|c|}{13} & \multicolumn{2}{|c|}{13} \\
\hline Sample volume (liters) & \multicolumn{2}{|c|}{75} & \multicolumn{2}{|c|}{75} \\
\hline
\end{tabular}

Sample volume (iters)

Comments:

Basidiospores (basidiomycetes): Basidiospores are extremely common outdoors and originate from fungi in gardens, forests, and woodlands. It is rare for the source of basidiospores to be indoors. However, basidiospores may be an indicator of wood decay.

Cladosporium: One of the most commonly found molds outdoors and frequently found growing indoors. Spores from Cladosporium are generally present in outdoor and indoor air, even in relatively clean, mold-growth-free, indoor environments. Levels vary based upon activity levels, weather conditions, dustiness, outside air exchange rates, and other factors.

Penicillium/Aspergillus types: Penicllium and Aspergillus are among the most common molds found growing both indoors and outdoors (even in relatively clean, mold-growth-free, indoor environments). Levels vary based upon activity levels, dustiness, weather conditions, outside air exchange rates, and other factors.

Stachybotrys and other marker types: Certain types of mold, such as Aureobasidium, Chaetomium, Fusarium, Trichoderma, and Ulocladium, are generally found in very low numbers outdoors. Consequently their presence indoors, even in relatively low numbers, is often an indication that these molds are originating from growth indoors. When present, these mold types are often the clearest indicator of a mold problem.

Others: Molds in the "Others" category are generally found outdoors in moderate numbers, and are therefore not considered markers of indoor growth.

$\ddagger$ A "Version" indicated by -"x" after the Lab ID\# with a value greater than 1 indicates a sample with amended data. The revision number is reflected by the value of " $\mathrm{x}$ ".

+ Background debris is an indication of the amounts of non-biological particulate matter present on the slide (dust in the air) and is graded from 1 to 4 with 4 indicating the largest amounts.

The analytical sensitivity is the spores $/ \mathrm{m}^{\wedge} 3$ divided by the raw count, expressed in spores $/ \mathrm{m}^{\wedge} 3$. The limit of detection is the analytical sensitivity (in spores $/ \mathrm{m}^{\wedge} 3$ ) multiplied by the sample volume (in liters) divided by 1000 liters.

$\S$ Total has been rounded to two significant figures to reflect analytical precision.

Rer $0203 / 1$

Aerotech Laboratories, Inc

EMLab ID: 1717764, Page 2 of 3 
Client: Pure Maintenance

Contact: Mr Brandon Adams

Project: Hammerhead 1 Month Post Treatment

Date of Sampling: 04-25-2017

Date of Receipt: 04-27-2017

Date of Report: 04-28-2017
Mold REPORT

EMLab P \& K

1501 West Knudsen Drive, Phoenix, AZ 85027 (800) 651-4802 Fax (623) 780-7695

MoldREPORT: Spore Trap Analysis

\begin{tabular}{|c|c|c|c|c|}
\hline Location: & \multicolumn{2}{|c|}{$\begin{array}{c}3: \\
\text { Basement } 12 \mathrm{Al}\end{array}$} & \multicolumn{2}{|c|}{$\begin{array}{c}5: \\
\text { Outside } 17 \mathrm{~A} 1\end{array}$} \\
\hline Comments (see below) & \multicolumn{2}{|c|}{ None } & \multicolumn{2}{|c|}{ None } \\
\hline Lab ID-Versiont: & \multicolumn{2}{|c|}{ 8013121-1 } & \multicolumn{2}{|c|}{$8013122-1$} \\
\hline Analysis Date: & \multicolumn{2}{|c|}{$04 / 28 / 2017$} & \multicolumn{2}{|c|}{$04 / 28 / 2017$} \\
\hline Spore types detected: & raw ct. & per m3 & raw ct. & per $m 3$ \\
\hline Aureobasidium & - & - & - & - \\
\hline Basidiospores & 29 & 1,500 & 21 & 1,100 \\
\hline Chaetomium & - & 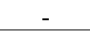 & - & - \\
\hline Cladosporium & 7 & 370 & 3 & 160 \\
\hline Fusarium & - & - & - & - \\
\hline Penicillium/Aspergillus types & 4 & 210 & 4 & 210 \\
\hline Stachybotrys & - & - & - & - \\
\hline Trichoderma & - & - & - & - \\
\hline Ulocladium & 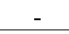 & - & - & - \\
\hline Others & 22 & 1,200 & 124 & 6,600 \\
\hline \$ Total: & & 3,300 & & 8,100 \\
\hline \multicolumn{5}{|l|}{ Additional Information: } \\
\hline Hyphal fragments & \multicolumn{2}{|c|}{-} & \multicolumn{2}{|c|}{-} \\
\hline Skin cells & \multicolumn{2}{|c|}{$13-67$} & \multicolumn{2}{|c|}{$13-67$} \\
\hline Pollen & \multicolumn{2}{|c|}{$<13$} & \multicolumn{2}{|c|}{110} \\
\hline Background debris $(1-4) \dagger$ & \multirow{2}{*}{\multicolumn{2}{|c|}{2}} & \multicolumn{2}{|c|}{2} \\
\hline Limit of detection & & & & \\
\hline Sample volume (liters) & \multicolumn{2}{|c|}{$\frac{15}{75}$} & \multicolumn{2}{|c|}{75} \\
\hline
\end{tabular}

Comments:

Basidiospores (basidiomycetes): Basidiospores are extremely common outdoors and originate from fungi in gardens, forests, and woodlands. It is rare for the source of basidiospores to be indoors. However, basidiospores may be an indicator of wood decay.

Cladosporium: One of the most commonly found molds outdoors and frequently found growing indoors. Spores from Cladosporium are generally present in outdoor and indoor air, even in relatively clean, mold-growth-free, indoor environments. Levels vary based upon activity levels, weather conditions, dustiness, outside air exchange rates, and other factors.

Penicillium/Aspergillus types: Penicllium and Aspergillus are among the most common molds found growing both indoors and outdoors (even in relatively clean, mold-growth-free, indoor environments). Levels vary based upon activity levels, dustiness, weather conditions, outside air exchange rates, and other factors

Stachybotrys and other marker types: Certain types of mold, such as Aureobasidium, Chaetomium, Fusarium, Trichoderma, and Ulocladium, are generally found in very low numbers outdoors. Consequently their presence indoors, even in relatively low numbers, is often an indication that these molds are originating from growth indoors. When present, these mold types are often the clearest indicator of a mold problem.

Others: Molds in the "Others" category are generally found outdoors in moderate numbers, and are therefore not considered markers of indoor growth.

$\ddagger$ A "Version" indicated by -"x" after the Lab ID\# with a value greater than 1 indicates a sample with amended data. The revision number is reflected by the value of " $\mathrm{x}$ "

$t$ Background debris is an indication of the amounts of non-biological particulate matter present on the slide (dust in the air) and is graded from 1 to 4 with 4 indicating the largest amounts.

The analytical sensitivity is the spores $/ \mathrm{m}^{\wedge} 3$ divided by the raw count, expressed in spores $/ \mathrm{m}^{\wedge} 3$. The limit of detection is the analytical sensitivity (in spores $/ \mathrm{m}^{\wedge} 3$ ) multiplied by the sample volume (in liters) divided by 1000 liters.

$\S$ Total has been rounded to two significant figures to reflect analytical precision.

Rer $0203 / 1$

Aerotech Laboratories, Inc

EMLab ID: 1717764, Page 3 of 3 
Pure Maintenance

Mr Brandon Adams

596 w $750 \mathrm{~s}$

Suite $\mathbf{3 0 0}$
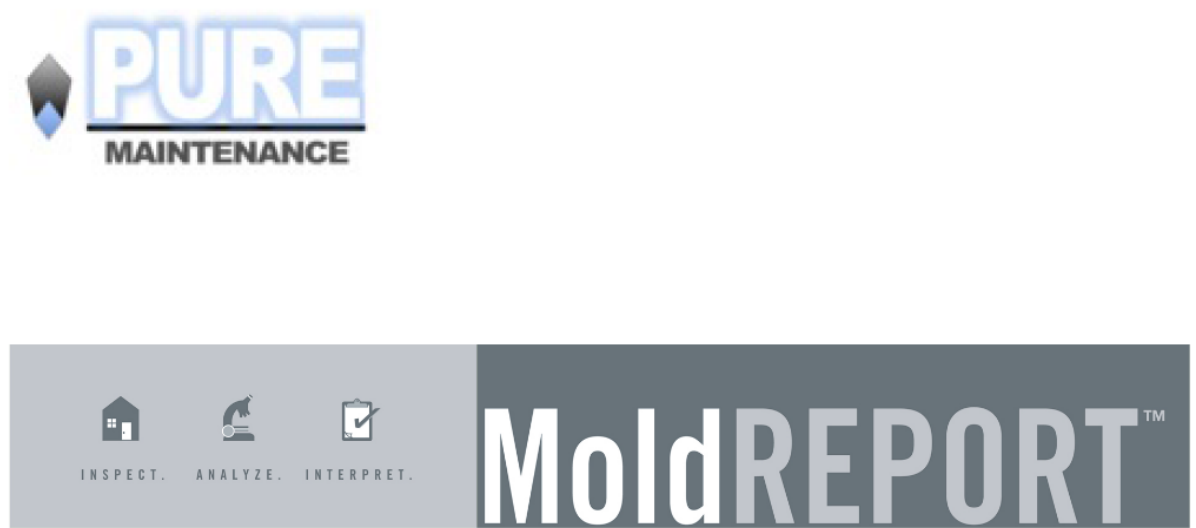

EMLab P \& K

wWW.MoldREPORT.com

info@MoldREPORT.com

Approved by:

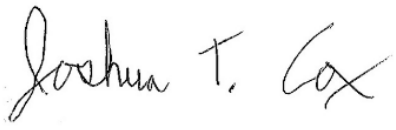

Operations Manager

Joshua Cox
Dates of Analysis:

MoldReport Direct exam: 04-28-2017

Service SOPs: MoldReport Direct exam (EM-MY-S-1039)

AlHA-LAP, LLC accredited service, Lab ID \#102297

All samples were received in acceptable condition unless noted in the Report Comments portion in the body of the report. Due to the nature of the analyses performed, field blank correction of results is not applied. The results relate only to the items tested.

EMLab P\&K ("the Company") shall have no liability to the client or the client's customer with respect to decisions or

recommendations made, actions taken or courses of conduct implemented by either the client or the client's customer as a result of or based upon the Test Results. In no event shall the Company be liable to the client with respect to the Test Results except for the Comparry's own willful misconduct or gross negligence nor shall the Company be liable for incidental or consequential damages or lost profits or revenues to the fullest extent such liability may be disclaimed by law, even if the Company has been advised of the possibility of such damages, lost profits or lost revenues. In no event shall the Company's liability with respect to the Test Results exceed the amount paid to the Company by the client therefor. 
Client: Pure Maintenance Contact: Mr Brandon Adams Project: Hammerhead 1 Month Post Treatment Date of Sampling: 04-25-2017

Date of Receipt: 04-27-2017

Date of Report: 04-28-2017
MoldREPORT

EMLab P \& K

1501 West Knudsen Drive, Phoenix, AZ 85027 (800) 651-4802 Fax (623) 780-7695

MoldREPORT: Direct Microscopic Examination

\begin{tabular}{|c|c|c|c|}
\hline Location: & 6: Bathroom Southwall & 7: Basement Southwall & $\begin{array}{l}\text { 8: Northwest } \\
\text { Classroom }\end{array}$ \\
\hline Comments (see below): & None & None & None \\
\hline Lab ID-Version $\ddagger$ : & $8013116-1$ & $8013117-1$ & $8013118-1$ \\
\hline \multicolumn{4}{|c|}{$\begin{array}{l}\text { Spore types present (indicative } \\
\text { of mold growth) } \$ \text { : }\end{array}$} \\
\hline Aureobasidium & - & - & - \\
\hline Basidiospores & - & - & - \\
\hline Chaetomium & - & - & - \\
\hline Cladosporium & - & - & - \\
\hline Fusarium & - & - & - \\
\hline Lumber mold $†$ & - & - & - \\
\hline Penicillium/Aspergillus types & - & - & - \\
\hline Stachybotrys & - & - & - \\
\hline Trichoderma & - & - & - \\
\hline Ulocladium & - & - & - \\
\hline \multicolumn{4}{|l|}{$\begin{array}{l}\text { Spore types present (not } \\
\text { indicative of mold growth) } \$ \text { : }\end{array}$} \\
\hline All spore types & - & Very few & Very few \\
\hline \multicolumn{4}{|l|}{ Other particles detected§: } \\
\hline Skin cells & Very few & Very few & Very few \\
\hline Pollen & - & - & - \\
\hline $\begin{array}{l}\text { Background Debris and/or } \\
\text { Description }{ }^{\star *} \text { : }\end{array}$ & Scant & Light & Scant \\
\hline
\end{tabular}

Comments: None

Basidiomycetes: Commonly found outdoors. Occasionally may grow indoors, mostly as agents of wood decay.

Cladosporium: One of the most commonly found molds outdoors and frequently found growing indoors.

Penicillium/Aspergillus types: Penicllium and Aspergillus are among the most common molds found growing both indoors and out.

Stachybotrys and other marker types: Certain types of mold, such as Aureobasidium, Chaetomium, Fusarium, Trichoderma, and Ulocladium, are generally found in very low numbers outdoors. Consequently their presence indoors, even in relatively low numbers, is often an indication that these molds are originating from growth indoors. When present, these mold types are often the clearest indicator of a mold problem.

†Lumber mold: Fungi in the Ceratocystis/Ophiostoma group are commonly called "Lumber mold". Lumber mold is present on the wood framing of most homes that are built with lumber. Their presence alone is not indicative of an indoor water problem.

作 as Scant, Moderate, Heavy, or Very Heavy. Very heavy background debris may obscure visibility for the analyst. Some sample types are not graded for background debris, in which case a brief description of the material is reported.

$¥$ A "Version" indicated by -" $x$ " after the Lab ID\# with a value greater than 1 indicates a sample with amended data. The revision number is

reflected by the value of " $x "$ ".
The limit of detection is $<1+$ when mold growth is detected.

$\S$ All readers are advised to refer to the document "Understanding Direct Microscopic Examination Results" which is available at our website

www. moldreport.com, or by request from the laboratory.

Aerotech Laboratories, Inc 
Pure Maintenance

Mr Brandon Adams

596 w $750 \mathrm{~s}$

Suite 300

Bountiful, UT 84010 USA

(801) 529-2976
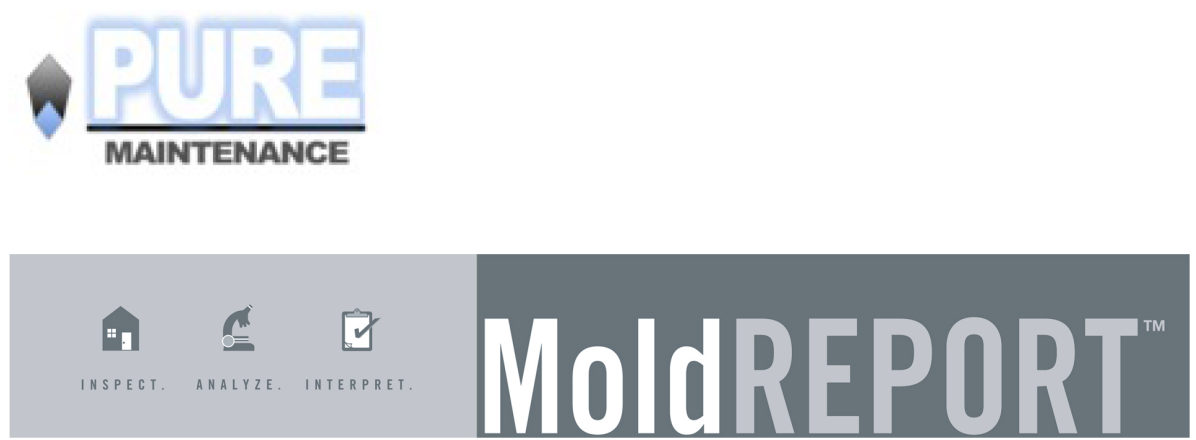

EMLab P \& K

WwW.MoldREPORT.com

info@MoldREP0RT.com

Approved by:

Dates of Analysis:

Approved by:

MoldReport Spore trap: 06-28-2017

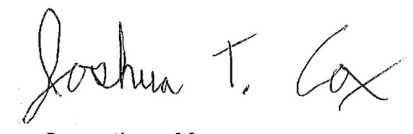

Operations Manager

Joshua Cox

Service SOPs: MoldReport Spore trap (EM-MY-S-1038)

AlHA-LAP, LLC accredited service, Lab ID \#102297

All samples were received in acceptable condition unless noted in the Report Comments portion in the body of the report. Due to the nature of the analyses performed, field blank correction of results is not applied. The results relate only to the items tested.

The analytical sensitivity is the spores $/ \mathrm{m}^{\wedge} 3$ divided by the raw count, expressed in spores $/ \mathrm{m}^{\wedge} 3$. The limit of detection is the analytical sensitivity (in spores $/ \mathrm{m}^{\wedge} 3$ ) multiplied by the sample volume (in liters) divided by 1000 liters.

EMLab P\&K ("the Company") shall have no liability to the client or the client's customer with respect to decisions or

recommendations made, actions taken or courses of conduct implemented by either the client or the client's customer as a result of or based upon the Test Results. In no event shall the Company be liable to the client with respect to the Test Results except for the Company's own willful misconduct or gross negligence nor shall the Company be liable for incidental or consequential damages or lost profits or revenues to the fullest extent such liability may be disclaimed by law, even if the Company has been advised of the possibility of such damages, lost profits or lost revenues. In no event shall the Company's liability with respect to the Test Results exceed the amount paid to the Company by the client therefor. 
Client: Pure Maintenance

MoldREPORT

Contact: Mr Brandon Adam

EMLab P \& K

Project: Hammer Head AT

1501 West Knudsen Drive, Phoenix, AZ 85027

Date of Receipt: $06-27-2017$

(800) 651-4802 Fax (623) 780-7695

Date of Report: 06-28-2017

\section{Laboratory Results}

MoldREPORT: Spore Trap Analysis

\begin{tabular}{|c|c|c|c|c|}
\hline Location: & \multicolumn{2}{|c|}{$\begin{array}{c}\text { 1: } \\
\text { Outside }\end{array}$} & \multicolumn{2}{|c|}{$\begin{array}{c}2: \\
\text { Basement }\end{array}$} \\
\hline Comments (see below) & \multicolumn{2}{|c|}{ None } & \multicolumn{2}{|c|}{$\mathrm{A}$} \\
\hline Lab ID-Versiont: & \multicolumn{2}{|c|}{$8171009-1$} & \multicolumn{2}{|c|}{$8171010-1$} \\
\hline Analysis Date: & \multicolumn{2}{|c|}{$06 / 28 / 2017$} & \multicolumn{2}{|c|}{$06 / 28 / 2017$} \\
\hline Spore types detected: & raw et. & per $\mathrm{m} 3$ & raw ct. & per $\mathrm{m} 3$ \\
\hline Aureobasidium & - & - & - & - \\
\hline Basidiospores & 42 & 5,600 & 4 & 210 \\
\hline Chaetomium & - & - & - & - \\
\hline Cladosporium & 8 & 430 & 50 & 870 \\
\hline Fusarium & - & - & - & - \\
\hline Penicillium/Aspergillus types & 2 & 110 & 1 & 53 \\
\hline Stachybotrys & 1 & 13 & - & - \\
\hline Trichoderma & - & - & - & - \\
\hline Ulocladium & - & - & - & - \\
\hline Others & 61 & 8,100 & 2 & 110 \\
\hline$\S$ Total: & & 14,000 & & 1,200 \\
\hline \multicolumn{5}{|l|}{ Additional Information: } \\
\hline Hyphal fragments & \multicolumn{2}{|c|}{-} & \multicolumn{2}{|c|}{ - } \\
\hline Skin cells & \multicolumn{2}{|c|}{$13-67$} & \multicolumn{2}{|c|}{$13-67$} \\
\hline Pollen & \multicolumn{2}{|c|}{$<13$} & \multicolumn{2}{|c|}{$<13$} \\
\hline Background debris $(1-4) \dagger$ & \multicolumn{2}{|c|}{1} & \multicolumn{2}{|c|}{1} \\
\hline Limit of detection & \multicolumn{2}{|c|}{13} & \multicolumn{2}{|c|}{13} \\
\hline Sample volume (liters) & \multicolumn{2}{|c|}{75} & \multicolumn{2}{|c|}{75} \\
\hline
\end{tabular}

Comments: A) 45 of the raw count Cladosporium spores were present as a single clump.

Basidiospores (basidiomycetes): Basidiospores are extremely common outdoors and originate from fungi in gardens, forests, and woodlands. It is rare for the source of basidiospores to be indoors. However, basidiospores may be an indicator of wood decay.

Cladosporium: One of the most commonly found molds outdoors and frequently found growing indoors. Spores from Cladosporium are generally present in outdoor and indoor air, even in relatively clean, mold-growth-free, indoor environments. Levels vary based upon activity levels, weather conditions, dustiness, outside air exchange rates, and other factors.

Penicillium/Aspergillus types: Penicllium and Aspergillus are among the most common molds found growing both indoors and outdoors (even in relatively clean, mold-growth-free, indoor environments). Levels vary based upon activity levels, dustiness, weather conditions, outside air exchange rates, and other factors.

Stachybotrys and other marker types: Certain types of mold, such as Aureobasidium, Chaetomium, Fusarium, Trichoderma, and Ulocladium, are generally found in very low numbers outdoors. Consequently their presence indoors, even in relatively low numbers, is often an indication that these molds are originating from growth indoors. When present, these mold types are often the clearest indicator of a mold problem.

Others: Molds in the "Others" category are generally found outdoors in moderate numbers, and are therefore not considered markers of indoor growth.

† A "Version" indicated by -" $\mathrm{x"}$ after the Lab ID\# with a value greater than 1 indicates a sample with amended data. The revision number is reflected by the value of " $\mathrm{x}$ ".

round debris is an indication of the amounts of non-biological particulate matter present on the slide (dust in the air) and is graded from 1 to 4 with 4 indicating the largest amounts.

The analytical sensitivity is the spores $/ \mathrm{m}^{\wedge} 3$ divided by the raw count, expressed in spores $/ \mathrm{m}^{\wedge} 3$. The limit of detection is the analytical sensitivity (in spores $/ \mathrm{m}^{\wedge} 3$ ) multiplied by the sample volume (in liters) divided by 1000 liters.

$\S$ Total has been rounded to two significant figures to reflect analytical precision.

Rer $0203 / 1$

Aerotech Laboratories, Inc

EMLab ID: 1749926, Page 2 of 3 
Client: Pure Maintenance

MoldREPORT

Contact: Mr Brandon Adam

EMLab P \& K

Project: Hammer Head AT

1501 West Knudsen Drive, Phoenix, AZ 85027

Date of Receipt: 06-27-2017

(800) 651-4802 Fax (623) 780-7695

Date of Report: 06-28-2017

\section{Laboratory Results}

MoldREPORT: Spore Trap Analysis

\begin{tabular}{|c|c|c|c|c|}
\hline Location: & \multicolumn{2}{|c|}{$\begin{array}{c}\text { 3: } \\
\text { N.W. Classroom }\end{array}$} & \multicolumn{2}{|c|}{$\begin{array}{c}4: \\
\text { Mens Bathroom }\end{array}$} \\
\hline Comments (see below) & \multicolumn{2}{|c|}{ None } & \multicolumn{2}{|c|}{ None } \\
\hline Lab ID-Versiont: & \multicolumn{2}{|c|}{$8171011-1$} & \multicolumn{2}{|c|}{$8171012-1$} \\
\hline Analysis Date: & \multicolumn{2}{|c|}{$06 / 28 / 2017$} & \multicolumn{2}{|c|}{$06 / 28 / 2017$} \\
\hline Spore types detected: & raw et. & per $\mathrm{m} 3$ & raw ct. & per $\operatorname{mn} 3$ \\
\hline Aureobasidium & - & - & - & - \\
\hline Basidiospores & - & - & - & - \\
\hline Chaetomium & - & - & - & - \\
\hline Cladosporium & 3 & 160 & 1 & 53 \\
\hline Fusarium & - & - & - & - \\
\hline Penicillium/Aspergillus types & 3 & 160 & 5 & 270 \\
\hline Stachybotrys & - & - & - & - \\
\hline Trichoderma & - & - & - & - \\
\hline Ulocladium & - & - & - & - \\
\hline Others & 2 & 110 & 3 & 160 \\
\hline$\S$ Total: & & 430 & & 480 \\
\hline \multicolumn{5}{|l|}{ Additional Information: } \\
\hline Hyphal fragments & \multicolumn{2}{|c|}{-} & \multicolumn{2}{|c|}{-} \\
\hline Skin cells & \multicolumn{2}{|c|}{$13-67$} & \multicolumn{2}{|c|}{$13-67$} \\
\hline Pollen & \multicolumn{2}{|c|}{$<13$} & \multicolumn{2}{|c|}{$<13$} \\
\hline Background debris $(1-4) \dagger$ & \multicolumn{2}{|c|}{1} & \multicolumn{2}{|c|}{2} \\
\hline Limit of detection & \multicolumn{2}{|c|}{13} & \multicolumn{2}{|c|}{13} \\
\hline Sample volume (liters) & \multicolumn{2}{|c|}{75} & \multicolumn{2}{|c|}{75} \\
\hline
\end{tabular}

\section{Comments:}

Basidiospores (basidiomycetes): Basidiospores are extremely common outdoors and originate from fungi in gardens, forests, and woodlands. It is rare for the source of basidiospores to be indoors. However, basidiospores may be an indicator of wood decay.

Cladosporium: One of the most commonly found molds outdoors and frequently found growing indoors. Spores from Cladosporium are generally present in outdoor and indoor air, even in relatively clean, mold-growth-free, indoor environments. Levels vary based upon activity levels, weather conditions, dustiness, outside air exchange rates, and other factors.

Penicillium/Aspergillus types: Penicllium and Aspergillus are among the most common molds found growing both indoors and outdoors (even in relatively clean, mold-growth-free, indoor environments). Levels vary based upon activity levels, dustiness, weather conditions, outside air exchange rates, and other factors.

Stachybotrys and other marker types: Certain types of mold, such as Aureobasidium, Chaetomium, Fusarium, Trichoderma, and Ulocladium, are generally found in very low numbers outdoors. Consequently their presence indoors, even in relatively low numbers, is often an indication that these molds are originating from growth indoors. When present, these mold types are often the clearest indicator of a mold problem.

Others: Molds in the "Others" category are generally found outdoors in moderate numbers, and are therefore not considered markers of indoor growth.

† A "Version" indicated by -"x" after the Lab ID\# with a value greater than 1 indicates a sample with amended data. The revision number is reflected by the value of " $\mathrm{x}$ ".

+ Background debris is an indication of the amounts of non-biological particulate matter present on the slide (dust in the air) and is graded from 1 to 4 with 4 indicating the largest amounts.

The analytical sensitivity is the spores $/ \mathrm{m}^{\wedge} 3$ divided by the raw count, expressed in spores $/ \mathrm{m}^{\wedge} 3$. The limit of detection is the analytical sensitivity (in spores $/ \mathrm{m}^{\wedge} 3$ ) multiplied by the sample volume (in liters) divided by 1000 liters.

$\S$ Total has been rounded to two significant figures to reflect analytical precision.

Rer $0203 / 1$

Aerotech Laboratories, Inc

EMLab ID: 1749926 , Page 3 of 3 
Pure Maintenance

Mr Brandon Adams

596 w $750 \mathrm{~s}$

Suite 300
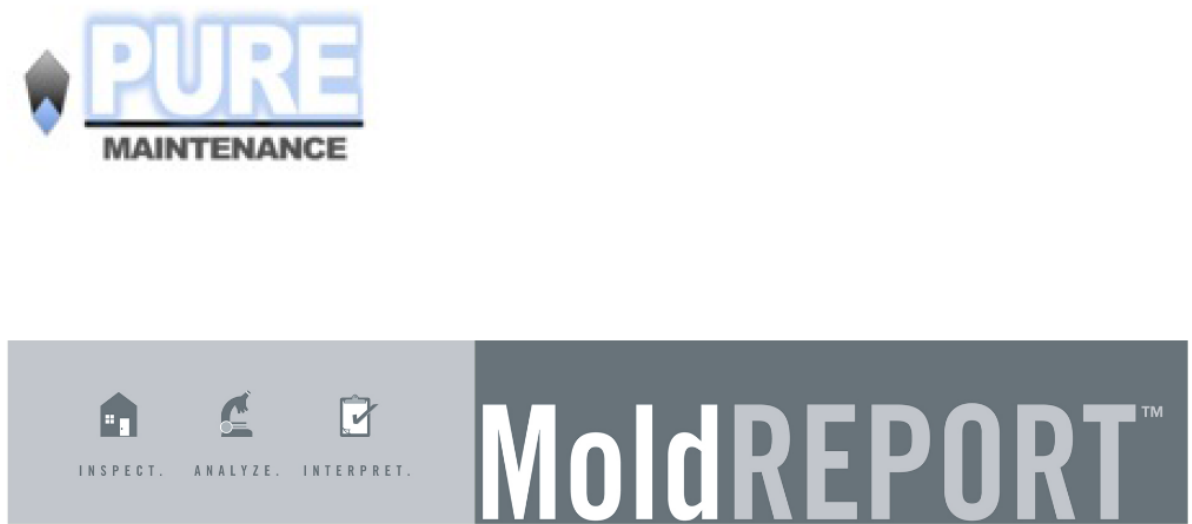

EMLab P \& K

WWW.MoldREPORT.com

info@MoldREPORT.com

Approved by:

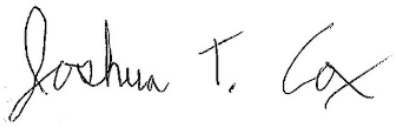

Operations Manager

Joshua Cox
Dates of Analysis:

MoldReport Direct exam: 06-28-2017

Service SOPs: MoldReport Direct exam (EM-MY-S-1039)

AlHA-LAP, LLC accredited service, Lab ID \#102297

All samples were received in acceptable condition unless noted in the Report Comments portion in the body of the report. Due to the nature of the analyses performed, field blank correction of results is not applied. The results relate only to the items tested.

EMLab P\&K ("the Company") shall have no liability to the clicnt or the client's customer with respect to decisions or

recommendations made, actions taken or courses of conduct implemented by either the client or the client's customer as a result of or based upon the Test Results. In no event shall the Company be liable to the client with respect to the Test Results except for the Compary's own willful misconduct or gross negligence nor shall the Company be liable for incidental or consequential damages or lost profits or revenues to the fullest extent such liability may be disclaimed by law, even if the Company has been advised of the possibility of such damages, lost profits or lost revenues. In no event shall the Company's liability with respect to the Test Results exceed the amount paid to the Company by the client therefor. 
Client: Pure Maintenance Contact. Mr Brandon Adam Project: Hammer Head AT

Date of Receipt: 06-27-2017

Date of Report: 06-28-2017
MoldREPORT

EMLab P \& K

1501 West Knudsen Drive, Phoenix, AZ 85027 (800) 651-4802 Fax (623) 780-7695

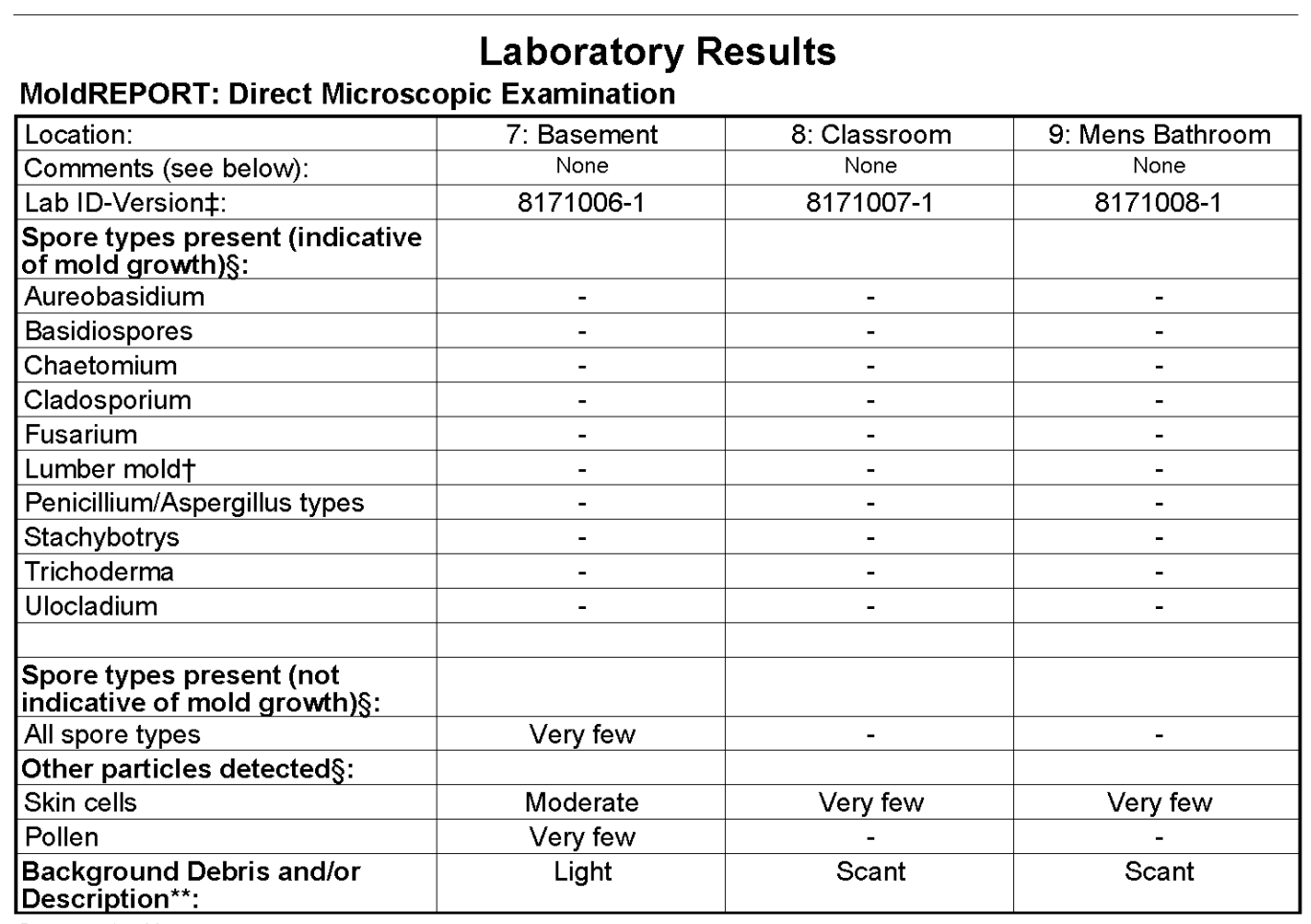

Comments: None

Basidiomycetes: Commonly found outdoors. Occasionally may grow indoors, mostly as agents of wood decay.

Cladosporium: One of the most commonly found molds outdoors and frequently found growing indoors.

Penicillium/Aspergillus types: Penicllium and Aspergillus are among the most common molds found growing both indoors and out.

Stachybotrys and other marker types: Certain types of mold, such as Aureobasidium, Chaetomium, Fusarium, Trichoderma, and Ulocladium, are generally found in very low numbers outdoors. Consequently their presence indoors, even in relatively low
numbers, is often an indication that these molds are originating from growth indoors. When present, these mold types are often the numbers, is often an indication that thes
clearest indicator of a mold problem.

†Lumber mold: Fungi in the Ceratocystis/Ophiostoma group are commonly called "Lumber mold". Lumber mold is present on the wood framing of most homes that are built with lumber. Their presence alone is not in dicative of an indoor water problem.

material is graded and described as Scant, Moderate, Heavy, or Very Heavy. Very heavy background debris may obscure visibility for the analyst. Some sample types are not graded for background debris, in which case a brief description of the material is reported.

gra "Version" indicated by " "x" after the Lab ID with a value greater than 1 indicates a sample with amended data. The revision number is reflected by the value of "x".

The limit of detection is $<1+$ when mold growth is detected.

§All readers are advised to refer to the document "Understanding Direct Microscopic Examination Results" which is available at our website

www.moldreport.com, or by request from the laboratory.

Aerotech Laboratories, Inc 
Pure Maintenance

Mr Brandon Adams

596 w $750 \mathrm{~s}$

Suite 300

Bountiful, UT 84010 USA

(801) 529-2976
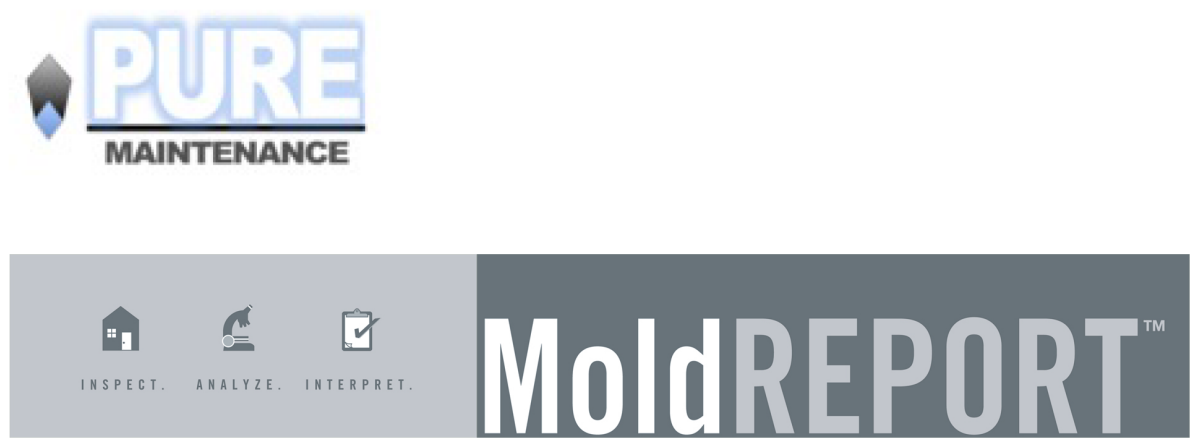

EMLab P \& K

www.MoldREPORT.com

$$
\text { info@MoldREPORT.com }
$$

Approved by:

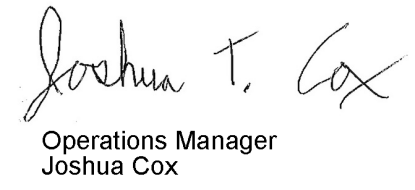

Dates of Analysis:

MoldReport Spore trap: 06-28-2017

Service SOPs: MoldReport Spore trap (EM-MY-S-1038)

AlHA-LAP, LLC accredited service, Lab ID \#102297

All samples were received in acceptable condition unless noted in the Report Comments portion in the body of the report. Due to the nature of the analyses performed, field blank correction of results is not applied. The results relate only to the items tested.

The analytical sensitivity is the spores $/ \mathrm{m}^{\wedge} 3$ divided by the raw count, expressed in spores $/ \mathrm{m}^{\wedge} 3$. The limit of detection is the analytical sensitivity (in spores/ $\mathrm{m}^{\wedge} 3$ ) multiplied by the sample volume (in liters) divided by 1000 liters.

EMLab P\&K ("the Company") shall have no liability to the client or the client's customer with respect to decisions or recommendations made, actions taken or courses of conduct implemented by either the client or the client's customer as a result of or based upon the Test Results. In no event shall the Company be liable to the client with respect to the Test Results except for the Company's own willful misconduct or gross negligence nor shall the Company be liable for incidental or consequential damages or lost profits or revenues to the fullest extent such liability may be disclaimed by law, even if the Company has been advised of the possibility of such damages, lost profits or lost revenues. In no event shall the Company's liability with respect to the Test Results exceed the amount paid to the Company by the client therefor. 
Client: Pure Maintenance

MoldREPORT

Contact: Mr Brandon Adam

EMLab P \& K
Phoenix, AZ 85027

Project: Mess Hall AT
Date of Sampling: 06-22-2017

Date of Receipt: $06-27-2017$

Date of Report: 06-28-2017

\section{Laboratory Results}

MoldREPORT: Spore Trap Analysis

\begin{tabular}{|c|c|c|c|c|c|c|}
\hline Location: & \multicolumn{2}{|c|}{$\begin{array}{c}1: \\
\text { Outside }\end{array}$} & \multicolumn{2}{|c|}{$\begin{array}{c}2: \\
\text { N.W. Corner }\end{array}$} & \multicolumn{2}{|c|}{$\begin{array}{c}3: \\
\text { S.W. Office }\end{array}$} \\
\hline Comments (see below) & \multicolumn{2}{|c|}{ None } & \multicolumn{2}{|c|}{ None } & \multicolumn{2}{|c|}{ None } \\
\hline Lab ID-Versiont: & \multicolumn{2}{|c|}{$8171189-1$} & \multicolumn{2}{|c|}{$8171190-1$} & \multicolumn{2}{|c|}{$8171191-1$} \\
\hline Analysis Date: & \multicolumn{2}{|c|}{$06 / 28 / 2017$} & \multicolumn{2}{|c|}{$06 / 28 / 2017$} & \multicolumn{2}{|c|}{$06 / 28 / 2017$} \\
\hline Spore types detected: & raw ct. & per $\mathrm{m} 3$ & raw ct. & per m3 & raw ct. & per m3 \\
\hline Aureobasidium & - & - & - & - & - & - \\
\hline Basidiospores & 97 & 5,200 & 2 & 27 & 7 & 370 \\
\hline Chaetomium & - & - & - & - & 1 & 13 \\
\hline Cladosporium & 10 & 530 & - & - & 24 & 1,300 \\
\hline Fusarium & - & - & - & - & - & - \\
\hline Penicillium/Aspergillus types & 2 & 110 & 9 & 120 & 5 & 270 \\
\hline Stachybotrys & - & - & - & - & - & - \\
\hline Trichoderma & - & - & - & - & - & - \\
\hline Ulocladium & - & - & - & - & - & - \\
\hline Others & 60 & 3,200 & 2 & 27 & 13 & 690 \\
\hline \& Total: & & 9,000 & & 170 & & 2.600 \\
\hline \multicolumn{7}{|l|}{ Additional Information: } \\
\hline Hyphal fragments & \multicolumn{2}{|c|}{-} & \multicolumn{2}{|r|}{ 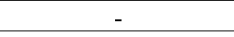 } & \multicolumn{2}{|c|}{ - } \\
\hline Skin cells & \multicolumn{2}{|c|}{$13-67$} & \multicolumn{2}{|c|}{$13-67$} & \multicolumn{2}{|c|}{$13-67$} \\
\hline Pollen & \multicolumn{2}{|c|}{$<13$} & \multirow{2}{*}{\multicolumn{2}{|c|}{$<13$}} & \multicolumn{2}{|c|}{$<13$} \\
\hline Background debris $(1-4) \dagger$ & \multirow{2}{*}{\multicolumn{2}{|c|}{3}} & & & \multirow{2}{*}{\multicolumn{2}{|c|}{$\frac{2}{13}$}} \\
\hline Limit of detection & & & 1 & 13 & & \\
\hline Sample volume (liters) & \multicolumn{2}{|c|}{75} & \multicolumn{2}{|r|}{$\frac{13}{75}$} & \multicolumn{2}{|c|}{75} \\
\hline
\end{tabular}

\section{Comments:}

Basidiospores (basidiomycetes): Basidiospores are extremely common outdoors and originate from fungi in gardens, forests, and woodlands. It is rare for the source of basidiospores to be indoors. However, basidiospores may be an indicator of wood decay.

Cladosporium: One of the most commonly found molds outdoors and frequently found growing indoors. Spores from Cladosporium are generally present in outdoor and indoor air, even in relatively clean, mold-growth-free, indoor environments. Levels vary based upon activity levels, weather conditions, dustiness, outside air exchange rates, and other factors.

Penicillium/Aspergillus types: Penicllium and Aspergillus are among the most common molds found growing both indoors and outdoors (even in relatively clean, mold-growth-free, indoor environments). Levels vary based upon activity levels, dustiness, weather conditions, outside air exchange rates, and other factors.

Stachybotrys and other marker types: Certain types of mold, such as Aureobasidium, Chaetomium, Fusarium, Trichoderma, and Ulocladium, are generally found in very low numbers outdoors. Consequently their presence indoors, even in relatively low numbers, is often an indication that these molds are originating from growth indoors. When present, these mold types are often the clearest indicator of a mold problem.

Others: Molds in the "Others" category are generally found outdoors in moderate numbers, and are therefore not considered markers of indoor growth.

† A "Version" indicated by -"x" after the Lab ID\# with a value greater than 1 indicates a sample with amended data. The revision number is reflected by the value of " $\mathrm{x}$ ".

† Background debris is an indication of the amounts of non-biological particulate matter present on the slide (dust in the air) and is graded from 1 to 4 with 4 indicating the largest amounts.

The analytical sensitivity is the spores $/ \mathrm{m}^{\wedge} 3$ divided by the raw count, expressed in spores $/ \mathrm{m}^{\wedge} 3$. The limit of detection is the analytical sensitivity (in spores $/ \mathrm{m}^{\wedge} 3$ ) multiplied by the sample volume (in liters) divided by 1000 liters.

$\S$ Total has been rounded to two significant figures to reflect analytical precision.

Rer $0203 / 1$

Aerotech Laboratories, Inc

EMLab ID: 1749950 , Page 2 of 3 
Client: Pure Maintenance

MoldREPORT

Contact: Mr Brandon Adam

EMLab P \& K
Phoenix, AZ 85027

Project: Mess Hall AT
Date of Sampling: 06-22-2017

Date of Receipt: 06-27-2017

Date of Report: 06-28-2017

MoldREPORT: Spore Trap Analysis

\begin{tabular}{|c|c|c|c|c|}
\hline Location: & \multicolumn{2}{|c|}{$\begin{array}{c}4: \\
\text { Middle West }\end{array}$} & \multicolumn{2}{|c|}{$\begin{array}{ll}5: \\
\text { S.E. Corner }\end{array}$} \\
\hline Comments (see below) & \multicolumn{2}{|c|}{ None } & \multicolumn{2}{|c|}{ None } \\
\hline Lab ID-Versiont: & \multicolumn{2}{|c|}{$8171192-1$} & \multicolumn{2}{|c|}{ 8171193-1 } \\
\hline Analysis Date: & \multicolumn{2}{|c|}{$06 / 28 / 2017$} & \multicolumn{2}{|c|}{$06 / 28 / 2017$} \\
\hline Spore types detected: & raw ct. & per m3 & raw ct. & per $\mathrm{m} 3$ \\
\hline Aureobasidium & - & - & - & - \\
\hline Basidiospores & 2 & 110 & 8 & 430 \\
\hline Chaetomium & - & - & - & - \\
\hline Cladosporium & 1 & 53 & 23 & 1,200 \\
\hline Fusarium & - & - & - & - \\
\hline Penicillium/Aspergillus types & 1 & 53 & 5 & 270 \\
\hline Stachybotrys & - & - & - & - \\
\hline Trichoderma & - & - & - & - \\
\hline Ulocladium & - & - & - & - \\
\hline Others & 5 & 270 & 16 & 850 \\
\hline \& Total: & & 480 & & 2,800 \\
\hline \multicolumn{5}{|l|}{ Additional Information: } \\
\hline Hyphal fragments & \multicolumn{2}{|c|}{ - } & \multicolumn{2}{|c|}{-} \\
\hline Skin cells & \multicolumn{2}{|c|}{$13-67$} & \multicolumn{2}{|c|}{$13-67$} \\
\hline Pollen & \multicolumn{2}{|c|}{$<13$} & \multicolumn{2}{|c|}{$<13$} \\
\hline Background debris $(1-4) \dagger$ & \multirow{2}{*}{\multicolumn{2}{|c|}{$\frac{1}{13}$}} & \multicolumn{2}{|c|}{1} \\
\hline Limit of detection & & & \multicolumn{2}{|c|}{13} \\
\hline Sample volume (liters) & \multicolumn{2}{|c|}{75} & & \\
\hline
\end{tabular}

lume (liters)

Comments:

Basidiospores (basidiomycetes): Basidiospores are extremely common outdoors and originate from fungi in gardens, forests, and woodlands. It is rare for the source of basidiospores to be indoors. However, basidiospores may be an indicator of wood decay.

Cladosporium: One of the most commonly found molds outdoors and frequently found growing indoors. Spores from Cladosporium are generally present in outdoor and indoor air, even in relatively clean, mold-growth-free, indoor environments. Levels vary based upon activity levels, weather conditions, dustiness, outside air exchange rates, and other factors.

Penicillium/Aspergillus types: Penicllium and Aspergillus are among the most common molds found growing both indoors and outdoors (even in relatively clean, mold-growth-free, indoor environments). Levels vary based upon activity levels, dustiness, weather conditions, outside air exchange rates, and other factors.

Stachybotrys and other marker types: Certain types of mold, such as Aureobasidium, Chaetomium, Fusarium, Trichoderma, and Ulocladium, are generally found in very low numbers outdoors. Consequently their presence indoors, even in relatively low numbers, is often an indication that these molds are originating from growth indoors. When present, these mold types are often the clearest indicator of a mold problem.

Others: Molds in the "Others" category are generally found outdoors in moderate numbers, and are therefore not considered markers of indoor growth.

† A "Version" indicated by -"x" after the Lab ID\# with a value greater than 1 indicates a sample with amended data. The revision number is reflected by the value of " $\mathrm{x}$ ".

+ Background debris is an indication of the amounts of non-biological particulate matter present on the slide (dust in the air) and is graded from 1 to 4 with 4 indicating the largest amounts.

The analytical sensitivity is the spores $/ \mathrm{m}^{\wedge} 3$ divided by the raw count, expressed in spores $/ \mathrm{m}^{\wedge} 3$. The limit of detection is the analytical sensitivity (in spores $/ \mathrm{m}^{\wedge} 3$ ) multiplied by the sample volume (in liters) divided by 1000 liters.

$\S$ Total has been rounded to two significant figures to reflect analytical precision.

Rer $0203 / 1$

Aerotech Laboratories, Inc

EMLab ID: 1749950 , Page 3 of 3 
Pure Maintenance

Mr Brandon Adams

596 w $750 \mathrm{~s}$

Suite $\mathbf{3 0 0}$
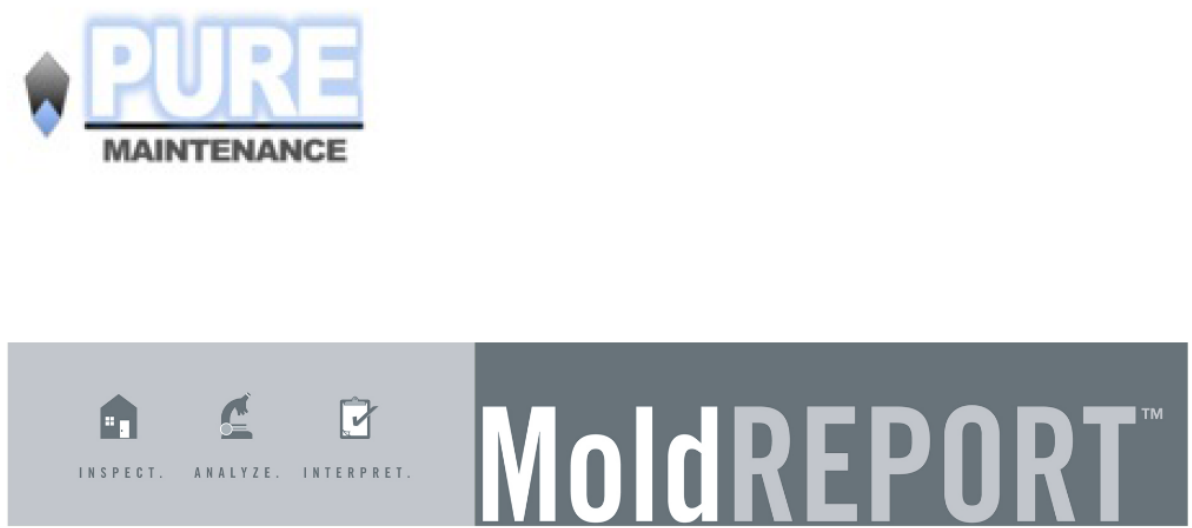

EMLab P \& K

WWW.MoldREPORT.com

info@MoldREPORT.com

Approved by:

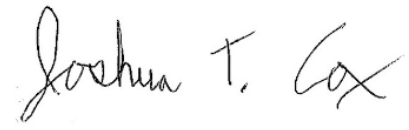

Operations Manager

Joshua Cox
Dates of Analysis:

MoldReport Direct exam: 06-28-2017

Service SOPs: MoldReport Direct exam (EM-MY-S-1039)

AlHA-LAP, LLC accredited service, Lab ID \#102297

All samples were received in acceptable condition unless noted in the Report Comments portion in the body of the report. Due to the nature of the analyses performed, field blank correction of results is not applied. The results relate only to the items tested.

EMLab P\&K ("the Company") shall have no liability to the client or the client's customer with respect to decisions or

recommendations made, actions taken or courses of conduct implemented by either the client or the client's customer as a result of or based upon the Test Results. In no event shall the Company be liable to the client with respect to the Test Results except for the Compary's own willful misconduct or gross negligence nor shall the Company be liable for incidental or consequential damages or lost profits or revenues to the fullest extent such liability may be disclaimed by law, even if the Company has been advised of the possibility of such damages, lost profits or lost revenues. In no event shall the Company's liability with respect to the Test Results exceed the amount paid to the Company by the client therefor. 
Client: Pure Maintenance Contact: Mr Brandon Adams Project: Mess Hall AT

Date of Sampling: 06-22-2017

Date of Receipt: 06-27-2017

Date of Report: 06-28-2017
MoldREPORT

EMLab P \& K

1501 West Knudsen Drive, Phoenix, AZ 85027 (800) 651-4802 Fax (623) 780-7695

\begin{tabular}{|c|c|c|c|}
\hline \multicolumn{4}{|c|}{ Laboratory Results } \\
\hline Location: & 7: Kitchen & 8: West Wall & 9: Divider Wall \\
\hline Comments (see below): & None & None & None \\
\hline Lab ID-Versionł: & $8171186-1$ & $8171187-1$ & $8171188-1$ \\
\hline \multicolumn{4}{|c|}{$\begin{array}{l}\text { Spore types present (indicative } \\
\text { of mold growth) } \S \text { : }\end{array}$} \\
\hline Aureobasidium & - & - & - \\
\hline Basidiospores & - & - & - \\
\hline Chaetomium & - & - & - \\
\hline Cladosporium & - & - & - \\
\hline Fusarium & - & - & - \\
\hline Lumber mold $\dagger$ & - & - & - \\
\hline Penicillium/Aspergillus types & - & - & - \\
\hline Stachybotrys & - & - & - \\
\hline Trichoderma & - & - & - \\
\hline Ulocladium & - & - & - \\
\hline \multicolumn{4}{|l|}{$\begin{array}{l}\text { Spore types present (not } \\
\text { indicative of mold growth)§: }\end{array}$} \\
\hline All spore types & - & - & - \\
\hline \multicolumn{4}{|l|}{ Other particles detected $\S:$} \\
\hline Skin cells & - & - & - \\
\hline Pollen & - & - & - \\
\hline $\begin{array}{l}\text { Background Debris and/or } \\
\text { Description }{ }^{* *} \text { : }\end{array}$ & Scant & Light & Light \\
\hline
\end{tabular}

\section{Comments: None}

Basidiomycetes: Commonly found outdoors. Occasionally may grow indoors, mostly as agents of wood decay.

Cladosporium: One of the most commonly found molds outdoors and frequently found growing indoors.

Penicillium/Aspergillus types: Penicllium and Aspergillus are among the most common molds found growing both indoors and out.

Stachybotrys and other marker types: Certain types of mold, such as Aureobasidium, Chaetomium, Fusarium, Trichoderma, and Ulocladium, are generally found in very low numbers outdoors. Consequently their presence indoors, even in relatively low numbers, is often an indication that these molds are originating from growth indoors. When present, these mold types are often the clearest indicator of a mold problem.

†Lumber mold: Fungi in the Ceratocystis/Ophiostoma group are commonly called "Lumber mold". Lumber mold is present on the wood framing of most homes that are built with lumber. Their presence alone is not in dicative of an indoor water problem.

(s) as Scant, Moderate, Heavy, or Very Heavy. Very heavy background debris may obscure visibility for the analyst. Some sample types are not graded for background debris, in which case a brief description of the material is reported.

graded for background deb" "V" in wher the reflected by the value of "x".

The limit of detection is $<1+$ when mold growth is detected.

§All readers are advised to refer to the document "Understanding Direct Microscopic Examination Results" which is available at our website

www.moldreport.com, or by request from the laboratory.

Aerotech Laboratories, Inc 
Pure Maintenance

Mr Brandon Adams

596 w $750 \mathrm{~s}$

Suite 300

Bountiful, UT 84010 USA

(801) 529-2976
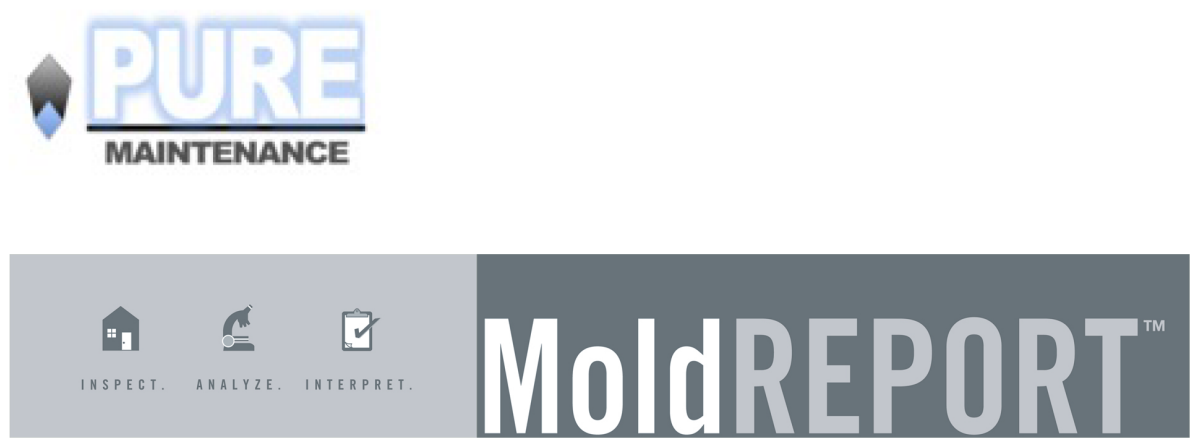

EMLab P \& K

www.MoldREPORT.com

$$
\text { info@MoldREPORT.com }
$$

Approved by:

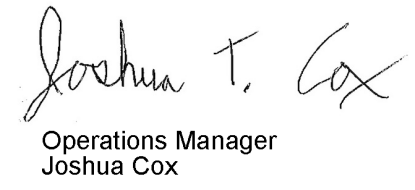

Dates of Analysis:

MoldReport Spore trap: 09-19-2017

Service SOPs: MoldReport Spore trap (EM-MY-S-1038)

AlHA-LAP, LLC accredited service, Lab ID \#102297

All samples were received in acceptable condition unless noted in the Report Comments portion in the body of the report. Due to the nature of the analyses performed, field blank correction of results is not applied. The results relate only to the items tested.

The analytical sensitivity is the spores $/ \mathrm{m}^{\wedge} 3$ divided by the raw count, expressed in spores $/ \mathrm{m}^{\wedge} 3$. The limit of detection is the analytical sensitivity (in spores $/ \mathrm{m}^{\wedge} 3$ ) multiplied by the sample volume (in liters) divided by 1000 liters.

EMLab P\&K ("the Company") shall have no liability to the client or the client's customer with respect to decisions or

recommendations made, actions taken or courses of conduct implemented by either the client or the client's customer as a result of or based upon the Test Results. In no event shall the Company be liable to the client with respect to the Test Results except for the Company's own willful misconduct or gross negligence nor shall the Company be liable for incidental or consequential damages or lost profits or revenues to the fullest extent such liability may be disclaimed by law, even if the Company has been advised of the possibility of such damages, lost profits or lost revenues. In no event shall the Company's liability with respect to the Test Results exceed the amount paid to the Company by the client therefor 
Client: Pure Maintenance

MoldREPORT

Contact: Mr Brandon Adams

EMLab P \& K
Phoenix, AZ 85027

Project: Mess Hall AT 6 Months
Date of Sampling: 09-12-2017

Date of Receipt: 09-18-2017

Date of Report: 09-19-2017

\section{Laboratory Results}

MoldREPORT: Spore Trap Analysis

\begin{tabular}{|c|c|c|c|c|c|c|}
\hline Location: & \multicolumn{2}{|c|}{$\begin{array}{c}1: \\
\text { NW Corner }\end{array}$} & \multicolumn{2}{|c|}{$\begin{array}{c}2: \\
\text { Sw Office }\end{array}$} & \multicolumn{2}{|c|}{$\begin{array}{c}3: \\
\text { Middle West }\end{array}$} \\
\hline Comments (see below) & \multicolumn{2}{|c|}{ None } & \multicolumn{2}{|c|}{ None } & \multicolumn{2}{|c|}{ None } \\
\hline Lab ID-Versiont: & \multicolumn{2}{|c|}{$8397804-1$} & \multicolumn{2}{|c|}{$8397805-1$} & \multicolumn{2}{|c|}{$8397806-1$} \\
\hline Analysis Date: & \multicolumn{2}{|c|}{$09 / 19 / 2017$} & \multicolumn{2}{|c|}{$09 / 19 / 2017$} & \multicolumn{2}{|c|}{$09 / 19 / 2017$} \\
\hline Spore types detected: & raw ct. & per $\mathrm{m} 3$ & raw ct. & per $\mathrm{m} 3$ & raw ct. & per $\mathrm{m} 3$ \\
\hline Aureobasidium & - & - & - & - & - & - \\
\hline Basidiospores & 16 & 850 & 16 & 850 & 17 & 910 \\
\hline Chaetomium & - & - & - & - & - & - \\
\hline Cladosporium & 7 & 370 & 11 & 590 & 11 & 590 \\
\hline Fusarium & - & - & - & - & - & - \\
\hline Penicillium/Aspergillus types & 5 & 270 & 28 & 1,500 & 4 & 210 \\
\hline Stachybotrys & - & - & - & - & - & - \\
\hline Trichoderma & - & - & - & - & - & - \\
\hline Ulocladium & - & - & - & - & - & - \\
\hline Others & 25 & 1,300 & 26 & 1,400 & 15 & 800 \\
\hline$\S$ Total: & & 2,800 & & 4,300 & & 2.500 \\
\hline \multicolumn{7}{|l|}{ Additional Information: } \\
\hline Hyphal fragments & \multicolumn{2}{|c|}{-} & \multicolumn{2}{|c|}{-} & \multicolumn{2}{|c|}{53} \\
\hline Skin cells & \multicolumn{2}{|c|}{$13-67$} & \multicolumn{2}{|c|}{$13-67$} & \multicolumn{2}{|c|}{$80-4,000$} \\
\hline Pollen & \multicolumn{2}{|c|}{$<13$} & \multicolumn{2}{|c|}{$<13$} & \multicolumn{2}{|c|}{$<13$} \\
\hline Background debris $(1-4) \dagger$ & \multicolumn{2}{|c|}{2} & \multicolumn{2}{|c|}{2} & \multicolumn{2}{|c|}{2} \\
\hline Limit of detection & \multicolumn{2}{|c|}{13} & \multicolumn{2}{|c|}{13} & \multicolumn{2}{|c|}{13} \\
\hline Sample volume (liters) & \multicolumn{2}{|c|}{75} & \multicolumn{2}{|c|}{75} & \multicolumn{2}{|c|}{75} \\
\hline
\end{tabular}

\section{Comments:}

Basidiospores (basidiomycetes): Basidiospores are extremely common outdoors and originate from fungi in gardens, forests, and woodlands. It is rare for the source of basidiospores to be indoors. However, basidiospores may be an indicator of wood decay.

Cladosporium: One of the most commonly found molds outdoors and frequently found growing indoors. Spores from Cladosporium are generally present in outdoor and indoor air, even in relatively clean, mold-growth-free, indoor environments. Levels vary based upon activity levels, weather conditions, dustiness, outside air exchange rates, and other factors.

Penicillium/Aspergillus types: Penicllium and Aspergillus are among the most common molds found growing both indoors and outdoors (even in relatively clean, mold-growth-free, indoor environments). Levels vary based upon activity levels, dustiness, weather conditions, outside air exchange rates, and other factors.

Stachybotrys and other marker types: Certain types of mold, such as Aureobasidium, Chaetomium, Fusarium, Trichoderma, and Ulocladium, are generally found in very low numbers outdoors. Consequently their presence indoors, even in relatively low numbers, is often an indication that these molds are originating from growth indoors. When present, these mold types are often the clearest indicator of a mold problem.

Others: Molds in the "Others" category are generally found outdoors in moderate numbers, and are therefore not considered markers of indoor growth.

† A "Version" indicated by -"x" after the Lab ID\# with a value greater than 1 indicates a sample with amended data. The revision number is reflected by the value of " $\mathrm{x}$ ".

+ Background debris is an indication of the amounts of non-biological particulate matter present on the slide (dust in the air) and is graded from 1 to 4 with 4 indicating the largest amounts.

The analytical sensitivity is the spores $/ \mathrm{m}^{\wedge} 3$ divided by the raw count, expressed in spores $/ \mathrm{m}^{\wedge} 3$. The limit of detection is the analytical sensitivity (in spores $/ \mathrm{m}^{\wedge} 3$ ) multiplied by the sample volume (in liters) divided by 1000 liters.

$\S$ Total has been rounded to two significant figures to reflect analytical precision.

Rer $0203 / 1$

Aerotech Laboratories, Inc

EMLab ID: 1795837, Page 2 of 3 
Client: Pure Maintenance

MoldREPORT

Contact: Mr Brandon Adams

EMLab P \& K
Phoenix, AZ 85027

Project: Mess Hall AT 6 Months

Date of Sampling: 09-12-2017

Date of Receipt: 09-18-2017

Date of Report: 09-19-2017

MoldREPORT: Spore Trap Analysis

\begin{tabular}{|c|c|c|c|c|}
\hline Location: & \multicolumn{2}{|c|}{$\begin{array}{c}4: \\
\text { South East Office }\end{array}$} & \multicolumn{2}{|c|}{$\begin{array}{c}5: \\
\text { Outside }\end{array}$} \\
\hline Comments (see below) & \multicolumn{2}{|c|}{ None } & \multicolumn{2}{|c|}{ None } \\
\hline Lab ID-Versiont: & \multicolumn{2}{|c|}{ 8397807-1 } & \multicolumn{2}{|c|}{$8397808-1$} \\
\hline Analysis Date: & \multicolumn{2}{|c|}{$09 / 19 / 2017$} & \multicolumn{2}{|c|}{$09 / 19 / 2017$} \\
\hline Spore types detected: & raw ct. & per m3 & raw ct. & per $m 3$ \\
\hline Aureobasidium & - & - & - & - \\
\hline Basidiospores & 15 & 800 & 148 & 7,900 \\
\hline Chaetomium & 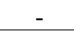 & - & 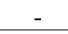 & - \\
\hline Cladosporium & 16 & 850 & 45 & 2,400 \\
\hline Fusarium & - & - & - & - \\
\hline Penicillium/Aspergillus types & 2 & 110 & 4 & 210 \\
\hline Stachybotrys & - & - & - & - \\
\hline Trichoderma & - & - & - & - \\
\hline Ulocladium & 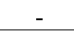 & - & - & - \\
\hline Others & 20 & 1,100 & 164 & 8,700 \\
\hline \& Total: & & 2.800 & & 19.000 \\
\hline \multicolumn{5}{|l|}{ Additional Information: } \\
\hline Hyphal fragments & \multicolumn{2}{|c|}{53} & \multicolumn{2}{|c|}{-} \\
\hline Skin cells & \multicolumn{2}{|c|}{$13-67$} & \multicolumn{2}{|c|}{$13-67$} \\
\hline Pollen & \multicolumn{2}{|c|}{$<13$} & \multicolumn{2}{|c|}{$<13$} \\
\hline Background debris $(1-4) \dagger$ & \multirow{2}{*}{\multicolumn{2}{|c|}{3}} & \multirow{2}{*}{\multicolumn{2}{|c|}{2}} \\
\hline Limit of detection & & & & \\
\hline Sample volume (liters) & \multicolumn{2}{|c|}{75} & \multicolumn{2}{|c|}{75} \\
\hline
\end{tabular}

\section{Comments:}

Basidiospores (basidiomycetes): Basidiospores are extremely common outdoors and originate from fungi in gardens, forests, and woodlands. It is rare for the source of basidiospores to be indoors. However, basidiospores may be an indicator of wood decay.

Cladosporium: One of the most commonly found molds outdoors and frequently found growing indoors. Spores from Cladosporium are generally present in outdoor and indoor air, even in relatively clean, mold-growth-free, indoor environments. Levels vary based upon activity levels, weather conditions, dustiness, outside air exchange rates, and other factors.

Penicillium/Aspergillus types: Penicllium and Aspergillus are among the most common molds found growing both indoors and outdoors (even in relatively clean, mold-growth-free, indoor environments). Levels vary based upon activity levels, dustiness, weather conditions, outside air exchange rates, and other factors

Stachybotrys and other marker types: Certain types of mold, such as Aureobasidium, Chaetomium, Fusarium, Trichoderma, and Ulocladium, are generally found in very low numbers outdoors. Consequently their presence indoors, even in relatively low numbers, is often an indication that these molds are originating from growth indoors. When present, these mold types are often the clearest indicator of a mold problem.

Others: Molds in the "Others" category are generally found outdoors in moderate numbers, and are therefore not considered markers of indoor growth.

† A "Version" indicated by -"x" after the Lab ID\# with a value greater than 1 indicates a sample with amended data. The revision number is reflected by the value of " $\mathrm{x}$ ".

$t$ Background debris is an indication of the amounts of non-biological particulate matter present on the slide (dust in the air) and is graded from 1 to 4 with 4 indicating the largest amounts.

The analytical sensitivity is the spores $/ \mathrm{m}^{\wedge} 3$ divided by the raw count, expressed in spores $/ \mathrm{m}^{\wedge} 3$. The limit of detection is the analytical sensitivity (in spores $/ \mathrm{m}^{\wedge} 3$ ) multiplied by the sample volume (in liters) divided by 1000 liters.

$\S$ Total has been rounded to two significant figures to reflect analytical precision.

Rer $0203 / 1$

Aerotech Laboratories, Inc

EMLab ID: 1795837, Page 3 of 3 


\section{Pure Maintenance \\ Mr Brandon Adams \\ 596 w $750 \mathrm{~s}$}

Suite 300
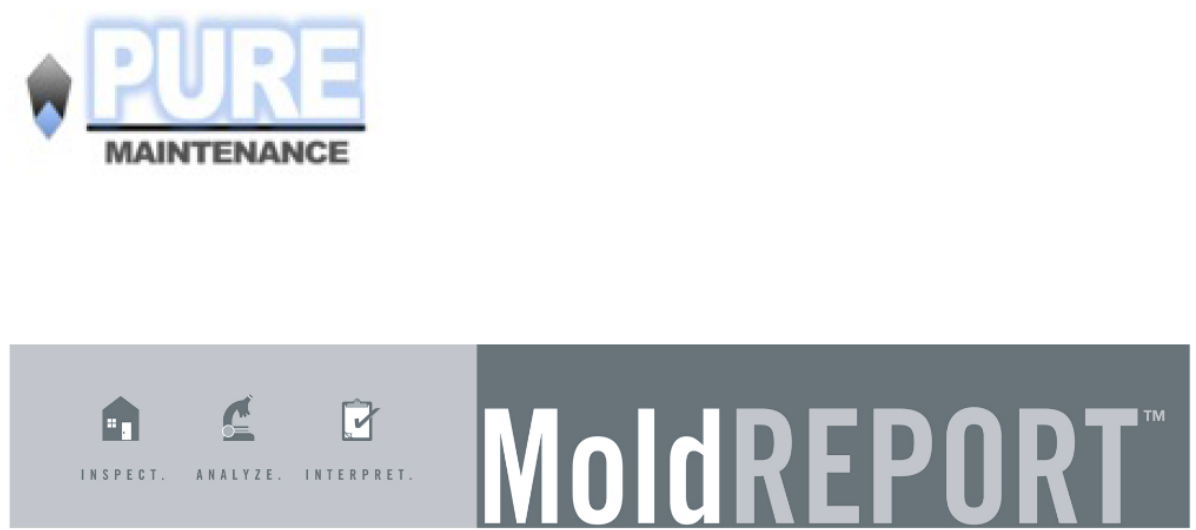

EMLab P \& K

WWW.MoldREPORT.com

info@MoldREPORT.com

Approved by:

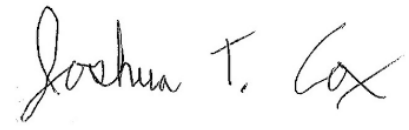

Operations Manager

Joshua Cox
Dates of Analysis:

MoldReport Direct exam: 09-19-2017

Service SOPs: MoldReport Direct exam (EM-MY-S-1039)

AlHA-LAP, LLC accredited service, Lab ID \#102297

All samples were received in acceptable condition unless noted in the Report Comments portion in the body of the report. Due to the nature of the analyses performed, field blank correction of results is not applied. The results relate only to the items tested.

EMLab P\&K ("the Company") shall have no liability to the client or the client's customer with respect to decisions or

recommendations made, actions taken or courses of conduct implemented by either the client or the client's customer as a result of or based upon the Test Results. In no event shall the Company be liable to the client with respect to the Test Results except for the Comparry's own willful misconduct or gross negligence nor shall the Company be liable for incidental or consequential damages or lost profits or revenues to the fullest extent such liability may be disclaimed by law, even if the Company has been advised of the possibility of such damages, lost profits or lost revenues. In no event shall the Company's liability with respect to the Test Results exceed the amount paid to the Company by the client therefor. 
Client: Pure Maintenance Contact: Mr Brandon Adams Project: Mess Hall AT 6 Months Date of Sampling: 09-12-2017 Date of Receipt: 09-18-2017

Date of Report: 09-19-2017
MoldREPORT

EMLab P \& K

1501 West Knudsen Drive, Phoenix, AZ 85027 (800) 651-4802 Fax (623) 780-7695

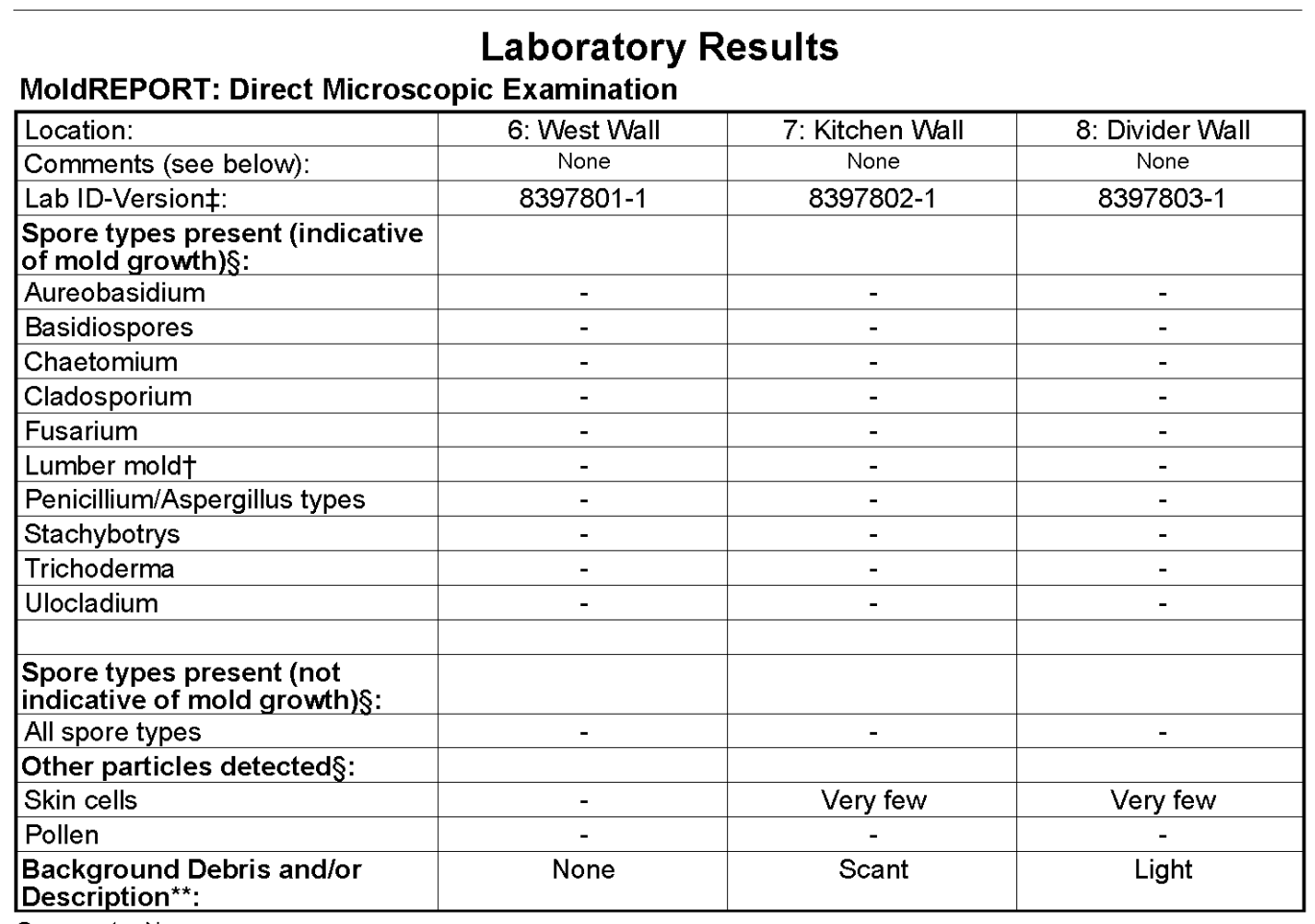

Comments: None

Basidiomycetes: Commonly found outdoors. Occasionally may grow indoors, mostly as agents of wood decay.

Cladosporium: One of the most commonly found molds outdoors and frequently found growing indoors.

Penicillium/Aspergillus types: Penicllium and Aspergillus are among the most common molds found growing both indoors and out.

Stachybotrys and other marker types: Certain types of mold, such as Aureobasidium, Chaetomium, Fusarium, Trichoderma, and Ulocladium, are generally found in very low numbers outdoors. Consequently their presence indoors, even in relatively low
numbers, is often an indication that these molds are originating from growth indoors. When present, these mold types are often the numbers, is often an indication that thes
clearest indicator of a mold problem.

†Lumber mold: Fungi in the Ceratocystis/Ophiostoma group are commonly called "Lumber mold". Lumber mold is present on the wood framing of most homes that are built with lumber. Their presence alone is not in dicative of an indoor water problem.

(baterial is graded and described as Scant, Moderate, Heavy, or Very Heavy. Very heavy background debris may obscure visibility for the analyst. Some sample types are not graded for background debris, in which case a brief description of the material is reported.

gra "Version" indicated by " "x" after the Lab ID\#" with a value greater than 1 indicates a sample with amended data. The revision number is reflected by the value of "x"

The limit of detection is $<1+$ when mold growth is detected.

§All readers are advised to refer to the document "Understanding Direct Microscopic Examination Results" which is available at our website

Www.moldreport.com, or by request from the laboratory.

Aerotech Laboratories, Inc 
Pure Maintenance

Mr Brandon Adams

596 w $750 \mathrm{~s}$

Suite 300

Bountiful, UT 84010 USA

(801) 529-2976
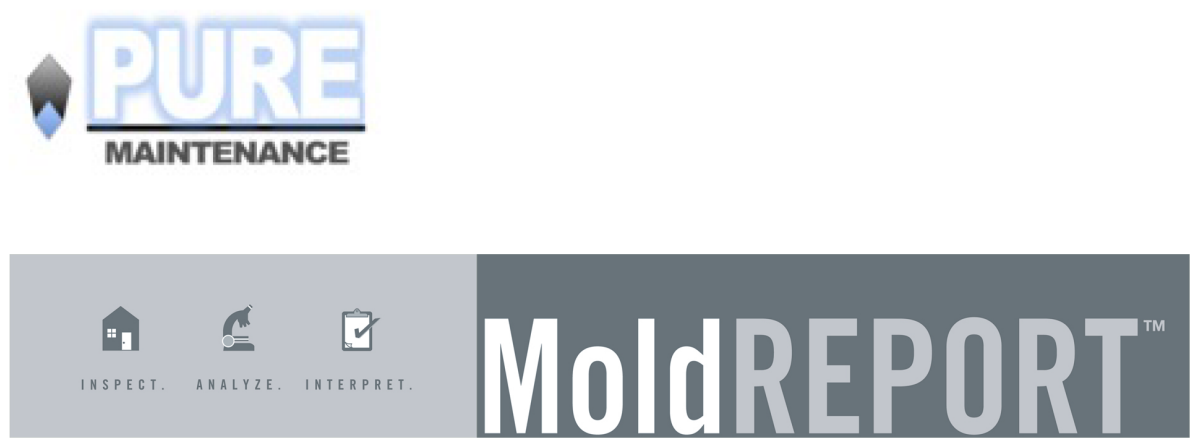

EMLab P \& K

WwW.MoldREPORT.com

$$
\text { info@MoldREPORT.com }
$$

Approved by:

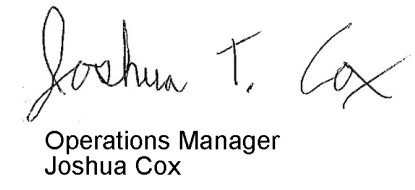

Dates of Analysis:

MoldReport Spore trap: 09-19-2017 and 09-19-2017

Service SOPs: MoldReport Spore trap (EM-MY-S-1038)

AlHA-LAP, LLC accredited service, Lab ID \#102297

All samples were received in acceptable condition unless noted in the Report Comments portion in the body of the report. Due to the nature of the analyses performed, field blank correction of results is not applied. The results relate only to the items tested.

The analytical sensitivity is the spores $/ \mathrm{m}^{\wedge} 3$ divided by the raw count, expressed in spores $/ \mathrm{m}^{\wedge} 3$. The limit of detection is the analytical sensitivity (in spores $/ \mathrm{m}^{\wedge} 3$ ) multiplied by the sample volume (in liters) divided by 1000 liters.

EMLab P\&K ("the Company") shall have no liability to the client or the client's customer with respect to decisions or

recommendations made, actions taken or courses of conduct implemented by either the client or the client's customer as a result of or based upon the Test Results. In no event shall the Company be liable to the client with respect to the Test Results except for the Company's own willful misconduct or gross negligence nor shall the Company be liable for incidental or consequential damages or lost profits or revenues to the fullest extent such liability may be disclaimed by law, even if the Company has been advised of the possibility of such damages, lost profits or lost revenues. In no event shall the Company's liability with respect to the Test Results exceed the amount paid to the Company by the client therefor 
Client: Pure Maintenance

Contact: Mr Brandon Adams

MoldREPORT

Project: Hammerhead 6 Months AT

EMLab P \& K

Date of Sampling: 09-12-2017

Date of Receipt: 09-18-2017

Date of Report: 09-19-2017

\section{Laboratory Results}

MoldREPORT: Spore Trap Analysis

\begin{tabular}{|c|c|c|c|c|}
\hline Location: & \multicolumn{2}{|c|}{$\begin{array}{c}1: \\
\text { Northwest Classroom }\end{array}$} & \multicolumn{2}{|c|}{$\begin{array}{c}2: \\
\text { Mens Restroom }\end{array}$} \\
\hline Comments (see below) & \multicolumn{2}{|c|}{ None } & \multicolumn{2}{|c|}{ None } \\
\hline Lab ID-Versiont: & \multicolumn{2}{|c|}{$8397836-1$} & \multicolumn{2}{|c|}{$8397837-1$} \\
\hline Analysis Date: & \multicolumn{2}{|c|}{$09 / 19 / 2017$} & \multicolumn{2}{|c|}{$09 / 19 / 2017$} \\
\hline Spore types detected: & raw ct. & per m3 & raw ct. & per $\mathrm{m} 3$ \\
\hline Aureobasidium & - & - & - & - \\
\hline Basidiospores & 2 & 27 & 1 & 53 \\
\hline Chaetomium & - & - & - & - \\
\hline Cladosporium & - & - & - & - \\
\hline Fusarium & - & - & - & - \\
\hline Penicillium/Aspergillus types & 1 & 13 & 2 & 110 \\
\hline Stachybotrys & - & - & - & - \\
\hline Trichoderma & - & - & - & - \\
\hline Ulocladium & - & - & - & - \\
\hline Others & 4 & 53 & 1 & 53 \\
\hline \& Total: & & 93 & & 210 \\
\hline \multicolumn{5}{|l|}{ Additional Information: } \\
\hline Hyphal fragments & \multicolumn{2}{|c|}{ 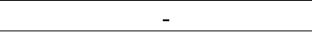 } & \multicolumn{2}{|c|}{-} \\
\hline Skin cells & \multicolumn{2}{|c|}{$13-67$} & \multicolumn{2}{|c|}{$13-67$} \\
\hline Pollen & \multicolumn{2}{|c|}{$<13$} & \multicolumn{2}{|c|}{$<13$} \\
\hline Background debris $(1-4) \dagger$ & \multirow{2}{*}{\multicolumn{2}{|c|}{$\frac{1}{13}$}} & \multicolumn{2}{|c|}{2} \\
\hline Limit of detection & & & \multirow{2}{*}{\multicolumn{2}{|c|}{$\frac{13}{75}$}} \\
\hline Sample volume (liters) & \multicolumn{2}{|c|}{75} & & \\
\hline
\end{tabular}

\section{Comments:}

Basidiospores (basidiomycetes): Basidiospores are extremely common outdoors and originate from fungi in gardens, forests, and woodlands. It is rare for the source of basidiospores to be indoors. However, basidiospores may be an indicator of wood decay.

Cladosporium: One of the most commonly found molds outdoors and frequently found growing indoors. Spores from Cladosporium are generally present in outdoor and indoor air, even in relatively clean, mold-growth-free, indoor environments. Levels vary based upon activity levels, weather conditions, dustiness, outside air exchange rates, and other factors.

Penicillium/Aspergillus types: Penicllium and Aspergillus are among the most common molds found growing both indoors and outdoors (even in relatively clean, mold-growth-free, indoor environments). Levels vary based upon activity levels, dustiness, weather conditions, outside air exchange rates, and other factors.

Stachybotrys and other marker types: Certain types of mold, such as Aureobasidium, Chaetomium, Fusarium, Trichoderma, and Ulocladium, are generally found in very low numbers outdoors. Consequently their presence indoors, even in relatively low numbers, is often an indication that these molds are originating from growth indoors. When present, these mold types are often the clearest indicator of a mold problem.

Others: Molds in the "Others" category are generally found outdoors in moderate numbers, and are therefore not considered markers of indoor growth.

† A "Version" indicated by -"x" after the Lab ID\# with a value greater than 1 indicates a sample with amended data. The revision number is reflected by the value of " $\mathrm{x}$ ".

† Background debris is an indication of the amounts of non-biological particulate matter present on the slide (dust in the air) and is graded from 1 to 4 with 4 indicating the largest amounts.

The analytical sensitivity is the spores $/ \mathrm{m}^{\wedge} 3$ divided by the raw count, expressed in spores $/ \mathrm{m}^{\wedge} 3$. The limit of detection is the analytical sensitivity (in spores $/ \mathrm{m}^{\wedge} 3$ ) multiplied by the sample volume (in liters) divided by 1000 liters.

$\S$ Total has been rounded to two significant figures to reflect analytical precision

Rer 02 03/11

Aerotech Laboratories, Inc

EMLab ID: 1795834, Page 2 of 3 
Client: Pure Maintenance

Contact: Mr Brandon Adams

MoldREPORT

Project: Hammerhead 6 Months AT

EMLab P \& K

Date of Sampling: 09-12-2017

Date of Receipt: 09-18-2017

Date of Report: 09-19-2017

MoldREPORT: Spore Trap Analysis

\begin{tabular}{|c|c|c|c|c|}
\hline Location: & \multicolumn{2}{|c|}{$\begin{array}{c}3: \\
\text { Basement }\end{array}$} & \multicolumn{2}{|c|}{$\begin{array}{c}\text { 4: } \\
\text { Outside }\end{array}$} \\
\hline Comments (see below) & \multicolumn{2}{|c|}{ None } & \multicolumn{2}{|c|}{ None } \\
\hline Lab ID-Version\$: & \multicolumn{2}{|c|}{$8397838-1$} & \multicolumn{2}{|c|}{$8397839-1$} \\
\hline Analysis Date: & \multicolumn{2}{|c|}{$09 / 19 / 2017$} & \multicolumn{2}{|c|}{$09 / 19 / 2017$} \\
\hline Spore types detected: & raw ct. & per m3 & raw ct. & per m3 \\
\hline Aureobasidium & - & - & - & - \\
\hline Basidiospores & 52 & 2,800 & 193 & 10,000 \\
\hline Chaetomium & - & - & - & - \\
\hline Cladosporium & 8 & 430 & 13 & 690 \\
\hline Fusarium & - & - & - & - \\
\hline Penicillium/Aspergillus types & 75 & 4,000 & 1 & 53 \\
\hline Stachybotrys & - & - & - & - \\
\hline Trichoderma & - & - & - & - \\
\hline Ulocladium & - & - & - & - \\
\hline Others & 55 & 2,900 & 164 & 8,700 \\
\hline$\S$ Total: & & 10,000 & & 20,000 \\
\hline \multicolumn{5}{|l|}{ Additional Information: } \\
\hline Hyphal fragments & \multicolumn{2}{|c|}{-} & \multicolumn{2}{|c|}{ - } \\
\hline Skin cells & \multicolumn{2}{|c|}{$13-67$} & \multicolumn{2}{|c|}{$13-67$} \\
\hline Pollen & \multicolumn{2}{|c|}{$<13$} & \multicolumn{2}{|c|}{53} \\
\hline Background debris $(1-4)^{\dagger}$ & \multicolumn{2}{|c|}{1} & \multicolumn{2}{|c|}{1} \\
\hline Limit of detection & \multicolumn{2}{|c|}{13} & \multicolumn{2}{|c|}{13} \\
\hline Sample volume (liters) & \multicolumn{2}{|c|}{75} & \multicolumn{2}{|c|}{75} \\
\hline
\end{tabular}

Sample volume (liters)

Laboratory Results

Comments:

Basidiospores (basidiomycetes): Basidiospores are extremely common outdoors and originate from fungi in gardens, forests, and woodlands. It is rare for the source of basidiospores to be indoors. However, basidiospores may be an indicator of wood decay.

Cladosporium: One of the most commonly found molds outdoors and frequently found growing indoors. Spores from Cladosporium are generally present in outdoor and indoor air, even in relatively clean, mold-growth-free, indoor environments. Levels vary based upon activity levels, weather conditions, dustiness, outside air exchange rates, and other factors.

Penicillium/Aspergillus types: Penicllium and Aspergillus are among the most common molds found growing both indoors and outdoors (even in relatively clean, mold-growth-free, indoor environments). Levels vary based upon activity levels, dustiness, weather conditions, outside air exchange rates, and other factors.

Stachybotrys and other marker types: Certain types of mold, such as Aureobasidium, Chaetomium, Fusarium, Trichoderma, and Ulocladium, are generally found in very low numbers outdoors. Consequently their presence indoors, even in relatively low numbers, is often an indication that these molds are originating from growth indoors. When present, these mold types are often the clearest indicator of a mold problem.

Others: Molds in the "Others" category are generally found outdoors in moderate numbers, and are therefore not considered markers of indoor growth.

† A "Version" indicated by -"x" after the Lab ID\# with a value greater than 1 indicates a sample with amended data. The revision number is reflected by the value of " $\mathrm{x}$ ".

+ Background debris is an indication of the amounts of non-biological particulate matter present on the slide (dust in the air) and is graded from 1 to 4 with 4 indicating the largest amounts.

The analytical sensitivity is the spores $/ \mathrm{m}^{\wedge} 3$ divided by the raw count, expressed in spores $/ \mathrm{m}^{\wedge} 3$. The limit of detection is the analytical sensitivity (in spores $/ \mathrm{m}^{\wedge} 3$ ) multiplied by the sample volume (in liters) divided by 1000 liters.

$\S$ Total has been rounded to two significant figures to reflect analytical precision.

R.er 02 03/11

Aerotech Laboratories, Inc

EMLab ID: 1795834 , Page 3 of 3 


\section{Pure Maintenance \\ Mr Brandon Adams \\ 596 w $750 \mathrm{~s}$}

Suite 300
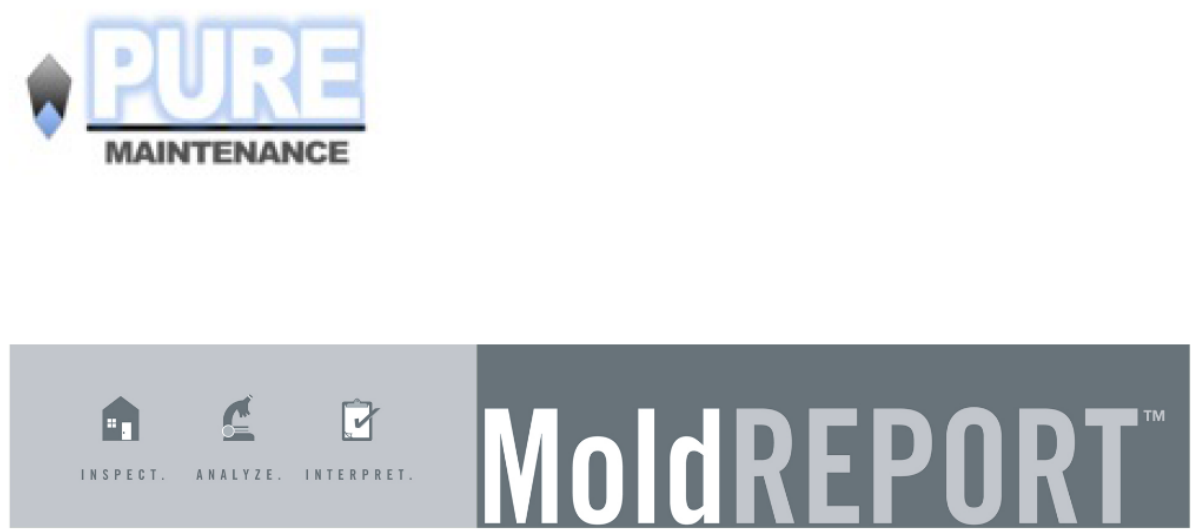

EMLab P \& K

WWW.MoldREPORT.com

info@MoldREPORT.com

Approved by:

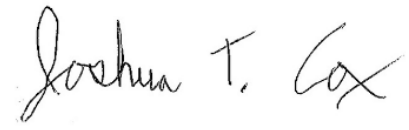

Operations Manager

Joshua Cox
Dates of Analysis:

MoldReport Direct exam: 09-19-2017

Service SOPs: MoldReport Direct exam (EM-MY-S-1039)

AlHA-LAP, LLC accredited service, Lab ID \#102297

All samples were received in acceptable condition unless noted in the Report Comments portion in the body of the report. Due to the nature of the analyses performed, field blank correction of results is not applied. The results relate only to the items tested.

EMLab P\&K ("the Company") shall have no liability to the client or the client's customer with respect to decisions or

recommendations made, actions taken or courses of conduct implemented by either the client or the client's customer as a result of or based upon the Test Results. In no event shall the Company be liable to the client with respect to the Test Results except for the Compary's own willful misconduct or gross negligence nor shall the Company be liable for incidental or consequential damages or lost profits or revenues to the fullest extent such liability may be disclaimed by law, even if the Company has been advised of the possibility of such damages, lost profits or lost revenues. In no event shall the Company's liability with respect to the Test Results exceed the amount paid to the Company by the client therefor. 
Client: Pure Maintenance Contact: Mr Brandon Adams Project: Hammerhead 6 Months AT Date of Sampling: 09-12-2017

Date of Receipt: 09-18-2017

Date of Report: 09-19-2017
MoldREPORT

EMLab P \& K

1501 West Knudsen Drive, Phoenix, AZ 85027 (800) 651-4802 Fax (623) 780-7695

\begin{tabular}{|c|c|c|c|}
\hline \multicolumn{4}{|c|}{ Laboratory Results } \\
\hline Location: & 5: Basement & 6: Mens Bathroom & 7: NW Classroom \\
\hline Comments (see below): & None & None & None \\
\hline Lab ID-Versionł: & $8397833-1$ & $8397834-1$ & $8397835-1$ \\
\hline \multicolumn{4}{|c|}{$\begin{array}{l}\text { Spore types present (indicative } \\
\text { of mold growth) } \$ \text { : }\end{array}$} \\
\hline Aureobasidium & - & - & - \\
\hline Basidiospores & - & - & - \\
\hline Chaetomium & - & - & - \\
\hline Cladosporium & - & - & - \\
\hline Fusarium & - & - & - \\
\hline Lumber mold $\dagger$ & - & - & - \\
\hline Penicillium/Aspergillus types & - & - & - \\
\hline Stachybotrys & - & - & - \\
\hline Trichoderma & - & - & - \\
\hline Ulocladium & - & - & - \\
\hline \multicolumn{4}{|l|}{$\begin{array}{l}\text { Spore types present (not } \\
\text { indicative of mold growth)s: }\end{array}$} \\
\hline All spore types & Very few & Very few & Few \\
\hline \multicolumn{4}{|l|}{ Other particles detected§: } \\
\hline Skin cells & Few & Very few & Few \\
\hline Pollen & - & - & Very few \\
\hline $\begin{array}{l}\text { Background Debris and/or } \\
\text { Description }{ }^{\star *} \text { : }\end{array}$ & Moderate & Moderate & Moderate \\
\hline
\end{tabular}

Comments: None

Basidiomycetes: Commonly found outdoors. Occasionally may grow indoors, mostly as agents of wood decay.

Cladosporium: One of the most commonly found molds outdoors and frequently found growing indoors.

Penicillium/Aspergillus types: Penicllium and Aspergillus are among the most common molds found growing both indoors and out.

Stachybotrys and other marker types: Certain types of mold, such as Aureobasidium, Chaetomium, Fusarium, Trichoderma, and Ulocladium, are generally found in very low numbers outdoors. Consequently their presence indoors, even in relatively low numbers, is often an indication that these molds are originating from growth indoors. When present, these mold types are often the clearest indicator of a mold problem.

†Lumber mold: Fungi in the Ceratocystis/Ophiostoma group are commonly called "Lumber mold". Lumber mold is present on the wood framing of most homes that are built with lumber. Their presence alone is not in dicative of an indoor water problem.

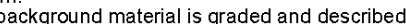
as Scant, Moderate, Heavy, or Very Heavy. Very heavy background debris may obscure visibility for the analyst. Some sample types are not graded for background debris, in which case a brief description of the material is reported.

gra "Version" indicated by "x" i wer the Lab ID\#" with a value greater than 1 indicates a sample with amended data. The revision number is reflected by the value of "x"

The limit of detection is $<1+$ when mold growth is detected.

§All readers are advised to refer to the document "Understanding Direct Microscopic Examination Results" which is available at our website

www.moldreport.com, or by request from the laboratory.

Aerotech Laboratories, Inc 


\section{Appendix B: Laboratory Analytical Reports}

\begin{tabular}{l}
$\begin{array}{c}\text { Material Safety Data Sheet PM } 2301 \\
\text { InstaPURE Cold Sterilant }\end{array}$ \\
\hline Compilation date: 15 April 2009 \\
\hline
\end{tabular}

\section{Identification of Product and Company}

Product name:

Article numbers:

Application:

78397-982 / 78397-983 / 78398-229/78400-377

REACH:

Disinfection liquid

Company name

05-2117310704-54-0000

Phone:

Fax:

E-mail:

info@puremaintenance.com

Home page:

Emergency Number: $\quad$ CHEMTREC +1-703-527-3887

02. Hazards Identification

\begin{tabular}{|l|l|l|l|l|}
\multicolumn{1}{l}{ Component } & \multicolumn{1}{l}{ CAS } & \multicolumn{2}{l}{ Amount w/w [\%] } & \multicolumn{1}{l}{ Symbol/ R-phrases } \\
\hline Hydrogen Peroxide & $231-765-0$ & $7722-84-1$ & $20-24$ & O, C, R 22-41 \\
\hline Peracetic Acid & $201-186-8$ & $79-21-0$ & $4-6$ & Xi, R 34 \\
\hline Acetic Acid & $200-580-7$ & $64-19-7$ & $8-10$ & Xi, R 36/38 \\
\hline
\end{tabular}

\section{Composition/Information on Ingredients}

The product is an Oxidizer and Corrosive that can cause burns. Direct contact could cause irreversible damage to eyes and skin tissue. Irritating to the respiratory system.

\section{First Aid Measures}

\section{General}

If clothing is contaminated, remove clothing, and wash clothing before reusing.

\section{Eyes and skin}

Flush immediately with excess water for at least 15 minutes. If burn or irritation has occurred, seek medical attention.

Ingestion

Drink large amounts of water. Do not induce

vomiting. Seek medical attention if necessary.

\section{Inhalation}

Move to fresh air and breathe deeply. Seek medical attention if necessary.

\section{Fire Fighting Measures}

Extinguishing Media

Water spray / Foam / $\mathrm{CO}_{2} /$ dry chemicals

Extinguishing Media to Avoid

Direct water jet.
Exposure Risks from Combustion Product /

Gases

Danger of developing toxic Pyrolyse products.

Special Equipment for Fire-fighters

Protect the respiratory ways. Use visors and gloves.

Additional Measures

Cool risky containers with water spray. Damaged products and contaminated water shall be disposed according to local laws and requirements.

\section{Accidental Release Measures}

\section{Personal Precautions}

Put on eye protection, protective gloves, boots, clothing and a respirator if air contamination is above the permitted levels. Arrange sufficient ventilation of air.

People should move away from any vapors in the contaminated area.

\section{Environmental Precautions}

In case of accidental spillage, contain the spill and neutralize it with sodium bicarbonate or sodium carbonate.

If allowed by local legislation:

Flush spill to the sewer. If mops, towels, paper towel or similar material is used, insure that these items are thoroughly rinsed with large amounts of water. Do not reuse the liquid material. 
Material Safety Data Sheet

InstaPURE Cold Sterilant

Compilation date: 15 April 2009

\section{Handling and Storage}

\section{Handling}

Keep container closed by using a vented cap. Do not transfer product from original container and once the product has been removed, do not return to the original container. Exhaust required at point of use.

\section{Fire- and Explosion}

Degradation of this product produces oxygen; keep away from heating/ignition sources. Do not smoke.

\section{Storage}

Store in a cool dry area (below $24^{\circ} \mathrm{C}$ ) away from heating sources. Heating will lead to pressure increase and danger of bursting the container. Floor needs a protective coating against acid.

\section{Combined Storage}

Do not store with flammable materials, metals, oxidizing or caustic materials.

\section{Exposure Controls/Personal Protection}

Technical Measures

Assure sufficient air exhaust and supply of fresh air.

\begin{tabular}{|l|}
\hline Exposure limits at work place Component \\
\hline Acetic Acid \\
MAKJTLV: 10ppm, MAK/TLV: $25 \mathrm{mg} / \mathrm{m} 3$, \\
$\mathrm{F}=1=(\mathrm{DFG}, \mathrm{EU})$ \\
Hydrogen Peroxide \\
MAKJTLV: 1ppm, MAK/TLV: $1,4 \mathrm{mg} / \mathrm{m} 3$, \\
$\mathrm{F}=1=(\mathrm{DFG})$ \\
\hline MAK $=$ maximum work place concentration, \\
TLV $=$ Threshold Limit Value, \\
$\mathrm{F}=$ Factor, Short Limit value. \\
\hline
\end{tabular}

\section{Respiratory protection}

If air contamination is above the permitted levels, use a mask for acid vapors, Combination filter B-P2.

\section{Hand protection}

Protective gloves. (e.g. nitrite, latex, neoprene) Refer to glove manufacturer specifications for compatibility.

Eye protection

Safety glasses or goggles. A face shield should be worn when splashes are likely.

\section{Skin protection}

Protective apron should be worn when splashes are likely. Rubber boots should be used for spill response.
General Measures

Avoid contact with eyes and skin. Do not breathe gases / vapors / aerosols.

\section{Hygienic Measures}

Do not eat, drink, or smoke. Immediately remove contaminated clothing. Wash hands before breaks and at end of shift. Preventive hand care by hand crème.

Limitation and Monitoring of Environmental Emission

Not determined

\section{Physical and Chemical Properties}

$\begin{array}{ll}\text { Physical state: } & \text { liquid } \\ \text { Appearance: } & \text { clear } \\ \text { Odor: } & \text { acid, pungent } \\ \text { pH: } & 0,8 \pm 0,3 \\ \text { Boiling point }\left[{ }^{\circ} \mathbf{C}\right]: & \text { Not determined } \\ \text { Flashing point }\left[{ }^{\circ} \mathbf{C}\right]: & \text { Not determined } \\ \text { Ignition conditions: } & \text { Not determined } \\ \text { Lower explosion limit: } & \text { Not determined } \\ \text { Upper explosion limit: } & \text { Not determined } \\ \text { Fire fortifying: } & \text { Yes } \\ \text { Vapor pressure at } \mathbf{5 0} 0^{\circ} \mathbf{C} \text { [kPA]: } & <110 \\ \text { Vapor density [g/ml]: } & \text { Not determined } \\ \text { Specific gravity }\left(\mathbf{H}_{2} \mathbf{O}\right) \text { [kg/l]: } & 1.090-1.140 \\ \text { Solubility in water }(\mathbf{b y} \text { weight): } & \text { complete } \\ \text { Ratio n-Octanol } / \mathbf{W a t e r :} & \text { Not determined } \\ \text { Viscosity: } & \text { Not determined } \\ \text { Relative vapour density } & \\ \text { relative to air: } & \text { Not determined } \\ \text { Evaporation rate: } & \text { Not determined } \\ \text { Freezing point }\left[{ }^{\circ} \mathbf{C}\right]: & \text { Not determined } \\ \text { Melting point }\left[{ }^{\circ} \mathbf{C}\right]: & \text { Not determined } \\ \text { Self-reactivity: } & \text { Not a self reactive } \\ & \text { substance }\end{array}$

\section{Stability and Reactivity}

\section{Materials to Avoid}

Avoid heavy metals including iron, copper, copper alloys brass and aluminium, salts, flammable organics, alkalis, caustics, chlorine and formaldehyde.

\section{Stability}

Product is stable.

\section{Conditions to Avoid}

Avoid direct sunlight, heat and hot storage $\left(>24^{\circ} \mathrm{C}\right)$.

Hazardous Decomposition

Oxygen \& Heat. Do not mix with chlorinated products as this could liberate toxic corrosive chlorine gas. 
Material Safety Data Sheet

InstaPURE, Cold Sterilant

Hazardous Polymerisation

Will not occur

\section{Toxicological Information}

Effects from Eye Contact

Corrosive (Eye Burns): Signs/symptoms may include cloudy appearance of the cornea

chemical burns, severe pain, tearing,

significantly impaired vision or potentially a

complete loss of vision

\section{Effects from Skin Contact}

Corrosive (Skin Burns): Signs/symptoms may include turning the skin chalky white, swelling, itching, intense pain, blistering, and potential tissue destruction.

Effects from Inhalation

Upper Respiratory Tract Irritation: Signs/

symptoms may include cough, sneezing, nasal

discharge, headache, hoarseness, and nose and throat pain.

Effects from Ingestion:

Gastrointestinal Irritation: Signs/symptoms may include abdominal pain, nausea, diarrhea and vomiting.

12. Environmental Information

This product has been tested and determined to be toxic to fish and aquatic invertebrates:

- Daphnia Magna / Water Flea: LC50 2.61 mg ai/L - Rainbow Trout: LC50 $6.68 \mathrm{mg}$ ai/L

- Bluegill: LC50 $4.25 \mathrm{mg}$ ai/L

\section{Disposal Considerations}

\section{Product Disposal}

Dispose of this product in accordance with all applicable European and Local regulations.

Disposal of Bottle and Packaging

Bottles and packaging can be disposed according European and Local regulations. Bottles should be thoroughly rinsed before disposal
14. Transportation Information

14.1 Classification according to ADR

ADR class:

Proper Shipping Name: UN3149 Hydrogen

Peroxide and Peracetic Acid Mixture, Stabilized

$5.1(8) \|$

Fac:or, ADR 1.1.3.6: $\quad 3$

Trarispuni Emergency

Card:

Labeling:

UN 3149

LQ, ADR 3.4.6:

58

Vapor pressure [kPa]: $\quad<110,\left[50^{\circ} \mathrm{C}\right]$

14.2 Classification according to IMDG

IMDG-Code Number: $\quad 5.1$

Proper Shipping Name: Hydrogen Peroxide and Peracetic Acid Mixture, Stabilized 5.18 UN 3149 ॥

Classification: Hydrogen Peroxide and

Peracetic Acid Mixture,

Stabilized UN 3149

EmS:

Labeling:

5. $1-02$

LQ, ADR [l/kg]

$5.1 \& 8$

0,5

14.3 Classification according to IATA

Forbidden for transported by air.

\section{Regulatory Information}

The product is classified and marked according to EC-Guidelines

In accordance with Directives 67/548/EEC and $1999 / 45 / E C$ this product is classified as corrosive and oxidising,

Risk Phrases

R 22: Harmful if swallowed.

R 34: Causes burns.

R 36/38: Irritating to eyes and skin.

R 41: Risk of serious damage to eyes. 
Material Safety Data Sheet

InstaPURE Cold Sterilant

Compilation date: 15 April 2009

\section{Safety Phrases}

$S 3 / 7$ : Keep container tightly closed in a cool

place. Only use vented caps.

S 14: Keep away from identified in Section 7 :

Handling and Storage.

S 23: Do not breathe gas/fumes/vapour/spray.

$S 26$ : In case of contact with the eyes, rinse

immediately with plenty of water and seek

medical advice.

$S$ 28: After contact with skin immediately flush

affect area with copious amounts of water

S 36/37/39: Wear suitable protective clothing,

gloves and eye/face protection

S45: In case of accident or if you feel unwell,

seek medical advice immediately (show the

label where possible).

S 61: Avoid release to the environment. Refer to

Section 13: Disposal Considerations.

\section{National Legislation}

Follow all relevant national laws or other national relevant measures

\section{Other information}

The information provided in this Material Safety Data Sheet is correct to the best of our knowledge. This information given is designed only as guidance for safe handling, use,

processing, storage, transportation, disposal and

release and is not to be considered a warranty

or quality specification. The information relates only to the specific material designated in this document and may not be valid if the product is used in combination with any other materials or processes, unless specified in the text.

\section{Guidelines}

-2001/58/EC

- 67/548/EEC

-1999/45/EC

- 91/689/EEC

- 1907/2006/EC

- ADR (2003)

- IMDG-Code (30. Amdt.)

- IATA-DGR (2003) 


\section{EverPURE}

\section{MATERIAL SAFETY DATA SHEET}

I. IDENTIFICATION: MANUFACTURER

PureShield Inc.

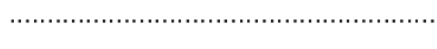

info@puremaintenance.com

EMERGENCY PHONE NUMBER ....InfoTrac 800-535-5053 (day/night)

PRODUCT NAME

CHEMICAL FAMILY .............................. Organosilane

EPA Registration \# ........................... 87583-2

Last Revision Date ........................... $7 / 8 / 2011$

II. PHYSICAL DATA

BOILING POINT ................ > $>210^{\circ} \mathrm{F} \quad$ SOLUBILITY (WATER) ...... Soluble

VAPOR PRESSURE …........ N/A ODOR …................... Mild

VAPOR DENSITY .............. N/A APPEARANCE ............... Clear liquid

$\%$ VOLATILES..................... ND EVAPORATION RATE ...... (water $=1)$

$\mathrm{pH}$ of PRODUCT ................. approx 5.0 SPECIFIC GRAVITY ........ 1.003

III. CHEMICAL COMPONENTS

$\begin{array}{lcccc}\text { COMPONENT } & \text { C.A.S.\# } & \text { HAZARD } & \text { from\% - to \% } & \frac{\text { T.L.V. }}{\text { Irritant }} \\ \begin{array}{l}\text { 3-(Trimethoxysilyl) } \\ \text { propyldimethyloctadecyl ammonium }\end{array} & 27668-52-6 & 5.00 \% & \text { None }\end{array}$

propyldimethyloctadecyl ammonium

IV. FIRE AND EXPLOSION DATA

FLASH POINT ('F) ............... N/A

FLAMMABLE LIMITS: $\quad$ (upper) N/A (lower) N/A

EXTINGUISHING MEDIA .. Dry chemicals, foam, carbon dioxide, water spray.

SPECIAL FIRE-FIGHTING PROCEDURES .... Must be equipped with self contained breathing apparatus.

UNUSUAL FIRE AND EXPLOSION HAZARDS... None Must be equipped with self contained breathing apparatus.
Cool heated drums with water spray to prevent bursting.

\section{HEALTH HAZARD DATA}

Harmful if swallowed, inhaled or absorbed through the skin.

TLV ............... NO ACGIH TLV PUBLISHED PEL.......... NO OSHA PEL PUBLISHED

EYES ............ Prolonged contact may cause irritation.

SKIN ............. Prolonged contact may cause irritation.

INHALATION Harmful if inhaled.

INGESTION.. Harmful if swallowed.

EFFECTS OF OVEREXPOSURE...Not known $* * * * * * * * * * * * * * * * * * * * * * * * *$ FIRST AID $* * * * * * * * * * * * * * * * * * * * * * * * *$

EYES: Flush with plenty of water for at least 15 minutes. If irritation persists, get medical attention.

SKIN: Remove clothing if necessary, rinse skin, if irritation persists get medical attention. 
INHALATION: Remove to fresh air. If not breathing, Call 911 and then give artificial respiration.

INGESTION: Do not induce vomiting. Call a poison control center or doctor immediately for treatment advice. Have the person sip a glass of water if able to swallow. Do not give anything to an unconscious person.

In all cases call Poison Control Center or Doctor for treatment advice.

\author{
VI. REACTIVITY DATA \\ STABILITY ........................ STABLE \\ CONDITIONS TO AVOID .... Do not mix with cleaners, do not freeze, and avoid heat. \\ INCOMPATIBILITY............... Sodium oxidizers \\ HAZARDOUS DECOMPOSITION PRODUCTS: \\ HAZARDOUS POLYMERIZATION: WILL NOT OCCUR \\ CONDITIONS TO AVOID:
}

VII. SPILL OR LEAK PROCEDURES

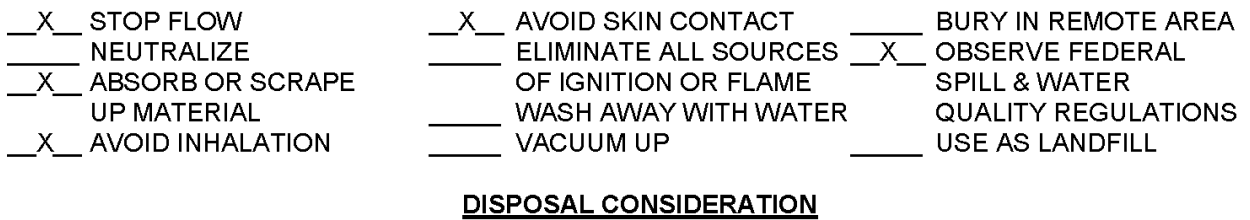

Product/Soil/Water maybe subject to RCRA/OSHA hazardous waste. Landfill solids at permitted sites.

Follow all federal, state and local waste management regulations.. Where permissible, consider discharge to TW, biological treatment, or incineration.

To inactivate product, add anionic surface or detergent in equal amount to the product.

\title{
VIII. SPECIAL PROTECTION INFORMATION
}

RESPIRATORY................. Utilize respiratory equipment in accordance to 29 CFR1910.134 if other SKIN ............................... Rubber or plastic gloves

EYES ............................... To avoid eye contact wear goggles

VENTILATION ........................ X_General Ventilation Local Exhaust

OTHER PROTECTION Consider long sleeves, long pants, and apron. Eye wash and safety shower should be in area of use.

IX. SPECIAL PRECAUTION

No special precautions beyond routine prudent safe handling of chemical substances are necessary.

X. REGULATORY INFORMATION

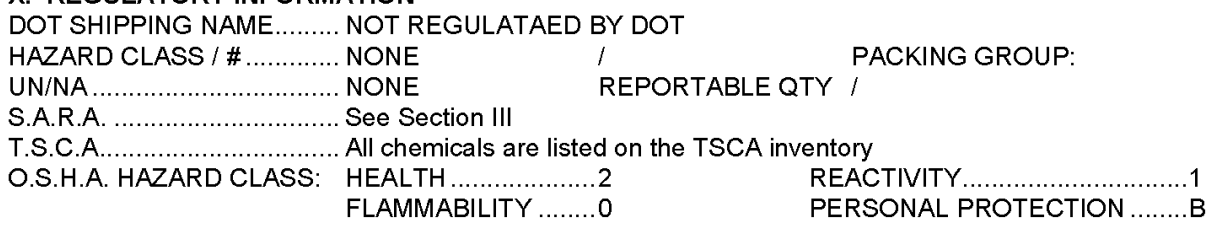

\section{MISCELLANEOUS}

COMPANY CONTACT: Dan Hill

This Material Safety Data Sheet has been prepared in compliance with the 29CFR 1910.1200. The information contained herein is prepared by qualified personnel at Hill Chemical and we believe that the information contained is accurate and current as of the date of preparation; however, no warranty, expressed or implied is given regarding the accuracy of the data or the results to be obtained from the use thereof. Since the use of this information and the conditions of use of this product are beyond our control, Hill Chemical. assumes no liability for injuries or damages associated with the use or the product described herein. It is the user's responsibility to ensure that his activities comply with applicable federal, state or provincial, and local laws. 


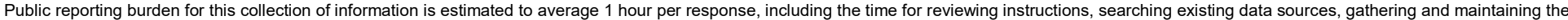

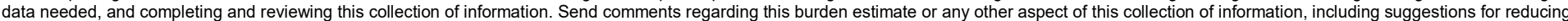

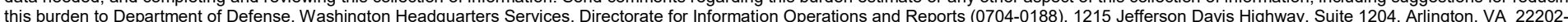

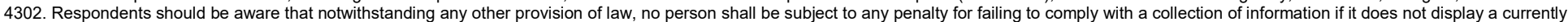
valid OMB control number. PLEASE DO NOT RETURN YOUR FORM TO THE ABOVE ADDRESS.
1. REPORT DATE (DD-MM-YYYY)
2. REPORT TYPE
Final

\section{TITLE AND SUBTITLE}

$08 / 20 / 2018$

Performance Testing of a Novel Dry-Fog Mold Remediation and Prevention Process

6. AUTHOR(S)

Shane D. Hirschi and Dale L. Herron
3. DATES COVERED (From - To)

5a. CONTRACT NUMBER

5b. GRANT NUMBER

5c. PROGRAM ELEMENT

5d. PROJECT NUMBER

ITTP

5e. TASK NUMBER

5f. WORK UNIT NUMBER

8. PERFORMING ORGANIZATION REPORT NUMBER

ERDC/CERL TR-18-17

S. Army Engineer Research and Development Center (ERDC)

Construction Engineering Research Laboratory (CERL)

PO Box 9005

Champaign, IL 61826-9005

\section{SPONSORING / MONITORING AGENCY NAME(S) AND ADDRESS(ES)}

Assistant Chief of Staff for Installation Management (ACSIM)

600 Army Pentagon

Washington, DC 20310-0600

10. SPONSOR/MONITOR'S ACRONYM(S)

ACSIM

11. SPONSOR/MONITOR'S REPORT NUMBER(S)

\section{DISTRIBUTION / AVAILABILITY STATEMENT}

Approved for public release; distribution is unlimited.

\section{SUPPLEMENTARY NOTES}

\section{ABSTRACT}

Mold is an ongoing problem for Army installations and contingency basing locations. This work was undertaken to demonstrate the effectiveness of a two-step dry-fog mold remediation process technology to remove mold spores and provide long-term mold prevention in two buildings at Fort Campbell, KY. Treating each test building took 5 to 6 hours and included: mobilization, air and surface sampling before and after the application, and demobilization. This work concluded that the dry-fog technology provides rapid and quantifiable improvements to indoor air quality, and reduces exposure of personnel to harmful chemicals resulting from current mold remediation practices. Results indicated that the dry-fog technology could potentially support mold remediation needs resulting from indoor air quality maintenance and from natural hazards. Current rough estimates for application of the dry-fog technology are approximately $\$ 1.00 / \mathrm{sq} \mathrm{ft}$. Early project results were shared with Region IV of the Federal Emergency Management Agency (FEMA) and the Huntington District of the U.S. Army's Corps of Engineers.

\section{SUBJECT TERMS}

Molds (Fungi)-Control, Indoor air quality, Indoor air pollution-Research, Military bases, Buildings

\section{SECURITY CLASSIFICATION OF:}

a. REPORT
Unclassified

NSN 7540-01-280-5500

17. LIMITATION
OF ABSTRACT
SAR

18. NUMBER OF PAGES

\begin{tabular}{|c|c}
\hline b. ABSTRACT & c. THIS PAGE \\
Unclassified & Unclassified
\end{tabular}

89 19a. NAME OF RESPONSIBLE PERSON

19b. TELEPHONE NUMBER

(include area code) 